\title{
O MUNDO INVISÍVEL cosmologia, sistema ritual e noção de pessoa no espiritismo
}

Maria Laura Viveiros de Castro Cavalcanti 


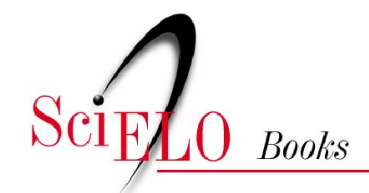

\section{O mundo invisível}

cosmologia, sistema ritual e noção de pessoa no espiritismo

\section{Maria Laura Viveiros de Castro Cavalcanti}

CAVALCANTI, MLVC. O mundo invisivel: cosmologia, sistema ritual e noção de pessoa no espiritismo [online]. Rio de Janeiro: Centro Edelstein de Pesquisa Social, 2008. 133 p. ISBN 978-8599662-27-4. Available from SciELO Books <http://books.scielo.org $>$.

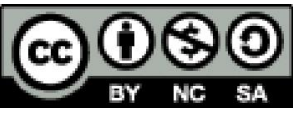

All the contents of this chapter, except where otherwise noted, is licensed under a Creative Commons Attribution-Non Commercial-ShareAlike 3.0 Unported.

Todo o conteúdo deste capítulo, exceto quando houver ressalva, é publicado sob a licença Creative Commons Atribuição Uso Não Comercial - Partilha nos Mesmos Termos 3.0 Não adaptada.

Todo el contenido de este capítulo, excepto donde se indique lo contrario, está bajo licencia de la licencia Creative Commons Reconocimento-NoComercial-CompartirIgual 3.0 Unported. 
Esta publicação é parte da Biblioteca Virtual de Ciências Humanas do Centro Edelstein de Pesquisas Sociais www.bvce.org

Copyright (c) 2008, Maria Laura Viveiros de Castro Cavalcanti

Copyright (c) 2008 desta edição on-line: Centro Edelstein de Pesquisas Sociais.

Ano da última edição: 1983

Nenhuma parte desta publicação pode ser reproduzida ou transmitida por qualquer meio de comunicação para uso comercial sem a permissão escrita dos proprietários dos direitos autorais. A publicação ou partes dela podem ser reproduzidas para propósito não-comercial na medida em que a origem da publicação, assim como seus autores, seja reconhecida.

ISBN 978-85-99662-27-4

Centro Edelstein de Pesquisas Sociais www.centroedelstein.org.br

Rua Visconde de Pirajá, 330/1205

Ipanema - Rio de Janeiro - RJ

CEP: 22410-000. Brasil

Contato: bvce@centroedelstein.org.br 
Índice

Apresentação

capítulo I

UM ESTUDO DO ESPIRITISMO A PARTIR DE GRUPOS ESPECÍFICOS

1. O Espiritismo e suas Fronteiras Externas $\quad 7$

2. O Trabalho de campo

O lar de Tereza, 11; O Instituto Brasileiro de Cultura Espírita , 12

A Literatura Espírita, 13

3. O Racional e o Místico

4. O Movimento Espírita

\section{capítulo II}

A COSMOLOGIA ESPÍRITA

1. A Religião como Sistema de Representação e Práticas 23

2. A cosmologia Espírita $\quad 27$

O Mundo Visível e o Mundo Invisível, 27; A Evolução, o Progresso e o

Desenvolvimento das Desigualdades entre Espíritos, 28; A Encarnação, o Carma, 33

3. A noção de Pessoa no eixo da Diacronia

capítulo III

O CENTRO E O SISTEMA RITUAL ESPÍRITA

1. O centro Espírita

A Hierarquia de Potencial, 47; A classificação dos Agentes Rituais, 50

2. O Sistema Ritual Espírita

A Mediunidade, o Estudo e a Caridade, 53; A Caridade, 55;

O Estudo, 62

\section{capítulo IV}

A MEDIUNIDADE

1. Mediunidade, Transe e Possessão 70

2. A Mediunidade como Dom e Exercício

$\begin{array}{ll}\text { 3. A Comunicação Espiritual } & 78\end{array}$

A Obsessão, 81

4. A comunicação Espírita $\quad 85$

O Médium, 85; As Formas de Comunicação Espírita, 90 


\section{APRESENTAÇÃO}

O Espiritismo, ressalvada a contribuição de alguns autores (ver o capítulo I), tem recebido pouca atenção dos estudiosos da religião. Concorrendo com os "traços espíritas" para o "sincretismo" que teria dado origem às religiões afro-brasileiras ${ }^{1}$, e tendo em comum com estas a crença em Espíritos e a mediunidade - a afirmação da relação entre homens e Espíritos -, sua particularidade é dificilmente percebida.

Este livro propõe-se a estudar o Espiritismo como um sistema religioso, um sistema de crenças e práticas que se inclui no quadro maior de religiões mediúnicas. Com base na seleção de grupos específicos, seu objetivo central é a apreensão e discussão das categorias e representações que constituem essa experiência religiosa e dos valores culturais a ela relacionados. Nessa perspectiva a percepção da construção da noção de pessoa no Espiritismo se apresenta como um fio condutor e como uma pista particularmente esclarecedora da experiência do transe e da mediunidade nessa religião.

Desde Durkheim os estudos antropológicos sobre religião indagam-se sobre a relação que esta mantém com a sociedade. Gostaria de dizer algumas palavras acerca da maneira pela qual essa relação é pensada aqui.

A dicotomia que se estabelece entre a religião e sociedade tem o perigo de fazer-nos tomar o religioso e o social como realidades excludentes que implicam a percepção dos sistemas religiosos como expressões ou traduções de outras realidades mais básicas - a trajetória de vida, a posição de classe, a rede social e, em suma, a estrutura e organizações sociais mais abrangentes. A perspectiva que esse trabalho adota é a de que o social se constitui da particularidade dos aspectos sob os quais o apreendemos (o jurídico, o político, o religioso, o econômico etc.), da articulação desses múltiplos planos, cada um dos quais possui sua especificidade (Mauss, 1978 e Lévi-Strauss, 1976). Assim, de um lado, o "religioso" é em si mesmo "social" e, de outro, a reflexão sobre a inter-relação entre o religioso e os outros domínios sociais supõe a apreensão da particularidade desse primeiro domínio.

Evidentemente uma religião existe no mundo, é influenciada por eles e seus adeptos, no seu dia-a-dia, atravessam diversos domínios da sociedade. Este trabalho enfatiza contudo o fato de que religião não apenas "expressa" ou "traduz" outras realidades, como é também uma matriz de produção de valores, de maneiras de pensar e se relacionar com a realidade social mais abrangente (Geertz, 1980 e Weber, 1967). ${ }^{2}$ Sem pretender negar a importância de um estudo que reflita

\footnotetext{
${ }^{1}$ Para a discussão crítica da noção de sincretismo, ver Velho, Y., 1945 e Birman 1980.

${ }^{2}$ Para um trabalho que adota um ponto de vista semelhante, ver Goldman, Márcio,1982 (mimeog.)
} 
especificamente sobre a articulação entre o Espiritismo e a sociedade brasileira, este estudo pretende apreender a particularidade do sistema religioso espírita enquanto tal. Sua tentativa é perceber no Espiritismo a construção de uma determinada matriz de leitura e experiência do social. Nesse movimento sugerem-se algumas pistas para a reflexão acerca da maneira pela qual esse sistema articula com a realidade social envolvente.

O primeiro capítulo procura demarcar o objeto da pesquisa em vários planos. Discuto inicialmente a questão dos limites do Espiritismo como um sistema próprio a partir da literatura existente sobre o assunto, formulando nesse contexto minha opção de pesquisa. Apresento o trabalho de campo e o universo social pesquisado. Examino algumas características e conceitos básicos do Espiritismo, bem como a interpretação que estudiosos do assunto conferiram a eles. Apresento finalmente o Movimento Espírita, indicando sua complexidade e situando os grupos pesquisados em seu interior.

O segundo capítulo define a perspectiva teórica e metodológica adotada e analisa os princípios centrais da cosmologia espírita.

O terceiro capítulo procede a uma breve etnografia do centro espírita pesquisado. Inicia também a discussão do sistema ritual espírita, através do exame da classificação dos agentes rituais no centro e de três categorias com os quais os espíritas distinguem as diferentes sessões que realizam: a mediunidade, o estudo e a caridade.

O quarto capítulo detém-se na análise da mediunidade. Sua proposta é ver a experiência da mediunidade e do transe no Espiritismo a partir da concepção da pessoa nessa religião. Discuto parte da literatura antropológica que aborda o transe e a possessão. Examino a seguir as concepções da mediunidade como dom e exercício, a comunicação espiritual e a comunicação espírita.

As conclusões retomam a questão da relação entre Espiritismo e Umbanda e a representação espírita da pessoa.

Gostaria de agradecer a todos aqueles que contribuíram de maneiras diversas para a realização desta pesquisa.

Minha participação como aluna do PPGAS foi possível graças a uma bolsa de estudos concedida pelo CNPq. Parte da pesquisa e sua redação tornaram-se viáveis graças ao financiamento da Fundação Ford. Agradeço a ambas as instituições o crédito me concederam.

Muitas pessoas concorreram para despertar meu interesse não só pela Antropologia como pela religião e pelo tema específico aqui tratado. Agradeço sobretudo aos professores Luiz Fernando Dias Duarte, Luiz Tarlei de Aragão, Roberto Da Matta, Eduardo Viveiros de Castro, Yvonne Maggie, Rubem César Fernandes, com quem tive a oportunidade de discutir ao longo período de elaboração e realização da pesquisa. Suas sugestões foram de valor inestimável. Agradeço 
especialmente aos professores Gilberto Velho e Anthony Seeger, meus orientadores em momentos distintos do mestrado. Ao professor Gilberto Velho agradeço as contribuições, a amizade com que acompanhou este trabalho, bem como o convite para sua publicação. Ao professor Anthony Seeger sua sensibilidade e lúcidas sugestões. Ao professor Peter Fry, membro de minha banca, sou grata por suas críticas e seu incentivo.

Algumas idéias aqui desenvolvidas foram apresentadas em comunicações no $\mathrm{V}$ Encontro Anual da Associação de Pós -Graduação e Pesquisa em Ciências Sociais no Grupo "Ideologia e Cultura Popular", e na XIII Reunião Nacional de Antropologia na mesa- redonda "Sistemas Cognitivos em Perspectiva Comparada", coordenada pelos professores Ruth Cardoso e Gilberto Velho. Agradeço aos participantes das discussões a oportunidade de reflexão.

Aos colegas e amigos Miriam e Márcio sou grata pela leitura dos rascunhos e por suas sugestões. A eles e a Ricardo, Silvana, Bruna e Malu agradeço o interesse pelo meu trabalho bem como a solidariedade e paciência com que escutaram minhas lamúrias e alegrias.

A Marisa, o cuidadoso trabalho de datilografia dos originais.

Aos espíritas, a tolerância e solicitude com que sempre me receberam. Aqueles que porventura lerem este livro terão muitos reparos a fazer. A eles apresento desculpas pelas limitações e imperfeições de minha interpretação de sua vivencia religiosa. Ao professor Deolindo Amorim agradeço a leitura deste trabalho bem como seus comentários.

A meus pais, o carinho e o apoio financeiro que possibilitou minha dedicação à pesquisa e à redação.

Ao Ovídio, a sua presença. 
capítulo I

\section{UM ESTUDO DO ESPIRITISMO A PARTIR DE GRUPOS ESPECÍFICOS}

Na definição do objeto deste livro - o estudo do Espiritismo como um sistema religioso a partir da seleção de grupos específicos - emergem como relevantes quatro questões preliminares em torno das quais este capítulo se organiza. Duas delas provêm do exame da literatura sociológica sobre o tema: a das fronteiras do Espiritismo e de suas relações com a Umbanda, e a da caracterização do Espiritismo a partir da interpretação de alguns de seus traços centrais. As duas outras remetem ao contexto da pesquisa. São elas: a da própria seleção dos grupos pesquisados, do trabalho de campo, e a da complexidade do Movimento Espírita no qual esses grupos se situam. As duas primeiras serão tratadas respectivamente nos itens 1 e 3 . As duas últimas nos itens 2 e 4 .

\section{O Espiritismo e suas Fronteiras Externas}

Espiritismo é um termo imprecisamente definido na literatura sociológica, comportando significações diversas. Diana Brown (Brown, 1974: cap. I) refere-se ao fato de o termo Espiritismo no Brasil ser

usado geralmente como incluindo várias seitas religiosas, das quais as maiores e mais conhecidas seriam o Kardecismo, as seitas afro - brasileiras e a Umbanda.

Todas têm comum

uma crença nos espíritos e a aceitação da possessão como o meio pelo qual os espíritos se comunicam com os vivos.

A autora define então a Umbanda como

a forma mais popular do Espiritismo, combinando elementos das duas outras tradições.

Donald Warren Jr. (Warren JR., 1968: 3) fala do rápido crescimento do Espiritismo no Brasil em suas duas modalidades:

na sua forma "baixa", a Umbanda, cuja origem parece derivar da religião animista dos escravos transportados para a África; e na sua forma "elevada", o Kardecismo, da filosofia reencarnacionista importada da França um século atrás.

Parke Renshaw (Renshaw, 1969) utiliza o termo Espiritismo para designar a religião codificada por Allan Kardec. Todavia, o mesmo autor, num artigo posterior (Renshaw, 1975: 8), define seu interesse como recaindo sobretudo no "Espiritismo de Kardec" e na "Umbanda" e, por tabela, no "Baixo Espiritismo e Candomblés da Bahia". Terminando por reunir as religiões estudadas em sua proposta de perceber 
os Espiritismos no quadro geral de urbanização, industrialização e manutenção do statu quo.

Essas formulações sugerem a leitura do Kardecismo, da Umbanda e das demais religiões "afro-brasileiras" como formas diversas de uma religião maior, o Espiritismo, apontando a velha questão do sincretismo religioso (Bastide, 1971; Nina Rodrigues, 1900).

Apesar de sua obra ser anterior aos trabalhos mencionados, Candido Procópio Camargo, tomando a Umbanda e o Kardecismo como focos, formula de maneira mais precisa o problema que subjaz a essa confusão na terminologia. Camargo fala no "Espiritismo kardecista", ou simplesmente no "Kardecismo", e na "Umbanda" como religiões

que apresentam traços significativos e experiências religiosas comuns que as englobam em uma mesma unidade, constituindo o fenômeno mediúnico o traço fundamental (Camargo, 1973: 159).

A partir dessa visão o autor propõe sua tese do "continuum mediúnico": Kardecismo e Umbanda devem ser vistos como pontos extremos de um gradiente diferenciado em seu interior pelo "grau de simbiose doutrinária e ritualística". Ao Kardecismo correspondem a mediunidade consciente, a predominância de formulações éticas de inspiração cristã, a sobriedade. À Umbanda, a mediunidade inconsciente, a ênfase no cumprimento de preceitos ritualísticos, a introdução de elementos mágicos e a emocionalidade (Camargo, op. cit.: 167). O continuum, segundo o autor, se constitui num

fato social, existindo independentemente do direito a distinções e separações rígidas feitas pelos fiéis (Camargo, 1961: xiv).

A mediunidade, a relação com Espíritos, é aí eleita como central, servindo de base à construção do continuum.

A problematização da relação entre Kardecismo e Umbanda está também presente nos autores acima mencionados. Em sua análise da Umbanda, Diana Brown (Brown, op. cit.) vê o Kardecismo como uma referência central. Warren Jr. (Warren Jr., 1968b: 393-405) afirma que o Kardecismo e a Umbanda são doutrinas não-fechadas e indica a possibilidade de a distinção entre as duas formas religiosas estar se apagando. Pressel (Pressel, 1974: 116) diz ter encontrado, na visita a 12 centros na cidade de São Paulo, a confirmação do continuum de Camargo.

Se os atributos que definem os extremos do "continuum mediúnico" proposto por Camargo são certamente etnocêntricos (Kardecismo = consciência, sobriedade, ética e Umbanda = inconsciência, ritualismo e magia), o autor aponta com sua formulação uma questão importante e que gostaria de reter: a da relação entre os dois sistemas religiosos mencionados e o lugar da experiência da mediunidade nessa relação. 
Os grupos religiosos com que entrei em contato definem-se como espíritas. ${ }^{1}$ Adotando como referência doutrinária básica as obras codificadas por Allan Kardec, esses grupos vêem o Espiritismo como distinto de "outras formas de Espiritualismo". ${ }^{2}$

Se a maioria dos estudiosos do assunto enfatiza a relação ou continuidade entre Espiritismo e Umbanda, os grupos que pesquisei, definidos pela frequiência a determinadas instituições e pelo partilhar da mesma crença, ${ }^{3}$ estão pelo contrário extremamente preocupados em demarcar as fronteiras de sua religião com relação às demais e, em especial, a Umbanda.

Adotei como ponto de partida de minha pesquisa essa visão dos grupos sobre si mesmos. Minha proposta é estudar o Espiritismo como um sistema religioso próprio. Esse é o bias inicial, que não significa contudo o abandono da questão de suas fronteiras. Meu procedimento será, em certo sentido, inverso ao dos autores mencionados. Assumindo a definição de realidade dos grupos estudados, a sua "subjetividade", parto da afirmação do caráter distintivo do Espiritismo como religião para recolocar, ao final, o problema de suas fronteiras e relações com as demais religiões. Essa questão constitui-se em pano de fundo de toda a discussão. $\mathrm{O}$ fato de esses grupos estarem permanentemente preocupados com a demarcação dos limites de sua religião é indício de que sua identidade (como toda identidade) não se constrói, sem problemas, da multiplicidade de classificações de que são objeto, de uma ambigüidade que é por eles manipulada.

\section{O Trabalho de Campo}

Meu trabalho de campo teve três focos: um centro espírita, o Lar de Tereza, localizado em Ipanema; uma instituição espírita que se define como cultural, o Instituto de Cultura Espírita do Brasil (ICEB), que, não dispondo de sede própria, funciona no auditório da Federação Espírita do Rio de Janeiro (FEERJ) na Lapa; e literatura espírita.

Cheguei ao Lar de Tereza através de uma amiga de minha mãe, antiga conhecida minha, que o freqüentara e mantinha relações de amizade com vários de seus freqüentadores. Ela e suas amigas iam também semanalmente ao ICEB, e tinham em alta conta seu presidente. Por "coincidência", um amigo meu era grande amigo do filho do presidente do ICEB e ofereceu-se para apresentar-me a

\footnotetext{
${ }^{1}$ No contexto da pesquisa a denominação kardecista era empregada sobretudo por membros de outras religiões, e algumas vezes por espíritas para se distinguirem de outros grupos religiosos. A designação Espiritismo era a mais freqüente e tida pelos espíritas como a correta. Como me disse um espírita: "Kardecismo dá a idéia de uma seita, fundada por um homem, quando o Espiritismo não é isso. A doutrina não é de Kardec, é dos Espíritos."

${ }^{2}$ É Kardec quem, na "Introdução do Estudo da Doutrina Espírita", no Livro dos Espíritos, propõe a distinção entre a noção de Espiritualismo - "qualquer um que acredite que há em si mesmo alguma coisa além da matéria é espiritualista" - e Espiritismo, uma das fases do Espiritualismo - "a crença na existência de Espíritos e em sua comunicação com o Mundo Visível". Para uma elaboração dessa distinção, ver Amorim, O Espiritismo e as Doutrinas Espiritualistas, Livraria Chignone Ed.

${ }^{3}$ Para uma discussão do conceito de grupo, ver Velho, Gilberto, 1975.
} 
ele. Cheguei assim ao ICEB. Os objetivos da pesquisa levaram-me posteriormente, e de maneira esporádica, a dois outros centros espíritas: O Grupo Espírita André Luiz (GEAL), localizado na Tijuca, que visitei sete vezes, e o Templo Espírita Tupyara, localizado no Lins, ao qual fui duas vezes. Cheguei ao André Luiz através da mãe de uma amiga e, conhecendo o Tupyara através do trabalho da Zélia Milanez Lossio (Lossio, 1979), lá fui por conta própria.

A proximidade social do universo a ser pesquisado estava assim, desde o início, bastante evidente. No decorrer da pesquisa fui descobrindo vários amigos cujos pais eram espíritas, os quais tinham conhecidos espíritas ou mesmo que o haviam sido quando crianças. Por outro lado, encontrava por vezes em bares, cinemas, cabeleireiros e farmácias que freqüentava, pessoas a quem havia conhecido através da pesquisa. Nos grupos pesquisados a maior parte das pessoas morava na zona sul do Rio de Janeiro, ${ }^{4}$ algumas haviam cursado a universidade e entendiam do que se tratava quando eu me apresentava como "pesquisando para minha dissertação de mestrado".

Os autores que trabalharam com o Espiritismo são unânimes em localizar os adeptos dessa religião na chamada classe média (Renshaw, Camargo, Brown, op. cit.). Usando como critério a maneira de comportar-se, de vestir-se, de falar, o tipo de linguagem, os bens de consumo usados, o local de moradia e as profissões ou atividades a que se dedicam (funcionários públicos, profissionais liberais, artistas, estudantes, militares, donas-de-casa), os espíritas pertencem sem dúvida a um universo social de camadas médias, constituído de pessoas em sua maioria brancas. De tudo isso, advinha uma certa "familiaridade" com o meu objeto de pesquisa.

A especificidade do trabalho de campo em antropologia, e do trabalho de campo no contexto urbano, em uma sociedade complexa, tem sido discutida por diversos autores (Da Matta, 1978 e Gilberto Velho, 1980, 1981). Gilberto Velho chama atenção para o fato de o familiar não ser necessariamente conhecido ou o exótico necessariamente desconhecido. Sem dúvida, a experiência religiosa (como outras experiências sociais), definindo ethos e visões de mundo particulares (Geertz, 1978), constrói fronteiras simbólicas entre grupos e camadas de uma mesma sociedade (Velho, 1981:16).

No meu caso, essa familiaridade percebida não era mais, por assim dizer, do que uma proximidade "profana", encobrindo a crença em um sistema religioso que me era desconhecido. $\mathrm{Na}$ verdade, não o era totalmente, no sentido em que minha visão do Espiritismo se tenha inaugurado

\footnotetext{
${ }^{4}$ No Rio de Janeiro, a oposição entre a zona sul e a zona norte da cidade é bastante nítida. A zona sul é a parte da cidade onde se concentram os serviços urbanos e o consumo em geral. A zona norte define-se por uma relação de carência com relação a essas coisas. Pode-se perceber também, em termos gerais, diferenças de ethos entre as duas. A zona sul se caracteriza por seu cosmopolitismo e a zona norte por um ethos mais tradicional. Ver a esse respeito Gilberto Velho, 1975. Estou usando o conceito de ethos no sentido em que Bateson o define, como um sistema culturalmente padronizado de produção e organização de emoções (Bateson, 1965).
} 
simultaneamente ao meu interesse antropológico pelo tema. Ao chegar ao centro, e mesmo ao instituto, minha visão do Espiritismo estava carregada de preconceitos, imagens e temores que talvez sejam comuns àqueles que, como eu, tiveram um passado católico. Lembrava-me de histórias - ouvidas na escola - de copos que andam, cadáveres que se levantam, objetos que se movimentam inesperadamente, tudo "coisas do demônio". Como num jogo, contudo, conforme as regras desse sistema iam se tornando claras para mim, essas imagens e temores foram se dissipando. Essa aparente familiaridade ia se transformando em estranheza e em algum conhecimento da maneira de ser e de pensar daquelas pessoas numa dimensão importante de suas vidas.

\subsection{O Lar de Tereza}

A pesquisa no Lar de Tereza realizou-se durante o ano de 1980, basicamente de março a outubro, e foi retomada posteriormente de abril a junho de 1981. Pode ser dividida em duas fases. A primeira delas, de março a junho de 1980, em que assisti às sessões que não lidavam explicitamente com a mediunidade. O transe no Espiritismo é, como veremos, cercado de cuidados e controles. Assim, na medida em que

o Mediunismo não é o Espiritismo, que é uma doutrina com princípios (...) (frase de uma informante), julgava-se conveniente que eu começasse por aí. Era também o tempo necessário para que se avaliasse a "seriedade do meu trabalho", se era "simples curiosidade ou se tratava de um interesse genuíno". Todavia, na medida também em que

Não existe Espiritismo sem Mediunismo (frase de outra informante),

obtive no mês de julho autorização da presidente do centro para assistir às sessões que lidam de maneira explícita com a mediunidade ${ }^{5}$.

Um centro é por definição um lugar aberto ao mundo, é o "dinamismo da caridade em ação". 6 Os espíritas estão lá entre outras coisas porque "têm muito amor para dar". Nesse contexto, como todos os que batem às suas portas, eu era sempre bem recebida, embora de maneira impessoal. Minha intenção de pesquisar o Espiritismo "puro" coincidia com as preocupações do grupo de afirmação de sua religião. Esse fato fazia com que minha presença nas sessões fosse de modo geral bem aceita, embora nem por isso menos ambígua.

Nas reuniões abertas ao público, que não lidam expressamente com a mediunidade, o comportamento dos médiuns e organizadores das sessões enfatiza a "disciplina, o recolhimento, a

\footnotetext{
${ }^{5}$ Ver a esse respeito o capítulo III.

${ }^{6}$ Ver O Mundo Espírita, janeiro de 1980.
} 
conversa tranqüila". Embora seja esse, via de regra, o comportamento adequado para o interior do centro, nas reuniões mais restritas, mediúnicas, pelo próprio fato de os participantes se conhecerem mais intimamente, o ambiente torna-se mais informal e descontraído. Nesses momentos, bem como nas viagens de visita às obras assistenciais e saídas de sessões noturnas, tive oportunidade de convívio e conversa informal com os espíritas. Conforme o caminho da pesquisa ia sendo percorrido, tornava-me familiar às organizadoras do centro, e a relação, cada vez mais pessoal, acentuava a ambigüidade da minha situação. Perguntavam-me pela pesquisa, por minhas filhas, e por quando iria começar a desenvolver. Meu nome era incluído na lista de presença dos médiuns, meu auxilio era solicitado para algumas tarefas. A vivência dessa ambigüidade culminou quando freqüentei com uma turma de médiuns em desenvolvimento um "curso de passes". A última aula do curso consistia na prática do passe e tinha o caráter de uma iniciação: os médiuns passariam daquele momento em diante a dar passes nas diversas sessões do centro.

Eu, que estava "apenas assistindo", não pude deixar de "participar". Ao final vários médiuns brincaram comigo e a dirigente do curso comentou: "Não é problema, mesmo sem ser espírita você tem fluidos. É um treinamento seu." Naquele momento percebi que, de certo modo, eu estava também me "tornando espírita", no sentido em que aprendia a me mover nessa religião, a interpretar sonhos e pensamentos, a experimentar sentimentos e emoções, a dar passes como meus colegas médiuns.

Todavia, o respeito à opção, ao livre-arbítrio individual (ver capítulo II) mantinha as expectativas no sentido de minha adesão sob controle. Ao final do trabalho, definindo-se finalmente minha identidade de pesquisadora, a diretora de um dos departamentos perguntou-me se eu havia chegado a conclusões válidas, não de seu ponto de vista mas do meu. ${ }^{7}$

\subsection{O Instituto Brasileiro de Cultura Espírita}

Dado o caráter particular do ICEB, que define seus objetivos como "o estudo, difusão e defesa dos princípios espíritas" e circunscreve suas atividades ao "âmbito cultural do Movimento Espírita" 8 a pesquisa nessa instituição ganhou outra feição.

O Instituto de Cultura Espírita do Brasil promove ciclos trienais de palestras e conferências. Suas atividades inauguram-se em março, interrompem-se durante o mês de julho, quando se realizam mesas-redondas e debates, e prosseguem até o final de novembro. Seu corpo de expositores compõe-se de oito membros, reunindo alguns dos intelectuais espíritas de renome no

\footnotetext{
${ }^{7}$ Para uma comparação da maneira pela qual os diferentes sistemas religiosos se relacionam com e classificam a personagem do pesquisador, ver Lossio, 1980.

${ }^{8}$ Anais do Instituto de Cultura Espírita Brasileira, vol. III, p. 1.
} 
Rio de Janeiro. ${ }^{9}$ Muitos viajam constantemente para debates e conferências em outras cidades do Brasil. Alguns possuem livros publicados (obras não-mediúnicas) e escrevem regularmente em jornais espíritas. Cada expositor é especialista em uma "matéria". Durante o ano de 1980 as matérias eram as seguintes: Doutrina Espírita, Mediunidade e os Fatores Genéticos, Reencarnação e Personalidade, Doutrina Espírita e Moral Cristã, Influências do Pensamento Espírita, Evolução e Espírito, Problemas de Direito na Doutrina Espírita, o Inconsciente e os Conhecimentos Acumulados. Os expositores dividem-se em pares que falam em sábados fixos do mês (quando o mês tem cinco semanas, no último sábado passam-se filmes, organizam-se debates etc.). Em cada palestra desenvolvem-se aspectos desses temas maiores. O trabalho de campo no ICEB consistiu basicamente na freqüência ao ciclo de palestras realizado no ano de 1980. Encontrava geralmente lá pessoas do Lar de Tereza, com quem tomava café e por vezes voltava para casa.

O caráter "racional" do Espiritismo, que na prática religiosa dos centros se traduz na valorização da fala, da leitura e do estudo ganha no ICEB uma de suas expressões mais acabadas. Se desde a leitura dos Azande de Evans-Pritchard (Evans-Pritchard, 1972) eu estava atenta para procurar na religião critérios de racionalidade outros que não os "científicos", com relação ao ICEB, a minha proximidade de outras falas, leituras e estudos constituiu-se por vezes em impedimento para a compreensão da prática em questão. Buscava nas palestras escutadas, mesmo sem o querer, um nexo cujos parâmetros estavam dados pelo conhecimento e pelos procedimentos acadêmicos. Foi apenas quando me dei plena conta do caráter igualmente ritual destes últimos que a experiência de pesquisa no ICEB tornou-se menos opaca.

Como ocorreu no Lar de Tereza, aqui também minha intenção de pesquisar o Espiritismo "puro" coincidia com as preocupações do grupo, contribuindo para a boa aceitação de minha presença.

\subsection{A Literatura Espírita}

Antes de iniciar a pesquisa nos locais acima mencionados, eu havia lido o Livro dos Espíritos. Como pude comprovar logo em seguida, essa leitura era de fato fundamental. Ela não só facilitou a compreensão desse sistema como me era sugerida por todos os espíritas com quem conversava, que a consideravam básica para todo e qualquer espírita e para alguém que se propunha a pesquisar o Espiritismo. O Espiritismo é uma religião letrada, codificada. O livro, a leitura, o estudo ocupam, como veremos, um lugar importante no seu sistema ritual (ver o capítulo III). De um lado, diferentemente do que ocorre com a Umbanda, por exemplo, esse fato torna mais fácil o

\footnotetext{
${ }^{9}$ Ver, para maior detalhe, o capítulo III.
} 
reconhecimento de sua unidade. De outro, emerge necessariamente a questão da relação entre a doutrina tal como aparece na codificação e na vasta literatura espírita nacional, e a doutrina tal como vivida pelos grupos estudados. Essa relação é extremamente complexa. ${ }^{10} \mathrm{~A}$ análise dessa literatura, bem como da codificação, forneceria em si material para um trabalho específico. Dados os limites da pesquisa, optei por assumir a perspectiva e leitura dos grupos pesquisados. Além das obras da codificação, os demais autores que li me foram por eles indicados. Assim sendo, a análise da doutrina, desde os autores sugeridos até a sua interpretação, está filtrada pela leitura do próprio grupo.

A pesquisa no centro possibilitava-me o acesso ao Espiritismo como um todo, isto é, à experiência do estudo, da caridade e da mediunidade nessa religião. Por esse motivo realizei lá o trabalho mais intenso e prolongado. A pesquisa no ICEB punha-me em contato de maneira mais explícita com a ênfase intelectual característica do Espiritismo. A leitura da literatura espírita revelou-se um auxílio indispensável para a obtenção de dados e compreensão da doutrina.

Entretanto, minha intenção não era realizar um estudo de caso dessas instituições, e sim tomálas como referência para uma análise do Espiritismo como um sistema de crenças e práticas. Assim, para o controle e relativização dessas experiências de pesquisa, fui esporadicamente durante o período do trabalho aos dois outros centros já mencionados.

Realizei também oito entrevistas formais. No Lar de Tereza entrevistei duas de suas diretoras e sua presidente, e dois médiuns e colaboradores com quem freqüentei o Desenvolvimento Mediúnico. No ICEB entrevistei um de seus frequientadores e seu presidente. Uma colaboradora e médium do André Luiz foi também entrevistada. Quatro dessas entrevistas foram feitas na casa dos entrevistados e as demais no centro, em horários apropriados.

Aos poucos certifiquei-me de que essas diferentes instituições eram parte de uma rede espírita maior. Em seu público e colaboradores o ICEB congrega cooperadores de diferentes centros, entre os quais o Lar de Tereza. Por sua vez, o presidente do ICEB é membro do Conselho Consultivo do Lar de Tereza, dá passes e palestras regulares nesse centro e sua esposa o freqüenta assiduamente. Os expositores do ICEB também proferiam periodicamente palestras no André Luiz. Alguns médiuns do André Luiz frequientavam o ICEB. Por sua vez, cada expositor do ICEB é colaborador de um centro específico. Nas entrevistas que realizei com colaboradores do Lar de Tereza, algumas pessoas atribuíam sua entrada no Espiritismo a um famoso médium de um centro localizado em Bento Ribeiro, outras haviam freqüentado anteriormente os mesmos centros.

\footnotetext{
${ }^{10}$ Para um trabalho que problematiza essa relação no caso do Budismo, ver Spiro, 1971.
} 
Há certamente diferenças de ordens diversas entre essas instituições.O Lar de Tereza é um centro pequeno, situado na zona sul. Seu público constituía-se, em sua maior parte, de pessoas de camadas médias, brancas e moradoras da zona sul do Rio de Janeiro. Seus organizadores eram sobretudo mulheres de meia-idade. O Grupo Espírita André Luiz é um centro grande, num prédio de quatro andares, cuja sala de estudos comporta cerca de 500 pessoas sentadas. Localizado na Tijuca, seus frequientadores, também de camadas médias, tendem a ser moradores da zona norte do Rio de Janeiro. A presença de negros era maior do que no Lar de Tereza. O público do ICEB combinava em sua composição o dessas duas instituições. Apesar do caráter distintivo do ICEB, e de algumas diferenças de ênfase e organização no funcionamento do Lar de Tereza e do André Luiz, ressalto para os fins desta pesquisa o fato de essas três instituições definirem-se como exclusivamente espíritas.

O Templo Espírita Tupyara, por sua vez, é um centro misto, que combina sessões umbandistas e espíritas. Seu galpão central comporta cerca de 3 mil pessoas. Seu público reunia tanto pessoas de camadas médias como das camadas mais pobres, brancas e negras. Todas as pessoas das três instituições acima mencionadas que entrevistei conheciam-no, já haviam recorrido a seus serviços alguma vez ou sabiam de quem o fizera. Uma médium do André Luiz dava palestras regulares lá. Todos, apesar de se distinguirem dele, no sentido em que colaboravam em centros exclusivamente espíritas, respeitavam-no em virtude do trabalho de operações fluídicas que lá se faz. ${ }^{11}$ A presença do Tupyara nessa rede tornava palpável a questão da relação entre Espiritismo e Umbanda. .

A análise do Espiritismo que empreenderei tem como foco o Lar de Tereza. O grupo de referência central compõe-se de suas organizadoras e de parte de seus freqüentadores com os quais tive maior contato. O material relativo ao ICEB será utilizado complementarmente. Na medida em que essa instituição potencializa em sua prática apenas um dos aspectos do Espiritismo, presente também no centro estudado, esse procedimento pareceu-me o mais adequado. A literatura espírita fornece um componente relevante para a compreensão desse sistema de representações. A ela recorro nos momentos oportunos. O ICEB por um lado, e o André Luiz e o Tupyara por outro, permitindo uma visão de parte do Espiritismo no Rio de Janeiro, fornecem alguns parâmetros para a compreensão do lugar do Lar de Tereza nesse contexto e para a discussão das fronteiras tanto externas como internas do Espiritismo.

\footnotetext{
${ }^{11}$ Para operações fluídicas, ver o capítulo IV.
} 


\section{O Racional e o Místico}

$\mathrm{Na}$ autodefinição dos grupos com que trabalhei, a codificação de Allan Kardec ocupa um lugar central. Sua importância pode ser percebida em vários planos:

1. É o que unifica em sua visão o Movimento Espírita, permitindo sua distinção de "outras formas de Espiritualismo". A frase "o Espiritismo é uma doutrina codificada por Allan Kardec" é dita em qualquer conversa preliminar com os espíritas.

2. Constitui-se na fonte última de autoridade em discussões doutrinárias.

3. Nas diversas sessões e atividades espíritas, a sua leitura, estudo e comentário ocupam um lugar relevante.

A codificação é percebida como tendo inaugurado no mundo uma nova era: a espírita, precedida pela era cristã "codificada" no Novo Testamento, e pela era judaica "codificada" no Velho Testamento. Essas sucessivas revelações são vistas como correspondendo a fases evolutivas do homem. Desse modo, embora o Espiritismo tenha sido revelado

no momento exato em que o mundo se preparava para entrar numa fase superior de desenvolvimento (Livro dos Espíritos, Introdução),

muitas verdades permanecem ainda ocultas, pois os homens não alcançaram ainda toda a sua maturidade espiritual.

A codificação é um conjunto de cinco obras: o Livro dos Espíritos, que aparece pela primeira vez em 1857, e contém "o núcleo e arcabouço geral da doutrina"; o Livro dos Médiuns, continuação do primeiro e que "pesquisa o processo das relações mediúnicas, estabelecendo as leis e condições do intercâmbio espiritual"; o Evangelho segundo o Espiritismo, que explicita o conteúdo moral da doutrina; $O$ Céu e o Inferno, que discute "as penas e gozos terrenos e futuros"; A Gênese, os Milagres e as Predições, que "trata dos problemas genésicos e da evolução física da terra". ${ }^{12}$

Allan Kardec é apenas o codificador dessas obras elaboradas a partir de um diálogo com os Espíritos da Verdade ou superiores. ${ }^{13}$ Essa forma de elaboração da doutrina é extremamente importante e indissociável de seu conteúdo. O Espiritismo é legítimo aos olhos de seus adeptos, por ter sido transmitido pelos Espíritos, não sendo assim uma criação humana. Ao mesmo tempo é a própria doutrina que fundamenta a existência dos Espíritos e suas formas de comunicação com este mundo. A mediunidade, a possibilidade de comunicação entre homens e espíritos, aparece desde já como um ponto central desse sistema.

\footnotetext{
${ }^{12}$ Abrevio nas citações Livro dos Espíritos por LE, Livro dos Médiuns por LM e Evangelho segundo o Espiritismo por ESE.

${ }^{13} \mathrm{O}$ Livro dos Espíritos é todo em forma de perguntas, feitas por Kardec, e respostas dadas pelos Espíritos em sessões mediúnicas. Os demais são escritos por Kardec e contêm transcrições de trechos dessas comunicações.
} 
Elaborada num momento histórico em que o pensamento filosófico e científico estava dominado pelo racionalismo e pelo evolucionismo, os ideais da razão e do conhecimento racional, opostos às noções de sobrenatural e mágico, são bastante explícitos nas obras da codificação. As noções de revelação e experiência geralmente pensadas como opostas encontram-se combinadas no Espiritismo. A verdade é uma verdade revelada no sentido em que transmitida pelos Espíritos. Contudo, o procedimento através do qual essa revelação ocorreu é visto por Kardec como eminentemente científico, racional, experimental. Através do método dedutivo, Allan Kardec, partindo de um efeito (o fenômeno das mesas girantes), chega à sua causa (a ação inteligente dos Espíritos):

(...) Apliquei a essa nova ciência, como até então o tinha feito, o método de experimentação: nunca formulei teorias preconcebidas; observava atentamente, comparava, deduzia as consequiências, dos efeitos procurava remontar às causas pela dedução e pelo encadeamento lógico dos fatos, não admitindo como válida uma explicação senão quando ela podia resolver todas as dificuldades da questão. (...) Agi com os Espíritos como o teria feito com os homens: eles foram para mim, desde o menor até o mais elevado, meios de colher informações e não reveladores predestinados (9: em $O Q u e$ é o Espiritismo, citado por Lossio, 1979: 75).

Os Espíritos assim são percebidos

não como abstrações, mas como seres definidos, limitados, circunscritos (LM: 65).

A comunicação espiritual, erguendo-se à evidência dos sentidos, ganha o estatuto de prova científica. O Espiritismo, na codificação, se apresenta não apenas como uma religião, mas também como uma ciência e uma filosofia pelas implicações a um só tempo filosóficas, científicas e morais que dele decorrem.

Esses dois fatores acima indicados - o tríplice aspecto do Espiritismo e sua ênfase racional estão na raiz de uma avaliação comum a seu respeito na literatura sociológica: a de que no Brasil o Espiritismo teria adquirido um caráter essencialmente "místico", "religioso".

Renshaw (1969: 64-66) assinala a ênfase na noção de cura espiritual e na ação fluídica de forças espirituais como fatores determinantes do rumo que o Espiritismo tomou no Brasil, enfatizando a "caridade mística e a cura mágica e espiritual". Afirmando que,

para a maioria dos espíritas, a fé baseia-se não na razão mas na interpretação de curas como milagres (Renshaw, op. cit. : 152-153). ${ }^{14}$

Com base nesse e em outros autores (Kloppenhurg, 1961b: 63; Warren, 1968b: 397), Diana Brown acredita também que no Brasil o Kardecismo se transformou numa religião mística

\footnotetext{
${ }^{14}$ É interessante ressaltar que em outros momentos, contudo, esse mesmo autor argumenta que o Espiritismo exige uma racionalização da crença, um interesse no estudo: "Ser espírita é uma forma de ser intelectual", 1969: 166.
} 
com crescente ênfase na cura, no misticismo sentimental, nos trabalhos de caridade (Brown, 1974: 33$34)$.

Essa visão implica, de um lado, uma determinada construção da história do Espiritismo no Brasil: a história de como foi adquirido o seu caráter místico. De outro, uma determinada percepção dos grupos que compõem o Espiritismo.

A transformação do Espiritismo numa "religião mística" é vista como tendo começado no final do século XIX, logo após sua chegada no Brasil, com o livro de Jean-Baptiste Roustaing, Revelação da Revelação, que reinterpretaria o Kardecismo, dando-lhe, segundo esses autores, uma conotação expressamente religiosa. Com Bezerra de Menezes, deputado federal pelo Rio de Janeiro e presidente da FEB de 1895 a 1900, esse livro se teria tomado a doutrina oficial do Movimento Espírita Brasileiro. ${ }^{15}$ IS Com base nessa leitura da história dessa religião no Brasil, caracterizam-se no Espiritismo uma maioria mística e uma minoria intelectual. Diana Brown, por exemplo, vê essa maioria mística e religiosa, representada pela orientação da FEB. A ela opõe-se

uma minoria de kardecistas mais intelectualmente orientados que prosseguem na tradição ortodoxa, vêem no kardecismo apenas secundariamente uma religião, e exploram a relação entre a filosofia espírita e temas sociais (Brown, op. cit.: 46).

Essas formulações derivam a meu ver de uma falsa questão. Sem dúvida, o Espiritismo brasileiro, como o próprio Espiritismo Francês codificado por Allan Kardec, ${ }^{16}$ tem um caráter particular, histórico. Todavia, a percepção da particularidade do Espiritismo brasileiro através da noção de seu caráter místico gera alguns problemas.

Como desde o Iluminismo, na tradição do pensamento ocidental, nosso senso comum habituou-se a alinhar a religião do lado oposto ao da Razão, ${ }^{17}$ esses autores confundem-se diante da questão de como chamar de religião uma doutrina que se afirma como racional, como ciência e filosofia. Sem enfrentá-la diretamente, resta-lhes em mãos os adjetivos "místico" e "racional" que qualificam respectivamente o caráter do Espiritismo brasileiro, e o caráter original do Espiritismo tal como concebido na codificação de Allan Kardec. Essa oposição se desdobra naquela percebida no seio do Espiritismo brasileiro entre uma maioria mística, que recobre seus aspectos "religiosos", e uma minoria "intelectualizada", que recobre seus aspectos "filosóficos e científicos".

\footnotetext{
${ }^{15}$ Ver Renshaw, 1975b: 12 e Brown, 1974: 40.

${ }^{16}$ Ver para uma história do Espiritismo em diversos países no século passado o livro de Conan Doyle, A História do Espiritismo. S. Paulo, Pensamento.

${ }^{17}$ Ver a esse respeito Dias Duarte, Luiz Fernando, O Culto do Eu no Templo da Razão. PPGAS, dat.
} 
O racional e a razão como o Espiritismo os entende são de fato noções tomadas da ciência da segunda metade do século XIX. ${ }^{18}$ No Espiritismo a comunicação espiritual é evidência sensível indiscutível, prova irrefutável da existência dos Espíritos. A existência dos Espíritos e sua necessária relação com o mundo dos homens são, em sua visão, parte de leis que regem o universo. Visto como ápice de uma evolução do espírito humano, o racional é aqui também pensado como fruto da observação, como conhecimento das leis que regem os fenômenos, como o empiricamente comprovável. Essa proximidade oculta, porém, o fato de que, como no discurso científico, as noções de razão e de racional são no Espiritismo parte de um sistema maior. A crença simultânea na razão e nos Espíritos, inconciliável do ponto de vista do discurso científico, é para os espíritas plenamente conciliável.

Entendendo a religião como um sistema de representações e práticas, vejo as noções de razão, filosófico, científico e religioso como elementos do sistema de crenças espírita. Como tais, seu sentido só pode ser apreendido no conjunto desse sistema. Os aspectos "religiosos, filosóficos e científicos" só podem em determinados contextos opor-se porque são todos sacralizados. ${ }^{19}$ Chamo atenção, entretanto, para o fato de que esse tríplice aspecto da doutrina se constitui numa base para acusações, construção de fronteiras e distinção de grupos no Espiritismo. Essas fronteiras, porém, não são estanques. Repousam antes na ênfase conferida privilegiadamente a um desses aspectos do que em sua valorização exclusiva.

\section{O Movimento Espírita}

Os espíritas designam o conjunto das atuações que o Espiritismo comporta com o termo Movimento Espírita. O Movimento Espírita abrange desde os lares e centros até institutos culturais, laboratórios de pesquisa, associações profissionais, federações nacional e regionais, hospitais, asilos, orfanatos, imprensa e editoras. Essas atuações podem a princípio privilegiar um dos aspectos acima mencionados ou combiná-los de variadas maneiras.

Ao longo da pesquisa pude identificar algumas linhas de controvérsia atravessando esse movimento. Pelos próprios limites do trabalho e pela dificuldade do acesso a esse tipo de dado, que remete diretamente às tensões e disputas de poder no seio dessa religião, obtive pouca informação sobre a questão. Procuro reunir, a partir de comentários informais e alusões, os dados de que disponho. Mais do que identificar as acusações, grupos que as fazem ou de que lhes são objeto, meu propósito é ressaltar a complexidade do Espiritismo e indicar sobre o que essas acusações falam.

\footnotetext{
${ }^{18}$ Ver por exemplo Comte, 1973.

${ }^{19}$ Utilizo a noção de sagrado no sentido em que Durkheim a emprega, de coisas interditas, separadas, objetos de respeito e que têm formas de acesso específicas. Durkheim, 1968: 43-44.
} 
Nos grupos com que trabalhei, pude perceber em alguns contextos uma oposição entre o caráter "evangélico", de pregação e prática da caridade, do Espiritismo, e o seu caráter "intelectual". Algumas pessoas individualmente podem definir-se como "mais da parte evangélica" ou "mais da parte filosófica". Segundo a avaliação do presidente do ICEB,

reunindo dez espíritas, encontram-se dois que preferem a parte filosófica e oito que dizem: "Ah! eu prefiro o Evangelho!"

Pude perceber também a existência de acusações mais ou menos sutis entre esses dois pólos. Na saída de uma sessão de estudos doutrinários no André Luiz por exemplo, uma senhora espírita comentava comigo:

não entendo nada do que fulano fala, que nem o sicrano que às vezes fala para um grupo muito pequeno de pessoas, a gente às vezes está cansada, procurando uma consolação e vem ouvir falar de espermatozóides,

ou ainda

falou, falou e não falou em Jesus Cristo.

O Instituto de Cultura Espírita do Brasil, preocupa-se em defender-se das qualificações de "elitista". ${ }^{20}$ Certa vez, um de seus expositores comentava que já ouvira algumas críticas:

\section{Ah! Você é lá da Sorbonne!}

E respondia:

Depende, se se quer dizer que lá se estuda, aí sim, é uma espécie de Sorbonne.

Por sua vez algumas instituições podem ser qualificadas como "demasiado evangélicas".

Essas qualificações, pelo que pude perceber, estão associadas em sua base, entre outras coisas, à predileção, aceitação ou não-aceitação de determinados autores espíritas. As instituições e pessoas "mais da parte evangélica" aceitam, por exemplo, a obra de Roustaing, os outros não.

Essas tensões, que expressam possibilidades diversas de leitura e vivência do Espiritismo, permitem entrever a questão crucial da definição dos critérios de verdade nessa religião.

O Espiritismo é uma religião codificada, e a codificação é certamente a fonte última de autoridade no que se refere a questões doutrinárias. Ao mesmo tempo as Federações correspondem nessa religião a um esforço no sentido da unificação doutrinária. Porém, se é possível identificar nessas instituições uma tendência no sentido da uniformização e monopolização dos critérios de

\footnotetext{
${ }^{20}$ Ver, por exemplo, "O Elitismo no meio Espírita" de Deolindo Amorim, in O Mundo Espírita, 29 de fevereiro de 1980.
} 
verdade, algumas características estruturais desse sistema de crenças impedem a sua realização plena.

De um lado, devido à importância da noção de livre-arbítrio nesse sistema (ver o capítulo II), os centros não estão obrigados a filiar-se à Federação. ${ }^{21}$ É o caso do Lar de Tereza, que, contrariamente ao André Luiz, "optou" por não federar-se, pois, como me explicou sua presidente,

a Federação apenas orienta, diz como deveria ser, mas não pode interferir, porque há na doutrina uma coisa fundamental, que é o livre-arbítrio.

A própria noção de Movimento Espírita enfatiza a "não-existência de uma instância superior com poderes para ditar normas". A divergência de orientação entre os centros era explicitamente reconhecida no Lar de Tereza. Como cada centro tem um mentor, amigos e benfeitores espirituais, essa diferença de orientação era explicada pelos espíritas pela "individualidade" desses Espíritos. Pelo mesmo motivo era também constante a recomendação aos médiuns da casa acerca da necessidade de aceitar-se o modelo ali imprimido.

É importante escolher uma casa com a qual nos afinamos, porque na hora do trabalho é importante que confiemos na orientação da casa, se não vira bagunça. Vamos observar e, na hora de aceitar, aceitar mesmo e começar a trabalhar conscientes, com dúvida é melhor não aceitar. A pessoa em posição de crítica vai perturbar ou vai ser isolada pelos amigos espirituais.

No limite recoloca-se nesse ponto a questão das fronteiras externas do Espiritismo, pois, como comentaram alguns informantes:

tem muito centro com vela acesa, imagens...

ou ainda,

há centros que fazem camuflagem, às vezes se filiam e depois descobre-se que estão fazendo certas coisas. Não que eu condene, mas que diga abertamente.

De outro lado, como chamei atenção acima, tão importante quanto a mensagem codificada é a relação através da qual ela o foi - a comunicação entre Allan Kardec e os Espíritos da Verdade. A isso acrescentam-se dois outros fatores. A codificação é apresentada por Kardec, e vista pelos espíritas como uma obra fundamental mas incompleta. Muitas verdades permaneceram ainda ocultas aos homens. Ao mesmo tempo, segundo o Espiritismo, todo homem é natural e potencialmente um médium. Não havendo portanto, como em outros sistemas, uma hierarquia ritual

\footnotetext{
${ }^{21}$ Segundo informação de um dos diretores da FEERJ, há no Estado do Rio de Janeiro, para um total de 420 casas espíritas, 189 filiadas a essa instituição, situadas em sua maioria na capital. Para filiar-se, segundo esse mesmo diretor, um centro precisa comprovar que lá se pratica a doutrina "tal como codificada por Allan Kardec". Não pude todavia ter acesso à relação das instituições afiliadas. Em virtude de vários pedidos com finalidades políticas eleitoreiras, a diretoria da FEERJ, conforme me foi informado, proibiu o acesso a essa relação.
} 
evidente, não há a princípio intérprete humano mais qualificado do que outro. Se a verdade, como o Espiritismo a concebe, é uma propriedade dos Espíritos, como assegurar sua transmissão para o plano humano? Se todos são médiuns, que critérios tornam apenas alguns médiuns legítimos transmissores da verdade? A possibilidade de rejeição de determinadas obras e aceitação de outras tem um espaço. Esse ponto é decisivo e será retomado ao longo dos capítulos III e IV.

Assim, se os aspectos "religiosos, científicos e filosóficos" do Espiritismo podem ser vistos como complementares, eles estão também como que sujeitos à ação de uma força centrífuga. Emerge daí todo o problema das diferenças de ênfases e tensões internas ao movimento, as acusações de "demasiado evangélico" no caso de uma ênfase na caridade, de "elitista" no caso de uma ênfase no estudo, e os perigos, extremamente ameaçadores da mediunidade como um valor em si mesmo.

Por ora, pretendi apenas chamar a atenção para a diversidade de ênfases e complexidade do Espiritismo no Rio de Janeiro. Os grupos com que trabalhei são expressivos de uma determinada tendência no interior dessa religião. É sobre esses grupos e sobre sua visão do Espiritismo que este livro falará. 
capítulo II

\section{A COSMOLOGIA ESPÍRITA}

\section{A Religião como Sistema de Representações e Práticas}

Se diferentes teorias e áreas de conhecimento concordam em debruçar-se sobre um objeto comum - a religião -, as maneiras de vê-lo e defini-lo diferem em muito. A religião pode ser falsa consciência (Marx), castelo de erros (Tylor), sociedade hipostasiada (Durkheim). Em sua definição estão embutidas teses sobre a natureza do social. O campo é polêmico, e, como sempre, a noção de religião constrói-se, de um lado, por aqueles que a vivem e, de outro, pelas teorias que a pensam e questões que estas enfatizam.

Contudo, por mais diferentes que sejam, há uma questão de fundo, de natureza epistemológica e existencial, que perpassa todas essas teorias: qual o sentido ou significado das religiões em geral e de cada religião? Qual a relação entre o sentido que se percebe nessa forma de pensamento e ação partilhadas e o seu sentido para os atores tomados como grupo?

A distinção entre a realidade da crença e a realidade de seu objeto (Tylor, 1970; Durkheim, 1968; Robertson Smith, 1972) é um dos primeiros passos que possibilita o estabelecimento da religião como um campo de reflexão antropológico. Sob esse ponto de vista, a crença enquanto fenômeno social é portadora de uma verdade que não é contudo aquela que seus adeptos lhe atribuem. Porém como e onde localizar essa verdade?Existe um objeto de crença exterior à própria crença? Qual o estatuto lógico/filosófico do discurso religioso?

A perspectiva aqui adotada vê a religião como um sistema de representações e práticas da ordem do simbólico. Essa definição abriga dois dos postulados da Escola Sociológica Francesa:

1. a visão do simbolismo como um fenômeno da ordem do pensamento, entendendo o pensamento como constitutivo da experiência (Mauss, 1978);

2. a visão do social como uma categoria que se constitui da particularidade dos aspectos sob os quais a apreendemos (jurídico, político, econômico, religioso etc.) (Mauss, 1978; LéviStrauss, 1976).

Nela estão embutidas duas questões teóricas correlatas:

Em primeiro lugar, embora tendo em comum a afirmação do simbolismo como constitutivo do social, as abordagens simbólicas variam enormemente entre si. ${ }^{1}$ Em segundo lugar,

\footnotetext{
${ }^{1}$ Para a leitura crítica dessas abordagens ver Sperber, 1974 e Skorupski, 1976.
} 
o entendimento da religião como um sistema de representações (crenças) e práticas (ritos) divide o conjunto do qual se parte (a totalidade do sistema religioso) em dois planos aos quais a análise recorrerá: o plano do pensamento, do intelecto - as representações; e o plano do comportamento, das ações humanas - os rituais. ${ }^{2}$

Ao chamar atenção para a diversidade das abordagens simbólicas, não é minha intenção discuti-las de maneira exaustiva nos limites deste livro. A segunda questão acima indicada fornecerá um ponto de partida para a elucidação de alguns problemas levantados por algumas dessas abordagens e permitirá o delineamento mais preciso da perspectiva teórica aqui adotada.

$\mathrm{Na}$ Antropologia Social a noção de ritual permaneceu por um bom tempo reservada ao domínio do religioso e do mágico, referindo-se ao comportamento místico, tendo por base em última análise o critério da irracionalidade (ver, por exemplo, Evans-Pritchard, 1972; Gluckman, 1962; Turner, 1967). O ritual nesse contexto designa um comportamento oposto ao não-místico ou racional.

A noção de uma linguagem e de um comportamento não mais "místicos" mas "simbólicos", ao enfatizar a necessidade da apreensão da lógica própria e interna aos sistemas estudados,desloca a questão da racionalidade e lança as bases para uma visão não substancialista da noção de ritual.

Radcliffe-Brown, em seu trabalho "Tabu" (Radcliffe-Brown, 1973:179), define o ato ritual como diferindo do técnico por ter sempre algum elemento expressivo ou simbólico:

em qualquer atividade técnica, a adequada declaração do propósito de certo ato ou série de atos constitui por si mesmo uma explicação suficiente.

No ritual, contudo, interessa

são a consideração de seu propósito ou razão, mas a de seu significado.

Leach (Leach, 1972a) elaborará posteriormente essa distinção, dividindo as ações humana sem duas grandes categorias: as ações que "fazem coisas", ou seja, "alteram o estado físico do mundo", e as ações que "dizem coisas, i. e., fazem afirmações (geralmente relativas às relações humanas e status social)". Esses dois tipos de ação não são categorias excludentes nem intrinsecamente diferentes:

uase toda ação humana ocorrendo num contexto culturalmente definido pode ser assim classificada: tem um aspecto técnico, que faz alguma coisa, e um aspecto estético, comunicativo, que diz alguma coisa.

\footnotetext{
${ }^{2}$ A questão aparentemente tola da primazia lógica e teórica do rito sobre o mito, que na história da Antropologia alinha, de um lado, Robertson Smith e Durkheim e, de outro, Tylor e Frazer, se enraíza aí.
} 
Nos rituais - técnicas de informação nas quais a palavra e o comportamento são indissociáveis e cuja estrutura abriga conhecimentos complexos sobre a natureza e a sociedade (Leach, 1971) - o segundo aspecto é particularmente proeminente. ${ }^{3}$

Essa ênfase na dimensão expressiva e comunicativa do comportamento social torna o conceito de ritual aplicável a todos os domínios da vida social. ${ }^{4}$ Se considerarmos ao mesmo tempo que o comportamento humano pode ser percebido como intrinsecamente expressivo e simbólico (Geertz, 1978), toda ação e palavras humanas são, nesse sentido amplo, rituais. O conceito de ritual ampliase tanto que a distinção entre o mito e o rito revela-se analiticamente inoperante. Leach, por exemplo, explicita claramente essa visão em sua reivindicação de uma não-distinção entre os ritos (dramatização do mito) e os mitos (recapitulação do drama) (Leach, 1971:246):

o mito, segundo minha terminologia, é a contrapartida do ritual. O mito implica o ritual, e o ritual implica o mito, são uma única e mesma coisa (...).

O mito, considerado como enunciado verbal, "'conta" a mesma coisa que o ritual considerado como enunciado em ato:

se eu desenho grosseiramente no quadro-negro o diagrama de um automóvel e escrevo embaixo: "Isto é um automóvel", os dois enunciados - o desenho e a escritura - dizem a mesma coisa (Leach, 1972b: 36).

E aquilo que o ritual "diz", "expressa" ou "dramatiza" são temas, valores, elementos ou relações sociais. É assim, na dinâmica dessa relação entre algo que está dito nele e algo que existe fora dele mas do qual ele também participa, e de maneira decisiva, que o ritual deve ser entendido.

Lévi-Strauss (1971: 598-603) procura precisar a noção de ritual, distinguindo entre duas formas de existência das representações. A primeira consiste em relatos explícitos, com evidente organização interna. A segunda é implícita: nela, as representações existem de maneira fragmentada, permanecendo ligadas a uma ou outra fase do ritual. Essa distinção importa no sentido em que, para esse autor, a apreensão do caráter próprio do ritual requer o isolamento das crenças e representações que fazem parte do ritual mas que com ele não se confundem. O rito, em sua visão, consiste em

palavras proferidas, gestos realizados, objetos manipulados, independentemente de toda glosa ou exegese exigida por esses três tipos de atividade e que remetem não ao ritual mas à mitologia implícita.

\footnotetext{
${ }^{3} \mathrm{O}$ mesmo ponto de vista é formulado por esse autor de maneira um pouco distinta in Leach, 1972b: 35.

${ }^{4}$ Ver também a esse respeito Da Matta, 1979: 30.
} 
Gestos e objetos substituem as palavras, conotando cada um, de maneira global, um sistema de idéias e representações:

ao utilizá-los, o ritual condensa sob forma concreta e unitária procedimentos que, sem ele, seriam discursivos. Ele não realiza, portanto, gestos, não manipula objetos como na vida corrente, para obter resultados práticos oriundos de operações em cadeia, cada uma ligada à precedente por um laço de causalidade (...).

Quanto às palavras, deve-se perguntar não pelo que é dito, o que remete ao sistema de representações, mas pela maneira como o dizem. O ritual caracteriza-se ainda por um apelo constante a dois procedimentos: a fragmentação - no interior das classes de objetos e tipos de gestos o ritual distingue infinitamente; e a repetição - uma mesma fórmula ou gestos são repetidos várias vezes. Do recurso sistemático a esses dois procedimentos, Lévi-Strauss deriva a razão profunda do ritual. O mito e o rito procedem em sua visão de movimentos de pensamento que se exercem em direções contrárias:

A fluidez do vivido tende constantemente a escapar pelas malhas da rede que o pensamento mítico lançou sobre ele para reter dele apenas os aspectos mais contrastados. Ao fragmentar as operações que detalha ao infinito, e que repete sem cansar, o ritual se dedica a um minucioso remendar, ele preenche os interstícios, e alimenta assim a ilusão de que é possível remontar no sentido oposto ao do mito, refazer o contínuo a partir do descontínuo. Nesse sentido o rito não reforça, mas inverte o procedimento do pensamento mítico que, por sua vez, cinde o mesmo contínuo em grandes unidades distintas entre as quais institui separações.

Adoto essa visão como um ponto de partida. Se essa concepção do ritual é polêmica por divergir das demais concepções existentes, cabe assinalar que ela mantém com estas alguns pontos de contato relevantes. O caráter condensador dos procedimentos rituais é enfatizado também, entre outros autores, por Turner (Turner, 1973) e por Leach (Leach, 1971). O ritual, pensado aí por oposição aos "atos da vida corrente", que "visam resultados práticos", tem a mesma base que em Radcliffe-Brown e Leach (op. cit.).

Neste livro trabalharei com esses dois planos de análise: as representações implícitas ou explícitas, e os rituais. Minha tentativa será a de através deles apreender as regras, princípios e categorias que caracterizam o Espiritismo como um sistema de pensamento. Circunscrevo, assim, os limites da análise que me proponho a realizar, por opção teórica, ao domínio religioso. Evidentemente, os agentes sociais concretos em questão existem no mundo e o ser espírita é apenas um dos aspectos da construção de suas identidades; o domínio religioso é apenas um dos domínios no qual se movem cotidianamente. Trata-se, todavia, de um domínio produtor de determinados tipos 
de ethos e visões de mundo (Geertz, 1978), um domínio no qual se forjam matrizes de leitura e de experiência do social (Weber, 1967a, 1967b).

Minha questão é, em última análise, a do sentido. Tentarei circunscrevê-la na compreensão das regras e categorias que governam esse sistema de pensamento, e de sua relação com valores e temas culturais mais abrangentes.

No restante deste capítulo, examino as representações espíritas explícitas. Baseio-me para tanto na codificação e em algumas outras obras espíritas, bem como na reflexão manifesta que os espíritas fazem sobre a doutrina nos diferentes rituais que realizam. No capítulo seguinte discuto o centro espírita, e inicio a discussão de seu sistema ritual a partir de três categorias do discurso espírita, o estudo, a caridade, a mediunidade, examinando as representações que se encontram embutidas nesse plano de sua prática. O capítulo IV detém-se na análise da categoria mediunidade.

\section{A Cosmologia Espírita}

\subsection{O Mundo Visível e o Mundo Invisível}

O princípio de tudo é no Espiritismo Deus, concebido segundo a tradição judaico-cristã: Deus é o criador do universo a partir do nada. Uma vez criado, o universo constitui-se de dois elementos básicos: espírito e matéria. Essa dualidade é um dos pilares desse sistema, a relação entre esses termos, permanentemente desdobrada, funda o movimento e o devir do mundo como os espíritas o pensam.

À oposição entre um princípio material e um princípio espiritual corresponde aquela entre seres materiais e seres imateriais, e, de maneira mais abrangente, a oposição entre o Mundo Visível e o Mundo Invisível, ou, como os espíritas também o chamam, o Plano Terreno e o Plano Espiritual. O Mundo Invisível é "eterno e preexistente a tudo" e o Mundo Visível é "secundário, poderia deixar de existir ou nunca ter existido sem alterar a essência do mundo espírita". Idealmente, há de um lado o Mundo Invisível, identificado ao espiritual, e de outro o Mundo Invisível, associado ao material. Essa dualidade é traduzível na clássica oposição da sociologia religiosa: o Mundo Invisível corresponde ao espiritual, sagrado, puro, e o Mundo Visível, ao material, profano, impuro (Durkheim, 1968; e Douglas, 1966). Contudo, puro e impuro, sagrado e profano não são dois contrários que se excluem, mas antes dois aspectos sempre presentes de toda realidade religiosa (Hubert e Mauss, 1968). Assim, se idealmente o Mundo Espírita ou Invisível dispensa a existência do Mundo Visível, no funcionamento desse sistema os dois termos complementam-se numa relação de oposição hierárquica. ${ }^{5}$ Em um plano, o Mundo Visível opõe-se

\footnotetext{
${ }^{5}$ Para a discussão dessa noção, ver Dumont, 1966.
} 
ao Mundo Invisível. Em outro, os dois mundos complementam-se, o Mundo Invisível transcende, engloba e confere sentido ao Mundo Visível. A realidade religiosa espírita nasce dessa permanente relação.

Essa relação de complementaridade entre os dois mundos se ordena segundo dois eixos, um diacrônico e outro sincrônico. O eixo diacrônico corresponde às passagens de cada Espírito de um mundo a outro, à noção de reencarnação. Os Espíritos, principais componentes do Mundo Invisível, ${ }^{6}$ têm vida eterna. Em sua trajetória cósmica passam por várias encarnações até atingirem o grau de Espíritos superiores. A vida de um Espírito é, por conseguinte, um encadeamento de passagens entre os dois mundos, de encarnações, desencarnações e reencarnações.

O eixo sincrônico remete à relação entre Espíritos encarnados (Mundo Visível), de um lado, e Espíritos desencarnados (Mundo Invisível), de outro, à noção da comunicação espiritual. Ao encarnarem, os Espíritos revestem-se temporariamente de um corpo. Cada homem, Espírito encarnado, tem portanto uma natureza dupla, é corpo e alma. O corpo com seus órgãos torna-se o instrumento material da ação do Espírito. Por esse motivo, todo ser humano é sempre um medianeiro - está necessariamente em relação com Espíritos desencarnados -, e potencialmente um médium - é capaz de comunicar-se explicitamente com Espíritos desencarnados. Este eixo será examinado no capítulo III e, mais especificamente, no IV.

No eixo da diacronia, a relação entre os dois mundos é governada pelas leis que regem o universo: a lei do progresso e da evolução, a lei da reencarnação, a lei do carma ou da causalidade cósmica.

\subsection{A Evolução, o Progresso e o Desenvolvimento da Desigualdade entre os Espíritos}

O Espiritismo, como todas as religiões, se vê diante da necessidade de dar conta do problema da imperfeição do mundo (Weber, 1974: 412-17). Como conciliar a idéia da criação de um mundo imperfeito por um Deus perfeito e onipotente? A resposta espírita, em nome da razão e do bom senso, afirma que, se Deus, que é perfeito, criou um mundo imperfeito, onde há o Bem e o Mal, é porque essa criação obedece a suas razões e intenções essencialmente justas e cognoscíveis.

Os principais componentes do Mundo Invisível são os Espíritos, centelhas divinas, partes de Deus. São entendidos não

como abstrações, mas como seres decididos, limitados, circunscritos (LM: 65).

\footnotetext{
${ }^{6}$ Os espíritas escrevem Espírito com maiúscula, distinguindo-o de espírito com minúscula. No primeiro caso, trata-se de uma individualidade moral, de uma subjetividade. No segundo caso, trata-se do elemento que se opõe à matéria. Sigo neste livro essa grafia.
} 
Têm como atributos peculiares o pensamento, a inteligência e vontade que o dotam de livrearbítrio, constituindo-os como individualidades morais. Correspondem a um empobrecimento de Deus, devendo um dia reintegrar-se a sua origem: sua vida, ao contrário de Deus, teve um começo, mas como a dele não terá fim. Os Espíritos foram criados por Deus, simples e ignorantes, e a cada um foi atribuída uma missão para conduzi-lo à perfeição. Cada Espírito percorrerá uma trajetória que evolui da simplicidade e ignorância à perfeição. Há um ponto inicial, um "ponto zero" no qual há uma igualdade inicial na imperfeição e no caminho que deverão percorrer; e um ponto final, "infinito + relativo" ("porque infinito absoluto só Deus"), que todos um dia, não importa quando, alcançarão, e que representa a possibilidade de uma igualdade na perfeição. Há assim uma dupla igualdade entre os Espíritos:

1. substancial, no sentido em que são seres da mesma natureza, individualidades morais que têm como principais atributos a inteligência, a vontade e o livre-arbitrio;

2. posicional, pois todos foram criados simples e ignorantes, num ponto zero de sua trajetória, tendo à frente um mesmo alvo a alcançar. Todavia, essa igualdade primeira na imperfeição é sobretudo uma base a partir da qual se desenvolve uma desigualdade: embora todos os Espíritos tenham uma mesma natureza e um mesmo alvo a alcançar, cada percurso será único. Nele e a partir dele se diferenciarão.

O motor da trajetória espiritual é a relação que o Mundo dos Espíritos estabelece com o Mundo Visível ao longo de sucessivas encarnações. A encarnação, o Mundo Visível, idealmente identificados à materialidade e à imperfeição, ocupam um lugar decisivo. São a possibilidade de progresso do Espírito. Neles os Espíritos originariamente iguais diferenciam-se, tornam-se mais ou menos imperfeitos, mais ou menos próximos da perfeição. O Mundo Visível, é o lugar da produção de uma desigualdade justa, pois que fundada no mérito:

Onde estaria o mérito, sem a luta? Se todos os Espíritos tivessem sido criados perfeitos, não teriam o merecimento para gozar dos benefícios dessa perfeição.

Ou ainda:

a desigualdade existente é necessária a sua personalidade, a missão que lhes cabe nos diferentes graus e está nos desígnios de Deus com vistas à harmonia do universo (LE: 102).

Combinam-se nessas proposições dois valores aparentemente contraditórios. 
Ao mesmo tempo que o Espírito possui livre-arbítrio, a ele é atribuída uma missão, um caminho predeterminado até o seu alvo, alvo e percurso pensados como indispensáveis à harmonia do universo. De um lado, a noção de livre-arbítrio aparece como atributo essencial dessa individualidade moral, tornando-a responsável pelos seus atos. De outro, a noção de determinismo emerge de maneira igualmente marcante, pois essa individualidade existe num universo regido por leis invioláveis e imutáveis de origem divina. Essa combinação configura uma tensão que perpassa os vários planos desse sistema religioso. Tensão e não contradição. Pois, de um lado, o livrearbítrio, dispositivo onde se ancora a individualidade moral do Espírito, e sobre o qual repousa sua diferenciação dos demais, é antes de tudo uma condição para a reintegração do Espírito à plenitude, a Deus. De outro lado, o determinismo a que o Espírito e seu livre-arbítrio estão submetidos é a manifestação mesma do divino.

A tensão entre livre-arbítrio e determinismo atravessa grande parte da tradição religiosa e filosófica ocidental (Berofsky, 1973). ${ }^{7}$ Nesse sentido, o Espiritismo, mesmo combinando algumas das noções clássicas das grandes religiões orientais como a de reencarnação e carma, aproxima-se dessa tradição. A postulação em Kardec de uma igualdade originária entre os Espíritos pode ser pensada como análoga àquela dos filósofos que pensaram a democracia como Rousseau e Hobbes. Na visão de Dumont (Dumont, 1978), esse procedimento denota a afirmação da noção de indivíduo como valor, como sujeito, mônada, cuja existência é pensada como anterior ao social. No Espiritismo, porém, essa igualdade primeira existe num universo que é de início hierárquico. Os Espíritos, iguais em sua origem, são partes de um todo, a ele pertencem e a ele retornarão. Sob um aparente dualismo, há no Espiritismo na verdade uma tripartição do universo. Transcendendo o Mundo Visível e o Mundo Invisível que estabelecem distinções e descontinuidades está Deus, a Plenitude, a Perfeição, a Indistinção. Essa tripartição reaparece, como veremos adiante, nas representações espíritas da pessoa.

Se livre-arbítrio e determinismo podem ser associados a valores culturais mais gerais cabe ressaltar que elas ganham nesse sistema um sentido específico. Tal como o Espiritismo os formula, esses valores constituem-se, como veremos, numa polaridade relevante para pensar a relação entre a pessoa (ser humano) e o cosmos.

A individualidade moral que é o Espírito existe num mundo governado por leis divinas imutáveis, entre elas a da existência necessária do Mal. A presença do Mal explica e gera a desigualdade e a imperfeição que não são senão uma das faces de uma moeda que tem no seu reverso a ordem e a justiça que nele vigem.

\footnotetext{
${ }^{7}$ Ver também, acerca da noção de livre-arbítrio no pensamento cristão, Gilson, 1978.
} 
A questão da origem da desigualdade entre os Espíritos, tema de freqüentes reflexões por parte dos espíritas, conduz ao problema do Mal. Numa palestra a que assisti no ICEB, o expositor desenvolveu o seguinte raciocínio:

Como os Espíritos originariamente dotados de livre-arbítrio e iguais se diferenciam? É a grande figura da queda do homem, do pecado original: uns cederam à tentação, outros resistiram. De onde contudo vieram as influências? Dos Espíritos Imperfeitos que procuram envolvê-lo e domá-lo (...). Foi o que se quis representar na figura de Satanás, Porém, se todos têm as mesmas possibilidades, por que uns cedem e outros não? Num primeiro momento, o Espírito recém-criado observa, compara e tira conclusões. Num segundo momento, começa a discernir o que é certo e errado, aprende a distinguir o Bem e o Mal. É a moral que chega na esteira da razão. Com a capacidade de discernir, o Espírito pode, por meio do atributo da vontade, optar pelo Mal: "Está bem, 'tá errado mas eu quero assim." É a razão pela qual as gradações começaram a surgir.

A Perfeição e o Bem têm como contrapartida necessária a Imperfeição e o Mal. É do confronto do Espírito com esses valores opostos que nasce o seu mérito, e a justiça que reina no mundo. O Espírito, dotado de livre-arbítrio, tem culpa no Mal e mérito no Bem. Diferenciando-se, os Espíritos, seres de uma mesma natureza, subdividem-se em ordens de uma escala evolutiva cujo princípio de classificação é a oposição entre o espiritual, identificado ao Bem e ao Puro, e o material, identificado ao Mal e ao Impuro. Os Espíritos situam-se nessa escala numa gradação que vai do mais material $=$ inferior, ao totalmente desmaterializado $=$ superior .

Na escala espírita, os Espíritos estão distribuídos em três ordens (LE: 94). A terceira ordem é a dos Espíritos imperfeitos. Suas características são a predominância da matéria sobre o espírito, a propensão para o mal ("na verdade, eles não têm senso moral, nós é que temos e assim os classificamos"), idéias pouco elevadas, sentimentos mais ou menos abjetos.

Essa ordem subdivide-se em:

1. os impuros, que, quando encarnados, inclinam-se a todos os vícios;

2. os levianos, ignorantes e inconseqüentes;

3. os pseudo-sábios, que julgam saber mais do que sabem;

4. os neutros, apegados às coisas materiais, e que tendem tanto para o Bem como para o Mal;

5. os batedores e perturbadores, que produzem efeitos físicos.

Estes últimos são na verdade uma classe paralela que inclui Espíritos de toda terceira ordem.

A segunda ordem é a dos Espíritos bons. Caracterizados pelo predomínio do espírito sobre a matéria ("sem vaidade nenhuma todos nós podemos estar aqui"). Esses Espíritos conservam, 
quando desencarnados, traços de sua existência corpórea na linguagem e nos hábitos. Essa ordem subdivide-se em:

1. benévolos, dotados de bondade e saber limitados, e cujo progresso se dá mais no sentido moral que intelectual ("por exemplo, aqueles a que em outros arraiais espiritualistas se dá o nome de Preto Velho");

2. os sábios, que progridem mais no sentido intelectual que moral;

3. os prudentes, que podem julgar com precisão os homens e as coisas;

4. os superiores, dotados de ciência, sabedoria e bondade, que encarnam na Terra somente por exceção no desempenho de uma missão de progresso.

A primeira ordem é a dos Espíritos puros, que já não têm influência alguma da matéria. Sua superioridade intelectual e moral é absoluta e não estão mais sujeitos à encarnação.

A escala espírita permite a releitura da trajetória evolutiva do Espírito num sentido unívoco e não ambíguo. No início, encontra-se não mais a simplicidade e ignorância, mas a materialidade e inferioridade. Cada Espírito encarnado ou desencarnado está em determinado ponto de sua trajetória, que, desse modo, parece iniciar-se no instante de sua queda original. Apesar da possibilidade existente na doutrina de uma resistência à tentação, de uma não-queda de um Espírito em particular, a noção da escala espírita, e a maneira pela qual os espíritas se referem aos Espíritos inferiores com que se comunicam mediunicamente, "todos já passamos por isso" ou "nós já fomos como eles", parece-me permitir claramente uma leitura no sentido da inevitabilidade da queda.

O livre-arbítrio, atributo essencial do Espírito, é assim um dispositivo de dois gumes: ele funda teoricamente a diferenciação entre essas individualidades e explica a hierarquia e desigualdade do mundo. Simultaneamente, há a noção de evolução e de progresso, leis gerais de ordenação do cosmos, que governam a trajetória dessa individualidade transcendente. Dessa maneira, o mundo hierárquico e evolutivo que o dispositivo do livre-arbítrio a um só tempo explica e gera, é anterior ao Espírito. Deus cria Espíritos permanentemente. A escala espírita pode ser vista como uma estrutura fixa pela qual os Espíritos passam, e na qual a posição de cada um é relativa à dos demais.

O livre-arbítrio e, com ele, a noção de individualidade subordinam-se às leis do progresso e da evolução. Visto dessa ótica, ambos são em si mesmos atributos incompletos do Espírito. Desenvolvem-se, adquirem-se lenta e gradualmente, conforme o grau evolutivo deste:

Nós não temos todo o nosso livre-arbítrio, só o alcançaremos quando formos Espíritos superiores, pois ele está condicionado ao compromisso, ao amadurecimento para geri-lo. Não se deixa uma criança de dois anos sozinha em casa com a janela aberta, 
ou ainda:

Deus pode impor quando o Espírito não está apto a compreender o que lhe seria mais proveitoso ( $L E$ : 143).

O determinismo espírita emerge nesse contexto como um determinismo de ordem moral, dinâmico e relacional. Como veremos ao longo deste livro, ele é um efeito da hierarquia de livresarbítrios, da limitação de um livre-arbítrio de grau menor por um livre-arbítrio de grau maior. Enquanto fonte do livre-arbítrio absoluto, Deus é também a fonte de todo determinismo. ${ }^{8}$

\subsection{A Encarnação, o Carma}

A lei da reencarnação, da necessidade de múltiplas encarnações por parte do Espírito, associada à noção de evolução, permite pensar o mundo desigual e imperfeito como essencialmente justo. Com ela, a desigualdade transforma-se numa longa caminhada para a realização de uma igualdade em bases justas:

Os Espíritos estão submetidos à lei do progresso, mas como dispõem de livre-arbítrio alcançam-na num tempo mais ou menos longo.

Ou:

Se tornarmos urna criança hotentote, de peito, e a educarmos nos mais renomados liceus, faremos dela um Laplace ou um Newton (.. .)? Temos que admitir que as almas são desiguais, e se assim o são é porque Deus assim as criou. Essa parcialidade não estaria de acordo com a sua justiça e o seu amor. (...) Admitamos o contrário, urna sucessão de existências anteriores e progressivas e tudo se explicará. (...) Com a pluralidade de existências, a desigualdade que vemos nada tem de contrária à mais rigorosa eqüidade ( $L E$ : 144-145).

Na encarnação, os Espíritos se diferenciam, através de seu livre-arbítrio, optam pelo Bem ou pelo Mal, produzindo em si mesmos o mérito ou a culpa. A encarnação está submetida à lei do carma ou da causalidade cósmica. Considerada isoladamente, a noção de carma no Espiritismo é semelhante à do hinduísmo e do budismo, implicando a percepção do mundo como um cosmos sem lacunas de retribuições éticas, no qual nenhum fato significativo do ponto de vista moral se perde (Dumont, 1970; Spiro, 1971). Segundo o Espiritismo, em cada encarnação o Espírito colhe os frutos bons ou maus de seu próprio passado. Na medida em que o conteúdo do carma é um produto do livre-arbítrio individual, cada espírito produz assim o "seu carma", como os espíritas o dizem. A loucura, por exemplo, pode ser interpretada como um "tempo de suspensão", uma paralisia como

\footnotetext{
${ }^{8}$ Agradeço especialmente a Eduardo Viveiros de Castro a discussão desse ponto.
} 
uma "dívida a ser saldada". Os males que afligem o homem nesta vida podem ter como uma de suas causas esse carma.

Mas, ao mesmo tempo que a encarnação é regida pelo mecanismo cármico, ela o é também pela lei da evolução e do progresso. Os Espíritos tendem necessariamente a progredir em cada encarnação. A possibilidade de uma retrogressão é veementemente negada; segundo os espíritas, o máximo que pode ocorrer é um Espírito permanecer estacionário. ${ }^{9}$ Cada encarnação é não só expiação, como provação, é também oportunidade de renovação que depende única e exclusivamente do mérito individual. Se o determinismo está presente na lei do carma, é o livrearbítrio do Espírito que gera o seu conteúdo. Livre-arbítrio que se renova a cada encarnação: se o Espírito sofre irreparavelmente o carma que produziu, a possibilidade de melhoria, de reparação do carma permanece sempre presente. Cada encarnação é oportunidade de evolução e de progresso. Nela, em confronto com a matéria, com a imperfeição, os Espíritos se diferenciam e se hierarquizam.

A encarnação surge então como o lugar onde se define a trajetória de cada Espírito, como o lugar onde se constrói (e se sofre simultaneamente) o carma. Vista como possibilidade de evolução, preserva-se na encarnação um espaço de indeterminação. Nesse sentido ela é um espaço decisivo de exercício do livre-arbítrio relativo que define o homem, Espírito encarnado. Como tal, ela é também o lugar do social e do outro. Exatamente porque cada vida é possibilidade de reabilitação, ela é passível de intervenção por parte dos homens: "Nem todos os problemas são irremovíveis, nem tudo é passado." Apóia-se nesse ponto a importância concedida à educação, e a relevância da ação do próprio Espiritismo, que se percebe como uma "religião do homem no mundo", pois, "se todos nos retirássemos, como poderia haver progresso, evolução?".

\section{A Noção de Pessoa no Eixo da Diacronia}

A noção de pessoa refere-se às diferentes maneiras pelas quais as diversas culturas e sociedades representam o ser humano, o indivíduo empírico. Assim, se o seu conteúdo varia culturalmente, a existência de representações sobre a pessoa é universal (Mauss, 1950; Geertz, 1978).

A pessoa é o ponto de convergência de todo esse sistema. Ela é o lugar no qual e através do qual Mundo Invisível e Mundo Visível se conectam. Nela, os dois eixos que ordenam a relação entre os dois mundos se cruzam. Examino neste item a noção da pessoa com relação ao eixo da diacronia.

\footnotetext{
${ }^{9}$ Essa visão vem reforçar a leitura da trajetória evolutiva do Espírito como tendo seu início numa queda original.
} 
A pessoa, como o Espiritismo a concebe, é uma reunião de três elementos ou componentes básicos: o corpo, o perispírito e o Espírito. Nesse sistema de pensamento, a vida de cada Espírito é, como vimos, uma sucessão de encarnações, desencarnações e reencarnações. A encarnação pode ocorrer em vários "globos habitados" dos quais a Terra é apenas um. Nela, os Espíritos revestem-se temporariamente de um invólucro material perecível, o corpo. ${ }^{10} \mathrm{O}$ corpo é animado pelo mesmo princípio que anima os seres vivos não-dotados de inteligência, o princípio vital. Esse espírito encarnado num corpo chama-se também alma.

Cada homem tem, portanto, uma natureza dupla: é corpo e alma, espírito e matéria. É o lugar composto em que o Mundo Invisível e o Mundo Visível se encontram mantendo cada qual sua particularidade. $\mathrm{O}$ espírito transcendente torna-se alma, e o corpo com seus órgãos torna-se o instrumento material de ação da inteligência que nele se encarna.

Alma e corpo estão unidos por um laço semimaterial, o perispiríto. O perispírito, juntamente com outro elemento, o fluido universal, são os mediadores nas passagens e comunicações entre os dois mundos.

O fluido universal é definido como sendo "matéria elementar primitiva" que existe em dois estados básicos:

a) de eterização ou imponderabilidade, estado que predomina no Mundo Invisível e caracteriza os fenômenos espirituais e

b) de materialização e ponderabilidade, que predomina no Mundo Visível e caracteriza os fenômenos materiais.

O fluido universal é o veículo do pensamento, sentimento, e vontade dos Espíritos, e tem "uma imensa gradação indo desde a pureza absoluta até a matéria tangível" (A Gênese, cap. XV). O corpo é fluido universal condensado e tangível, o perispírito é fluido universal numa forma imponderável e etérea. Quanto à natureza do Espírito, não foi ainda permitido aos homens conhecêla.

O perispírito compõe-se de duas partes: uma, mais grosseira que a morte, destrói libertando o Espírito, e a outra, mais sutil que o Espírito, o conserva. Desse modo, encarnado ou não, o espírito tem sempre seu perispírito, o intermediário de todas as suas sensações, o instrumento por meio do qual sua vontade se transmite ao exterior. Quando encarnado é através dele que o Espírito age sobre

\footnotetext{
${ }^{10} \mathrm{Em}$ todos os mundos os Espíritos têm corpos, pois precisam da matéria para agir sobre ela, e em todos os mundos "a forma humana com algumas diferenças e detalhes, e as modificações orgânicas exigidas pelo meio em que se tem que viver, é a mesma em todos os globos" (LM: 70).
} 
os órgãos do corpo. Quando desencarnado, o Espírito age por meio dele diretamente sobre o fluido universal:

os Espíritos atuam sobre os fluidos espirituais empregando o pensamento e a vontade: combinam, organizam fluidos dando-lhes formas e coloração determinadas (...) os fluidos são a grande oficina ou laboratório espiritual. ${ }^{11}$

Por sua vez, os Espíritos encarnados, em grau mais limitado, emitem fluidos através do pensamento e da vontade. Os fluidos, componentes de ambos os mundos, são assim os principais veículos do permanente intercâmbio que vigora entre Mundo Invisível (Espíritos desencarnados) é Mundo Visível (Espíritos encarnados).

O Espírito, eterno, é o foco da vontade, do pensamento, onde se localiza a responsabilidade individual e o sentimento de culpabilidade. O perispírito, instrumento indispensável de ação do Espírito, é também, em sua parte mais espiritual, imperecível. O corpo e a parte mais grosseira do perispírito são perecíveis, e instrumentos necessários e indispensáveis em apenas determinadas fases da vida do Espírito. A pessoa surge como um composto cujos elementos se organizam internamente de maneira hierárquica, indo do mais espiritual = eterno ao mais material = mortal.

\section{espirito}

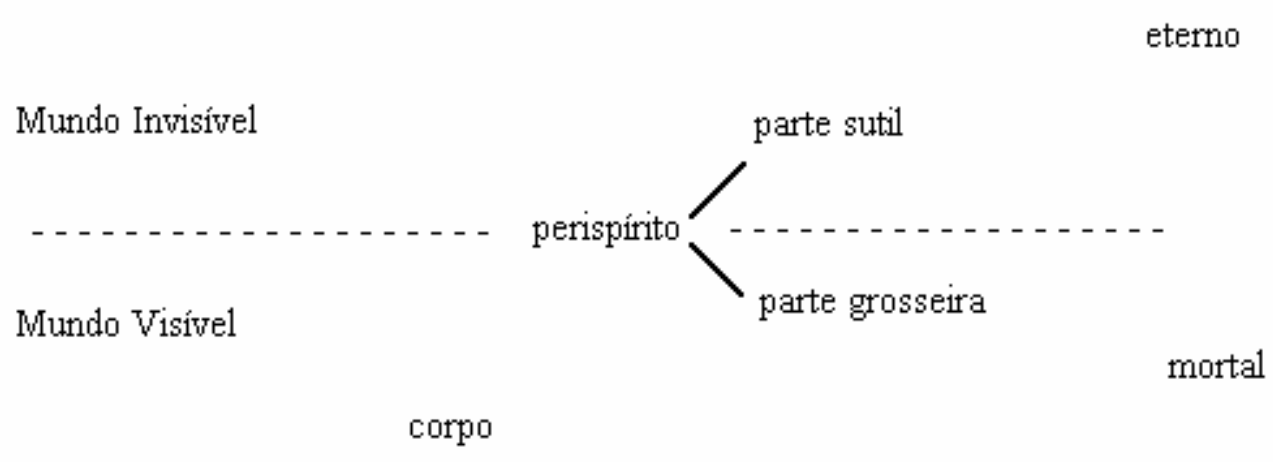

\section{Diagrama 1}

O espírito é certamente a essência do homem. É ele quem lhe confere sua definição própria, o homem não existe sem o espírito. No espírito localizam-se os atributos do livre-arbítrio, do pensamento e da vontade, que o constituem como subjetividade. Por esses atributos o espírito ganha responsabilidade e conseqüentemente o sentimento de culpabilidade. Entretanto, um mesmo Espírito, no sentido em que se trata de uma única individualidade moral, existe em três estados distintos. O homem, o agente social empírico, é do ponto de vista espírita um Espírito encarnado. A

\footnotetext{
${ }^{11}$ Apostila sobre fluidos do curso de médiuns do Lar de Tereza.
} 
vida terrena constitui-se apenas num momento efêmero de sua vida total. Ao longo de sua trajetória evolutiva, de sua Vida, um Espírito existe no estado de:

1) Espírito encarnado;

2) Espírito errante, estado desencarnado, intermediário entre duas encarnações;

3) Espírito puro, estado desencarnado não mais sujeito à encarnação

Assim, se a essência do homem é o espírito, a formulação nesse contexto da identidade da pessoa no Espiritismo requer considerações cuidadosas e uma observação de caráter geral. Na conclusão de um seminário organizado em tomo da questão da identidade, Lévi-Strauss (LéviStrauss, 1977) comenta o fato de que todas as culturas e sociedades ali examinadas, ao invés de afirmarem a noção de uma identidade substancial, fragmentam o que se considera comumente como identidade numa multiplicidade de elementos, reconstruídos a seguir das mais diversas maneiras. A noção de identidade, de algo uno, idêntico a si mesmo, revela-se claramente inadequada. $\mathrm{O}$ autor argumenta contudo pela sua preservação como uma referência indispensável para explicar uma série de coisas. Utilizando a noção de identidade nesse sentido, examino detidamente como se constroem a continuidade e descontinuidade do Espírito nos três estados de sua existência cósmica.

No eixo da diacronia, o duplo fato de ser o livre-arbítrio humano inevitavelmente incompleto e existir naturalmente submetido às leis divinas (determinismo) produz na representação da pessoa a oposição Eu maior x Eu menor.

A encarnação, o estado de Espírito encarnado, é parte decisiva da trajetória evolutiva do Espírito, do mecanismo evolutivo cármico que a regula. A gravidez é no Espiritismo um processo de materialização de um Espírito que preexiste, corresponde à aquisição por parte de um espírito de um novo corpo orgânico. ${ }^{12} \mathrm{O}$ pai e a mãe biológicos dão a seu filho apenas a possibilidade de um corpo, desempenhando a hereditariedade um papel reduzido. A reunião de diferentes Espíritos em uma família obedece a outras leis. Pela teoria das faixas vibratórias (ver o capítulo IV), é muito comum que os Espíritos encarnem em grupos. Não existindo o acaso, os Espíritos que se reúnem numa família terrena são Espíritos simpáticos, companheiros de outras encarnações, ou Espíritos antipáticos também companheiros de outra encarnação que têm entre si alguma dívida a saldar. ${ }^{13}$

No pólo oposto está a morte, que só é morte, final definitivo, do ponto de vista do corpo cujas forças se exaurem. Os espíritas nunca dizem fulano morreu, mas fulano desencarnou. Com a

\footnotetext{
${ }^{12}$ As noções de orgânico e físico são usadas no Espiritismo como sinônimo de material em oposição à de psíquico que corresponde ao espiritual.

${ }^{13}$ Esse fato explica as discórdias entre marido e mulher, pais e filhos, irmãos, provações às quais esses espíritos se acham submetidos.
} 
desencarnação a parte mais grosseira e material do perispírito se dissolve, desfazendo o laço que unia corpo e alma. A gestação e o nascimento, de um lado, e a morte, de outro, correspondem a movimentos inversos:

gestação/nascimento $=$ encarnação $=$ passagem do Mundo Invisível para o Mundo Visível $=$ união de um espírito a um corpo

morte $=$ desencarnação $=$ passagem do Mundo Visível para o Mundo Invisível = ruptura da união entre espírito e corpo.

Ambos os movimentos correspondem a um processo ou fase da Vida do Espírito que os espíritas chamam de perturbação espírita (LE: 121).

A materialização do Espírito inicia-se no momento da fecundação. ${ }^{14}$ Inicia-se concomitantemente a perturbação espírita, que perdura durante toda a gestação e nos primeiros anos da infância. ${ }^{15}$ Ao longo desse período o Espírito sofre o apagamento da memória, esquecendo todas as suas vidas pretéritas, como Espírito errante e encarnado. Essa memória transcendente ficará oculta no inconsciente, podendo vir à tona por vezes na forma de intuição. Esse período é simultaneamente um tempo de aprendizado, durante o qual o Espírito se familiariza com seu novo instrumento material, o corpo. Na desencarnação, a intensidade e duração da perturbação espírita variarão dependendo do grau de evolução do Espírito. ${ }^{16} \mathrm{O}$ processo da perturbação inverte-se, ele é agora um período de adaptação ao estado de espírito errante, puro espírito, da recuperação da memória espiritual.

Como a encarnação, o estado de espírito errante é passageiro. Contudo, nesse estado o Espírito, liberto do corpo, é a princípio mais a sua essência. É puro espírito, seus movimentos são mais livres, seus atributos mais plenos. Sua memória é idêntica ao conjunto de suas vidas. Nesse estado, o Espírito idealmente escolhe as provações por que passará em sua próxima vida encarnada. A reencarnação é uma necessidade da vida espírita:

mais cedo ou mais tarde todos sentem necessidade de avançar (LE: 121).

A cada nova encrnação o Espírito esquece o seu passado. Entretanto, nessa nova vida, o perispírito, elemento central para a compreensão das sucessivas passagens que o Espírito empreende entre os dois mundos, funciona como "um molde do corpo". Ele é o registro de todas as vidas pretéritas: tudo a que o Espírito submeteu seu organismo físico, desde as mais variadas

\footnotetext{
${ }^{14} \mathrm{O}$ aborto provocado, interrompendo esse processo, é veementemente condenado. Ver por exemplo, a esse respeito “Abordando o Aborto", in O mundo Espírita, 30 de junho de 1980.

${ }^{15}$ Segundo Kardec ela termina aos sete anos de idade

${ }^{16}$ Com o Espiritismo, por exemplo, o Espírito, compreendendo antecipadamente a experiência com a qual se defrontará, sofre menos.
} 
emoções e atitudes até todos os tipos de vícios, nele se inscrevem. O determinismo do carma estará assim presente em cada nova vida do Espírito em dois planos:

a) ao nível da matéria, do corpo e

b) ao nível das situações concretas em que o Espírito encarnado se verá envolvido - a família em que nasce, sua riqueza ou pobreza, as relações que travará ao longo da vida. Todavia, o esquecimento do passado preserva, segundo o Espiritismo, um espaço de indeterminação que garante a possibilidade de exercício do livre-arbítrio humano:

a fatalidade existe no tocante à posição do homem na Terra e às funções que nela desempenha como conseqüência do gênero de existência que o Espírito escolheu, como prova, expiação ou missão. Sofre ele, de maneira fatal, todas as vicissitudes desta existência e todas as existências boas ou más que lhe são inerentes. Mas a isso se reduz a fatalidade, porque depende de sua vontade ceder ou não a essas tendências. Os detalhes dos acontecimentos estão na dependência das circunstâncias que ele mesmo provoque com seus atos, e sobre os quais podem influir os Espíritos através dos pensamentos que lhe sugerem. A fatalidade está, portanto, nos acontecimentos que se apresentam ao homem como conseqüência da escolha da existência feita pelo espírito, mas pode não estar nos resultados desses acontecimentos, e jamais se encontra nos atos da vida moral (LE: 348).

O esquecimento do passado é um artifício que atualiza e renova o livre-arbítrio do Espírito encarnado. No plano do espírito há um espaço de indeterminismo, no plano da matéria o determinismo do carma. Sendo que o exercício do livre-arbítrio altera e constrói permanentemente o conteúdo do carma de cada espírito. A maneira pela qual o Espírito enfrentará sua nova vida, como todos os determinismos que ela comporta, permanece assim em aberto, dependerá de seu esforço, de sua vontade, de seu mérito, enfim. A encarnação tem a qualidade de uma provação. A vida encarnada é provação e, por isso mesmo, essencial para o progresso do Espírito. Todavia, nela os Espíritos (os espíritas) são apenas seu Eu menor, ou seja, parte de sua essência. Os espíritas opõem ao Eu menor, à identidade dessa encarnação, o Eu maior, termo que designa os dois outros estados de existência do Espírito:

1. O Espírito puro, a identidade plena e final do Espírito, que só se realizará ao final de sua trajetória, quando o Espírito deixar definitivamente o Mundo Visível, não precisando mais reencarnar. Do ponto de vista terreno, essa identidade final é irrealizável. Na encarnação, esquecido de seu passado e, por definição, no percurso de sua evolução, o Espírito é sempre $E u$ menor.

2. O Espírito errante. Em sua vida desencarnada, no Mundo Invisível, o Espírito prossegue seu aprendizado e participa, através da comunicação espiritual, decisivamente dos acontecimentos 
do Mundo Visível, dedicando-se às causas do Bem ou do Mal. ${ }^{17}$ Esse estado de espírito errante não é provação, não é possibilidade de progresso como a encarnação o é. Nesse sentido, ele escapa ao mecanismo cármico. Trata-se antes de um descanso, de um preparo para a nova encarnação. Nele o Espírito é mais a sua essência, porque é puro espírito, sem corpo. Todos os seus atributos estão mais livres e agem mais facilmente. Sua memória é idêntica ao conjunto de suas vidas. O livre-arbítrio, atributo essencial do Espírito, existe em ambos os estados. No de Espírito errante manifesta-se claramente na escolha da nova vida, das provas a serem nela enfrentadas. No de encarnado existe na

faculdade de ceder ou resistir aos arrastamentos a que voluntariamente estamos submetidos (LE: 347).

O ponto máximo da trajetória evolutiva, o estado de Espírito puro, que corresponde à plenitude da identidade do Espírito, ao máximo de livre-arbítrio e de afirmação da individualidade, é simultaneamente a sua negação. O Espírito puro não está mais sujeito à encarnação, iguala-se a Deus no sentido em que passa a transcender a oposição entre os dois mundos, reintegrando-se e desfazendo-se no Todo, na Indistinção, na Plenitude, na Perfeição. Reproduz-se na representação da pessoa a tripartição do universo assinalada anteriormente.

A pessoa nesse sistema constrói-se tendo como referência um conjunto de planos que pode ser representado pelos seguintes esquemas:

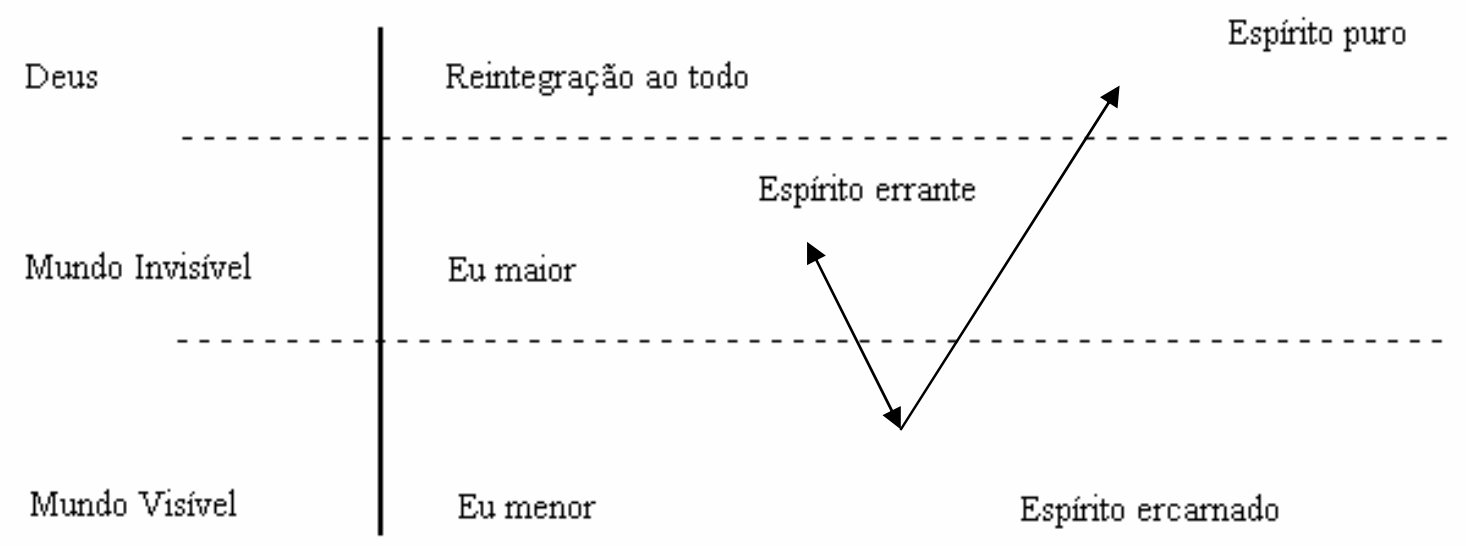

Diagrama 2

\footnotetext{
${ }^{17}$ Ver a esse respeito o livro do Espírito André Luiz, psicografado por Chico Xavier, Os Missionários da Luz.
} 
Eu Maior

Eu Menor

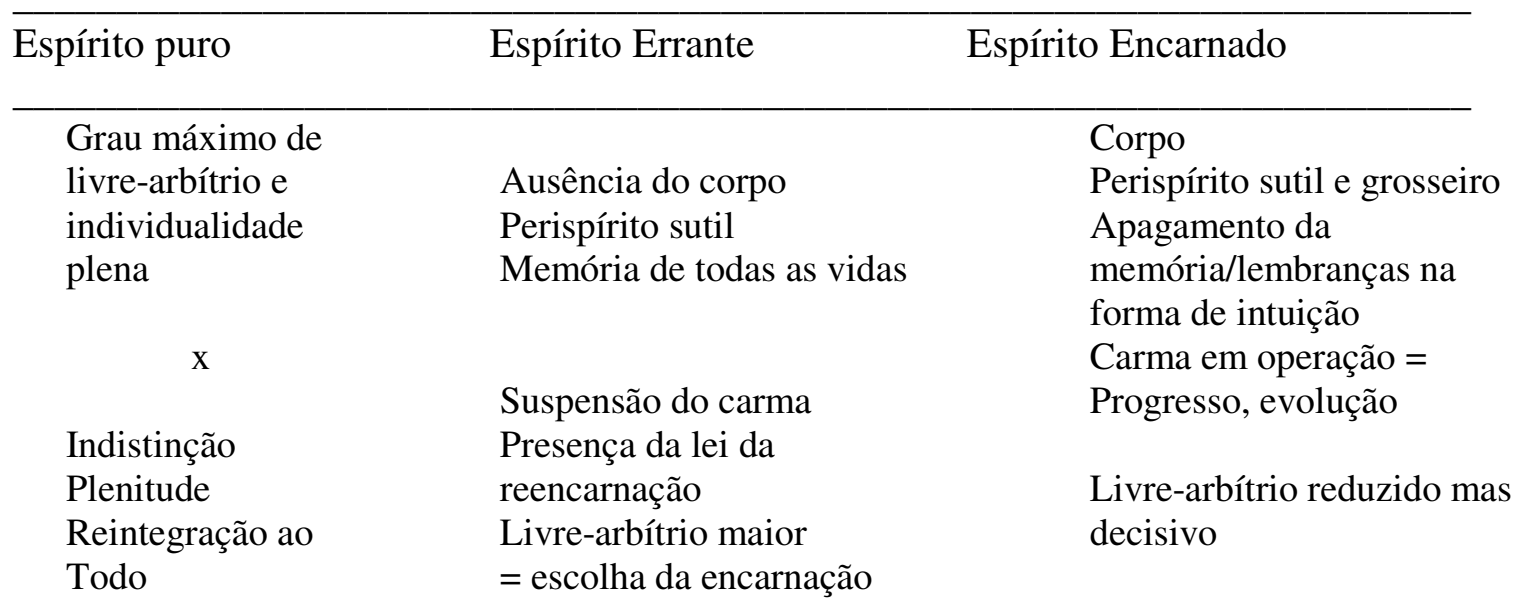

\section{Diagrama 3}

Cabe, entretanto, ressaltar que esse esquema abstrai um dado decisivo que nuança algumas das oposições que aparecem aí claramente demarcadas - a lei da evolução. Como disse inicialmente, a lei da evolução faz com que tanto o Mundo Invisível como o Mundo Visível se hierarquizem ambos numa escala a que vai o puro, espiritual, sagrado, ao impuro, material profano. Um Espírito errante não é assim necessariamente superior a um Espírito encarnado. O perispírito como elemento mediador e registro das encarnações é um elemento decisivo nessa hierarquização: sua densidade é mais sutil ou mais grosseira conforme o grau da evolução individual e a natureza do mundo em que habita. Nos Espíritos moralmente elevados, sua sutileza permite que esses, quando desencarnados, se vejam logo livres dos obstáculos que o corpo representa. Nesse caso, seus atributos manifestam-se mais livremente. Nos Espíritos inferiores a sua proximidade da matéria determina a persistência das ilusões da vida terrena, implicando a redução de seu livrearbítrio. O Espírito inferior passará então, no estado de desencarnado, por um processo que, restaurando o seu livre-arbítrio através do arrependimento, o tornará apto a reencarnar, a escolher sua nova existência de provações (ver o capítulo IV).

Outra questão crucial foi deixada momentaneamente de lado nessa discussão, a da relação do Espírito encarnado com outros Espíritos, da comunicação espiritual, da mediunidade que será examinada no capítulo IV. 


\section{O CENTRO E O SISTEMA RITUAL ESPÍRITA}

Em conversas com espíritas escutei várias vezes a idéia de que

santidade, sacerdócio, ritual e magia são coisas que no Espiritismo não tem.

No salão da FEERJ, onde assistia às palestras do ICEB, havia um pequeno quadro pendurado na parede com os seguintes dizeres:

O Espiritismo não tem Ritual: a prática espírita não tem ritual, símbolos nem fórmulas especiais. O Espiritismo é uma doutrina de simplicidade e naturalidade. De acordo com a codificação de Allan Kardec não se pode introduzir no Espiritismo qualquer objeto de culto exterior (...).

Como então falar em ritual num sistema religioso expressamente anti-ritualista?

Mary Douglas, em seu livro Natural Symbols, faz uma breve discussão do antiritualismo religioso, cuja história no Ocidente pode ser datada da Reforma Protestante. A utilização da noção de ritual pelos espíritas pode ser vista como um capítulo dessa história. Ela é parte da construção de sua identidade religiosa. Os espíritas entendem ritual num sentido partidário, como sinônimo de conformidade vazia, de atos cuja seqüência se repete mecanicamente sem se saber por que ou para quê. Nesse contexto, a noção de ritual tal como entendida pela Antropologia Social tem um sentido neutro, não dependendo do compromisso ou não-compromisso dos atores com os atos praticados (Douglas, 1970: 20). ${ }^{1}$

O anti-ritualismo espírita, contudo, lança luz sobre uma característica central do Espiritismo. Ao distinguir entre um "culto externo", equivalente ao "cerimonial, às prescrições de adoração", e um "culto interno" correspondente ao "ato de consciência sem medo ou interesse materiais", e ao valorizar negativamente o primeiro e positivamente o segundo, o Espiritismo elege como foco de sua ação a pessoa moral. Ao enfatizar a consciência, o compromisso pessoal verbalmente explicitado, seu objetivo primeiro é a transformação do indivíduo (no sentido empírico). Esse processo é um meio para alcançar o fim último a que essa religião se propõe: a evolução dos Espíritos e, com ela, o progresso da humanidade. Em termos sociológicos, esse processo corresponde à construção de determinado sujeito moral, a determinada representação da pessoa.

Hubert e Mauss, em "Essai sur la nature et la fonction du sacrifice" (Mauss, 1968), entendem o ritual como um mecanismo que aciona o conjunto das coisas sagradas às quais

${ }^{1}$ Para uma discussão do conceito de ritual, ver o capítulo 11. 
se dirige, relacionando os dois planos constitutivos da vida religiosa - o sagrado e o profano -, franqueando passagens entre esses domínios complementares. O sistema ritual espírita, ao afirmar e estabelecer o circuito de relações entre o Mundo Visível e o Mundo Invisível, é uma instância decisiva da construção do sujeito espírita. A partir dessa perspectiva, este capítulo inicia a análise desse sistema ritual. Não se trata, porém, de examinar cada ritual particular. Procedo, num primeiro momento, a uma breve etnografia do centro e ao exame de sua hierarquia religiosa. Num segundo momento, discuto o significado de três categorias do discurso espírita, por meio das quais os espíritas classificam suas sessões: o estudo, a caridade e a mediunidade.

\section{O Centro Espírita}

Se o centro espírita é apenas um elemento de um conjunto maior que os espíritas denominam Movimento Espírita, ele é o lugar mais indicado para a prática da doutrina em sua totalidade. Do ponto de vista da sincronia, o centro é o lugar privilegiado para a mediação entre o Mundo Visível e o Mundo Invisível. Ele representa, no Mundo Visível, o lugar mais puro. É um:

lugar à parte, aquele lugar em que Jesus dizia que devíamos orar, um lugar elevado.

No início da penetração do Espiritismo no Brasil (fins do século passado), e pelo que o discurso do grupo pesquisado permite perceber, realizavam-se sessões mediúnicas nos lares. ${ }^{2}$ Atualmente a orientação da Federação é a de que tais sessões sejam evitadas. ${ }^{3}$ Nos lares incentiva-se o "culto do evangelho no lar", reunião que consiste numa prece, na leitura e estudo de pequeno trecho do Evangelho segundo o Espiritismo. Configura-se uma oposição casa/centro relacionada à tendência no sentido da uniformização e controle no seio dessa religião. No entanto, no grupo pesquisado eram freqüentes os estudos mediúnicos, sessões de irradiação, ${ }^{4}$ reuniões de estudo doutrinário, bazares de caridade em algumas casas. Seus organizadores e participantes estão sempre vinculados a um centro, que se constitui assim no foco legitimador e articulador de uma rede de relações que reúne diferentes casas. A ampliação das atividades e dos freqüentadores de uma casa pode gerar um novo centro. O Lar de Tereza, por exemplo, nasceu dessa maneira.

O Lar de Tereza é um centro ou casa espírita como é também chamado. Seus dois lemas são:

\footnotetext{
${ }^{2}$ Os espíritas cujos pais também o eram referiam-se à ocorrência de sessões mediúnicas em suas casas. ${ }^{3}$ Essa orientação era seguida tanto no Lar de Tereza como no André Luiz.

${ }^{4}$ As sessões de irradiação são reuniões de prece e vibrações em benefício de Espíritos encarnados e desencarnados (ver o capítulo IV).
} 
Espíritas! Amai-vos, este o primeiro mandamento.

Instruí-vos, este o segundo ( $O$ Espírito da Verdade)

Fora da caridade não há salvação! (Allan Kardec).

Foi inicialmente, de 1951 a 1969, um culto do evangelho no lar, funcionando em Copacabana, na casa de sua atual presidente, que era então colaboradora de outro centro espírita, a Cabana de Antônio de Aquino, localizada na Tijuca. Ao longo desse período, suas atividades ampliaram-se. Em 1969 registrou-se oficialmente como "Instituição Espírita Cristã de Estudo e Caridade". Em 1973 mudou-se para o pequeno prédio, em Ipanema, no qual funciona até hoje. ${ }^{5}$

Os organizadores do Lar de Tereza são em sua grande maioria mulheres, em geral aposentadas ou donas-de-casa que em alguns casos preferiram largar o trabalho fora para dedicar-se ao centro. Algumas encontram-se diariamente no centro, outras revezam-se durante a semana de acordo com a tarefa que desempenham. As portas do centro encontram-se geralmente abertas, guardadas por um porteiro, que é também faxineiro e ajudante em múltiplos serviços, ou por algum cooperador. O movimento de pessoas nos horários de sessões públicas é grande, nos de sessões privadas menor. Nos horários em que não há sessões (hora de almoço, intervalo entre sessões, sábado à tarde e domingo) encontram-se lá sobretudo as organizadoras, trabalhando na programação de alguma tarefa, discutindo algum assunto pendente, arrumando a secretaria ou simplesmente conversando e contando casos.

Além do Lar de Tereza, há no mesmo prédio, no andar térreo, um bazar de caridade, organizado por vários centros espíritas que nele se revezam durante o ano, e, no terceiro andar, uma creche espírita. O centro ocupa todo o segundo andar, a parte interna do térreo, e o terceiro quando está vago. No segundo andar encontra-se uma pequena secretaria, onde funciona também uma biblioteca de livros espíritas. É a Biblioteca João de Deus (numa homenagem à visita do papa João Paulo II ao Brasil, ocorrida em 1980). Nela os espíritas, ou qualquer interessado, podem retirar para consulta e leitura os livros que desejarem. Ainda no segundo andar há uma sala grande, usada geralmente nas sessões públicas, uma sala menor, usada nas sessões privadas, e um banheiro aos fundos. No térreo funciona a Livraria Irmão $\mathrm{X},{ }^{6}$ especializada em livros espíritas. Antes e depois das sessões há sempre

\footnotetext{
${ }^{5} \mathrm{O}$ prédio é cedido por um comerciante espírita proprietário de lojas em Copacabana.

${ }^{6}$ Irmão X é um pseudônimo do Espírito Humberto de Campos. O pseudônimo foi adotado pela Federação para designar as obras desse Espírito psicografadas por Chico Xavier após um caso com os herdeiros de um
} 
gente na livraria, examinando e comprando livros ou simplesmente conversando. No final do corredor há uma sala, uma pequena cozinha, varanda, banheiro e um depósito. Nesse local realizam-se tanto algumas sessões como bazares e lanches, ocasiões informais e caracteristicamente femininas quando se conversa à vontade sobre qualquer assunto.

O aspecto do centro é sóbrio. Suas paredes são azul-claro, "cor que pacifica o ambiente" ${ }^{7}$. As janelas existentes são cobertas por cortinas acinzentadas, ou por papel azulclaro colado nas vidraças. O mobiliário é simples, composto de cadeiras, mesas, um piano e um quadro-negro. As diferentes sessões espíritas exigem pouca parafernália. Os objetos rituais utilizados são basicamente cadeiras, mesas, relógios, copos com água que será fluidificada pelos Espíritos ao longo da sessão, e por vezes, dependendo da sessão, papel e lápis, vitrola, piano e quadro-negro. Como o espaço disponível é pequeno, sua definição e organização modificam-se permanentemente. Dispõem-se as cadeiras em círculos ou em filas. Arrumam-se pequenos conjuntos de mesas e cadeiras. Arma-se um biombo aos fundos para criar um espaço reservado. Arrumam-se grandes mesas cercadas de cadeiras. Embora a princípio as sessões públicas ocorram na sala central e as privadas nos aposentos menores, esses espaços são continuamente redefinidos pelo significado particular das sessões que neles se realizam. ${ }^{8}$

O início de uma sessão requer a existência de um ambiente espiritual adequado, garantido pela conduta e ação dos espíritas, pelos procedimentos rituais da fase inicial das sessões e pelo concurso de forças espirituais amigas e protetoras. Entre estas últimas estão notadamente o dirigente e os amigos espirituais do centro, entidades que protegem e orientam o trabalho que lá se faz. O dirigente espiritual do Lar de Tereza é Bezerra de Menezes. ${ }^{9}$ Os principais amigos espirituais do centro são Tereza e Antônio de Aquino, ${ }^{10}$ Espíritos que trabalhavam no centro de origem da presidente e acompanharam a fundação do novo centro. Duas horas antes de cada reunião, essas entidades, segundo os espíritas,

caso com os herdeiros de Humberto Campos, que tentaram reivindicar direitos autorais sobre a venda dos livros.Ver a esse respeito Miguel Timponi, A psicografia perante os tribunais.

${ }^{7}$ Não há nenhuma norma nesse sentido. O azul ou verde claro é, contudo, a cor usual dos centros. Conforme me explicou a presidente do Lar de Tereza, o ambiente e pouco convidativo aos Espíritos Inferiores, chegados à escuridão e às sombras.

${ }^{8}$ Os centros maiores, como era o caso do GEAL, dispõem de aposentos exclusivos a cada tipo de sessão.

${ }^{9}$ Bezerra de Menezes foi médico e deputado federal do Império. Foi presidente da Câmara Municipal do Rio de Janeiro de 1878 a 1881, e presidente da Federação Espírita Brasileira de 1895 a 1900. Ver a esse respeito Brito Soares, Vida e Obra de Bezerra de Menezes. Rio, FEB, 1962. A atuação de Bezerra de Menezes é considerada importante para a extensão e unidade dos grupos espíritas. Ver Renshaw, 1969, p. 131.

${ }^{10}$ Tereza é a santa católica Terezinha do Menino Jesus, ou Terezinha de Lisieux, que viveu de 1873 à 1897 em Lisieux na França, e foi canonizada em 1905. Tereza entrou para o Carrnelo aos 15 anos, onde escreveu A História de uma Alma, revelando um caminho simples e humilde de santidade. Após sua morte, Lisieux tornou-se um importante centro de peregrinação, famoso por suas curas milagrosas. Antônio de Aquino foi, segundo os espíritas, um padre católico brasileiro famoso por suas curas. Como me disse uma informante, ao contrário de Tereza, que raramente aparece, Antônio de Aquino comunica-se regularmente em sessões mediúnicas. 
fazem uma "faxina espiritual" no ambiente, retirando forças negativas e participam decisivamente das sessões. Em todas as paredes há dois ou mais pontos de luz com pequenas lâmpadas azuis. Nos momentos em que a comunicação com o mundo espiritual se toma ostensiva, as luzes se apagam, acendem-se as lâmpadas azuis e o ambiente fica imerso na penumbra. Segundo os espíritas, com a luz normal os fluidos, veículos da comunicação espiritual, se dispersam ou se queimam. A pontualidade é extremamente valorizada. Há grandes relógios nos aposentos principais, apenas muito raramente as reuniões ultrapassam o prazo de duração estipulado. Na sala central, além do piano, da vitrola e do quadro-negro, há nas paredes dois discretos quadros, um de Jesus com as mãos sobre a cabeça de uma criança dando um passe no entender dos espíritas, outro de Tereza, e uma pequena caixa de madeira com duas pequenas aberturas na parte superior onde se lê ENCARNADOS e DESENCARNADOS, na qual os freqüentadores das diferentes sessões depositam os nomes de seus parentes e amigos, falecidos ou não, para quem solicitam ajuda espiritual.

Todo centro espírita comporta um determinado número e tipo de sessões. Há modelos expressamente sugeridos pela Federação aos centros. ${ }^{11}$ Contudo, mesmo existindo normas comuns, um centro não oferece necessariamente todas as sessões do repertório espírita, e a maneira pela qual essas sessões se organizam e se combinam pode variar bastante. ${ }^{12}$ Os espíritas como vimos, explicam essas diferenças pelo fato de o dirigente espiritual ter a sua individualidade. Mesmo internamente, é comum a ocorrência de pequenas alterações na organização das sessões em tomo de um eixo básico: divide-se uma turma em dois, ou em dois grupos que se revezam quinzenalmente; organiza-se uma sessão destinada apenas a estudos mediúnicos; inaugura-se uma sessão especial para passes. $\mathrm{O}$ modelo com que trabalho baseia-se na maneira pela qual as sessões se organizavam durante o ano de 1980.

O ciclo ritual espírita tem como unidade básica a semana. Todas as sessões são oferecidas semanalmente, algumas em dois turnos. Quando isso é impossível, há um revezamento semanal entre os grupos que a freqüentam. $\mathrm{O}$ tempo transcorre linearmente, havendo apenas algumas comemorações, geralmente palestras, em datas especiais como a da publicação do Livro dos Espíritos, da desencarnação de alguns espíritas famosos. No

\footnotetext{
${ }^{11}$ Ver, por exemplo, Orientação aos Centros Espíritas. FEERJ, 1980.

${ }^{12}$ Algumas sessões que existiam no Lar de Tereza não existiam no André Luiz e vice versa. Outras mostravam em sua organização diferenças significativas. No Lar de Tereza, Por exemplo, as Reuniões Públicas de Estudo Doutrinário comportavam ao final um passe coletivo. No André Luiz, após essa mesma reunião, os presentes que desejassem tomar passe formavam uma fila para entrar numa "sala de passes", na qual receberiam passes individuais.
} 
Natal realizam-se grandes bazares de caridade, distribuições de presentes aos pobres, e os jovens apresentam uma peça teatral.

\subsection{A Hierarquia de Potencial}

O centro compõe-se formalmente de uma diretoria, conselho fiscal e consultivo, tesouraria e secretaria-geral e um corpo de sócios. Mantém-se através de contribuições voluntárias e fundos levantados em campanhas, bazares e lanches. Organiza-se em quatro departamentos: programação doutrinária e orientação mediúnica, serviços assistenciais, divulgação, e infância e mocidade, sendo seus responsáveis nomeados pela diretoria.

Cada departamento é um núcleo de tarefas, suas diretoras têm uma reunião mensal com a presidente e reuniões com os dirigentes dos subgrupos do setor. Os dirigentes dos subgrupos, por sua vez, têm reuniões com os colaboradores de tarefas específicas. Em todos esses níveis, num grau crescente de poder e responsabilidade, quem ocupa um cargo de direção deve supervisionar todas as tarefas coordenadas por seu núcleo.

Entretanto, essa descrição formal da estrutura e organização do centro está longe de dar conta de seu funcionamento efetivo. Formalmente, por exemplo, existe uma diretoria, na prática a direção do centro é individualizada na figura de sua presidente ou diretora. Como me disse a diretora de um dos departamentos:

Não somos uma empresa, uma firma. As coisas não podem ser vistas dessa maneira.

Renshaw (Renshaw, 1969: 103) afirma que,

conforme as normas gerais do movimento, a estrutura do centro se caracteriza:pela simplicidade, voluntarismo e personalismo.

e Camargo (Camargo, 1961: 117) vê

a natureza democrática do grupo espírita como representando um valor dos urbanistas socialmente ascendentes e a rejeição da organização tradicional da sociedade.

De fato, o funcionamento do centro parece extremamente flexível e informal. As pessoas não são nunca mencionadas a partir de seus cargos, mas de seus nomes, os dirigentes e diretores de departamento hesitavam antes de se designarem para mim como tais estou te dando um nome, não sei se é bem isso,

ou ainda:

é só para dar um nome aos bois porque sou igual aos outros e faço de tudo o que precisa. 
De fato, todo espírita tem potencialmente acesso a todas as posições no centro, e, de fato, a presidente ou as diretoras de departamentos fazem de tudo, desde arrumar uma sala até dirigir uma sessão. Essa percepção todavia é superficial, e dissocia o aspecto organizacional do centro do conteúdo do sistema de crenças espírita.

No plano das representações espíritas, a distribuição e divisão de tarefas no centro é regida pela noção de hierarquia de potencial, pois não há no Espiritismo "posições sacerdotais" ou "hierarquia no sentido ritualístico". Essa noção dá conta de uma dimensão relevante do funcionamento do centro, e ancora-se nas representações espíritas acerca da pessoa.

A construção dessa hierarquia é vista como tendo seu início no encaminhamento das pessoas para as tarefas existentes. Os espíritas perceber esse processo como correspondendo à adequação entre as necessidades do centro e o julgamento da presidente, ou dirigente de núcleo específico de tarefas, de um lado, e a escolha, vontade e capacidade do participante de outro. A diretora de um dos departamentos descreveu-me assim seu ingresso no centro:

Eu cheguei aqui, era professora. Vi as crianças na evangelização. Interessei-me. A pessoa pergunta: "Qual o programa da casa, como posso me situar?", e procura se colocar conforme seus recursos.

Na reunião de jovens, na mesa mediúnica, nos estudos doutrinários, os espíritas, na medida em que progride a sua socialização nesse sistema de crenças, vão sendo classificados e encaminhados para tarefas específicas.

Como em todas as atividades humanas há os que vão se destacar.

Nesse movimento funda-se uma hierarquia sim, mas que os espíritas pensam como nascida do mérito, da moral individual, nas próprias circunstâncias do trabalho, uma hierarquia de potencial.

Nesse modelo há duas regras básicas:

1. a da "não-interferência no trabalho do outro". O desempenho de uma tarefa é visto como uma coisa pessoal. Assim, dentro dos limites da doutrina, uma tarefa pode ser cumprida da maneira que a pessoa em questão julgar mais conveniente. E aquele a quem cabe a iniciativa tem, por direito, o primeiro lugar, i.e., é quem dá as diretrizes de sua realização.

Trata-se de

uma conquista, fruto de luta e esforço que representa apenas responsabilidade. 
Portanto, a presidente do centro, em cuja casa este nasceu, ocupa incontestavelmente o primeiro lugar na hierarquia terrena, encontrando-se subordinada apenas ao dirigente espiritual do centro e ao plano espiritual como um todo, a cujo serviço o centro se coloca e que comanda, na visão dos espíritas, todas as atividades.

2. "não prender mas soltar". Na medida em que o processo de socialização no Espiritismo se desenvolve, os dirigentes dão, gradualmente, sempre mais autonomia a cada pessoa no desempenho de sua tarefa. As atribuições diretas do dirigente restringem-se, embora ele permaneça a par de tudo o que ocorre em sua alçada. Na reunião dos jovens, por exemplo, a

diretora do departamento de infância e juventude participa diretamente de todas as tarefas realizadas com o primeiro ciclo. No terceiro ciclo, os jovens "já têm seus próprios líderes", e são estes que coordenam os núcleos de tarefas. A diretora apenas orienta e supervisiona.

Entretanto, Como me disse a diretora desse departamento,

há o problema diz interferência. É claro que vai haver o conflito, mas você joga com ele.

o conflito existe porque

aqui no centro o trabalhador é também a pessoa necessitada. É o doente colocamos junto ao doente para se curar.

Para garantira ordem há necessariamente

um número menor de pessoas que tem de estar de olho em tudo isso. Leva algum tempo até ela se superar e fazer parte desse pequeno grupo que não vai.mais dar problemas.

Esse "pequeno número" corresponde àqueles que ocupam os cargos de maior responsabilidade no centro.

Esse modelo concilia um espaço para o desempenho pessoal com um espaço de determinações e necessidades do centro. A hierarquia não só é, como deve ser permanentemente, a expressão de valores pessoais. Esses valores são vistos como preexistentes. As potencialidades e possibilidades são inerentes a cada Espírito encarnado, a sua individualidade. Nas circunstâncias do trabalho elas se manifestam. A hierarquia é então fruto de um exercício da vontade e do livre-arbítrio do Espírito encarnado. Como no Mundo Invisível, ela é essencialmente justa, pois repousa exclusivamente sobre a ordem moral.

Ao contrário do que ocorre na Umbanda, onde, como a análise de Yvonne Velho (Velho, Y; 1975) o demonstra, o conflito ocupa um lugar central, dando conta do 
surgimento de novos terreiros, e presente nas representações através da categoria demanda, o Espiritismo se caracteriza por valorizar a harmonia, o respeito às posições estabelecidas, a tolerância, o controle. Desvaloriza-se em contrapartida a rebeldia, o conflito e o descontrole de maneira geral. Durante todo o meu trabalho de campo no centro, presenciei apenas quatro pequenos incidentes. ${ }^{13}$ Todos obedeciam a um mesmo padrão. Ocorriam sempre entre pessoas que ocupam na hierarquia do centro, ou estavam ocupando na situação em particular, posições desiguais. Todos, partindo do inferior para o superior, fundavam-se no não-reconhecimento, expresso de modo mais ou menos direto, da autoridade deste último para o exercício de determinada atribuição, reconhecimento crucial para o funcionamento do sistema. O próprio fato da manifestação de descontentamento, oposição, irritação por parte de quem abre a discussão tende a ser lido como indício de "inferioridade", de "imperfeição". A reação do superior, idealmente paciente e firme, reafirma sempre a sua superioridade moral e conseqüentemente as posições estabelecidas. Todo desvio ou diferença pode ser lido como sintoma de inveja, ciúmes, mesquinhez, egoísmo, em suma, sentimentos reprováveis traduzíveis como sinais de inferioridade moral/espiritual: todo conflito potencial é assim neutralizada o, subjazendo a esse movimento o reconhecimento reafirmação do lugar que cabe a cada um, segundo o mérito individual, a hierarquia do centro que reproduz em escala reduzida o universo.

Se no plano das representações espíritas explícitas essa hierarquia é a expressão legítima do valor pessoal e moral de cada um, num outro plano de análise os princípios que a regem obedecem à lógica desse sistema de crenças. Em outras palavras, esse valor pessoal e moral que se revela está condicionado pelas regras do sistema ritual espírita.

\subsection{A Classificação dos Agentes Rituais}

As organizadoras do Lar de Tereza distinguem os que vão ao centro em duas grandes categorias: os freqüentadores, "que vêm ouvir e participar", e os cooperadores, "que colaboram nas tarefas". Essa distinção é recoberta por outra que os espíritas efetuam entre reuniões feitas com as portas abertas, e reuniões feitas com as portas fechadas, às quais só se assiste com a devida autorização e qualificação. Freqüentadores e cooperadores como um todo podem ser considerados "freqüentadores" no sentido em que se opõem a um outro grupo não explicitamente nomeado como tal pelo discurso espírita, mas que acredito poder individuar para os fins da análise, os "não-freqüientadores".

\footnotetext{
${ }^{13}$ Ver Anexo 1, página 68.
} 
Essas distinções podem ser pensadas a partir da oposição binária entre o Externo, pólo no qual se alinham os não-espíritas e a rua, e o Interno, pólo associado aos espíritas e ao centro. Este último pólo, por sua vez, se subdivide sucessivamente num Externo e num Interno. A classificação dos agentes rituais no centro espírita pode ser representada pelo seguinte esquema:

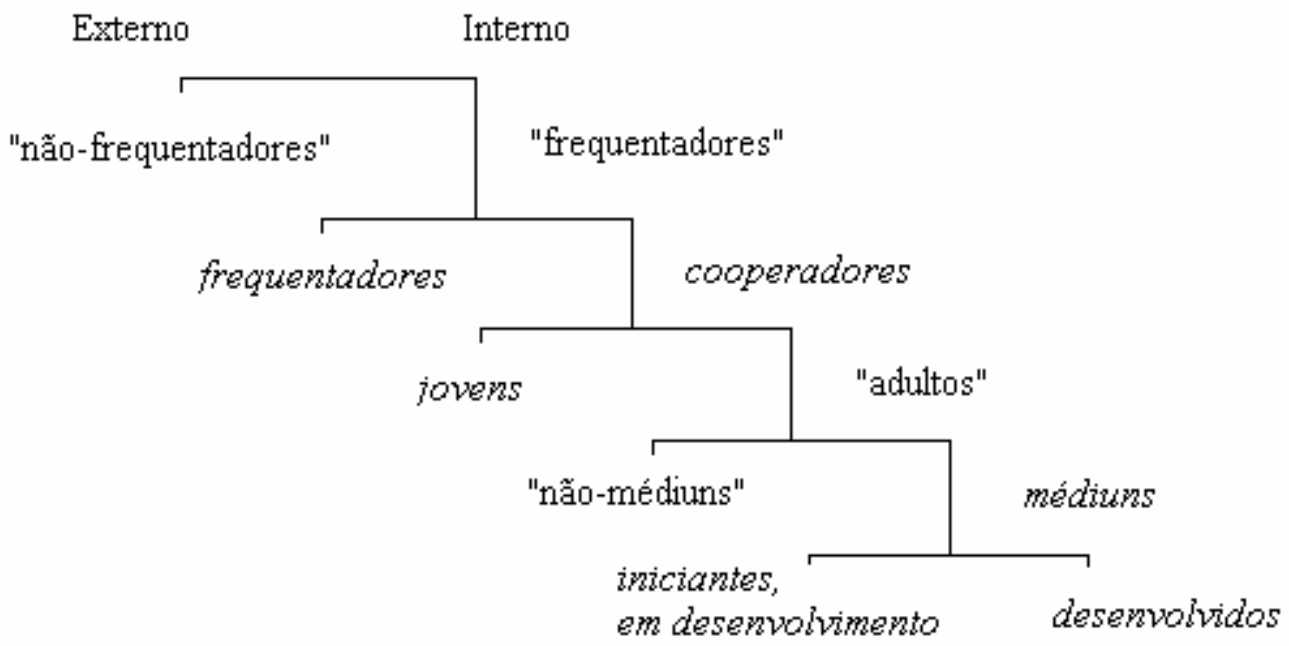

\section{Diagrama 4}

O grupo dos "não freqüentadores" refere-se à não totalidade dos Espíritos desencarnados, à humanidade em geral. Não há no globo recanto inacessível ao poder da ação e do pensamento espíritas que, por meio da prece, das vibrações e do concurso das pessoas espíritas chagam a qualquer parte. Desse conjunto destaca-se uma parcela dos homens que é objeto das tarefas de beneficência: os velhos, órfãos, presos, doentes, os pobres de maneira geral. Esse grupo menor estabelece com a humanidade uma dupla relação simbólica, metonímia e metafórica. Ele envoca o todo que é parte e, ao mesmo tempo, qualifica-o como enfraquecido e carente. Como veremos, ele ocupa nesse sistema um lugar importante.

Os freqüentadores são uma categoria mediadora entre o Externo e o Interno maiores, entre os não-espíritas e os espíritas. Não-espíritas podem tomar-se espíritas, e toda a estratégia de atendimento a esse grupo visa sua transformação em cooperador. Trata-se, de um lado, de uma terapia ocupacional, que, segundo a presidente do centro, consiste em encaminhar os que procuram o centro, paralelamente às sessões que lhes são destinadas, às tarefas existentes. Por outro lado, trata-se de uma tarefa de conscientização que visa tornar explícita a colaboração insuspeita cor o mundo espiritual que todo homem realiza, inscrevendo o homem conscientemente no circuito de trocas e passagens entre o Mundo 
Visível o Mundo Invisível, no qual todos vêm e vão, dão e recebem. Esse grupo é objeto de um núcleo ritual próprio, que consiste nas reuniões públicas, atendimento fraterno, nas reuniões e tratamento.

Os jovens reúnem-se nas reuniões da juventude e colaboram nas diferentes tarefas espíritas. A existência mesma dessa categoria indica a oposição jovem x adulto, espírita não-pleno x espírita pleno. Como não-adultos, pessoas não plenas, os jovens são também espíritos não- plenos. Estão cumprindo uma primeira fase tida como necessária e conveniente para o estudo doutrinário. $\mathrm{O}$ acesso ao desenvolvimento da mediunidade lhes é desaconselhado ${ }^{14}$. A não ser entre os próprios Jovens, que em seus líderes, eles não têm acesso às posições de maior autoridade no centro.

Esse centro é, como já disse, organizado sobretudo por mulheres. ${ }^{15}$ Porém, excluindo-se as organizadoras homens e mulheres participavam igualmente das tarefas. A oposição mais importante entre os cooperadores adultos é a entre médiuns e não-médiuns. Esse é um ponto delicado ao qual retomarei ainda adiante. Segundo o Espiritismo, todo homem é, como vimos, um médium, querendo-o ou não, sabendo-o ou não. Todavia, os espíritas distinguem entre o medianeiro, o médium nesse sentido amplo, e o médium ostensivo, aquele capaz de colocar-se explicitamente a serviço do Mundo Invisível. Tratase, no primeiro caso, da comunicação espiritual, comunicação imperceptível, difusa, cotidiana, que os Espíritos travam com os homens por meio do pensamento. E, no segundo caso, da comunicação espírita propriamente dita. A comunicação espírita pode assumir diversas formas. ${ }^{16}$ Todo aquele que a empreende é um médium no sentido estrito. Do ponto de vista dos freqüentadores, todos os espíritas são médiuns, i.e., são capazes de se desincumbir dos componentes rituais que relacionam explicitamente o plano terreno com o plano espiritual. Todo espírita sabe dar um passe e orar, por exemplo. Internamente, porém, do ponto de vista dos cooperadores, os espíritas tendem a reservar o termo médium para aquele que recebe Espíritos. É em oposição a este que se configura o "não-medium". $\mathrm{Na}$ verdade, estão em jogo diferentes graus do desenvolvimento da mediunidade (ver o capítulo IV). Embora todo cooperador adulto, com algum tempo de casa, tenha potencialmente acesso a todas as sessões, e esteja sempre incumbido de tarefas múltiplas e complementares, o não médium dedica-se preferencialmente às atividades relacionadas ao estudo e à caridade. Os médiuns acrescentam a elas a recepção de Espíritos.

\footnotetext{
${ }^{14}$ No ano de 1981, vários jovens do ano anterior haviam deixado as reuniões da juventude e iniciado o desenvolvimento de sua mediunidade.

${ }^{15}$ Os demais centros que freqüentei não o eram. No Lar de Tereza esse fato pode ser atribuído, ao menos em parte, a peculiaridade de sua origem, a casa de sua presidente.

${ }^{16}$ Ver o capítulo IV.
} 
Os médiuns em desenvolvimento são médiuns iniciantes cuja mediunidade deve ser observada e trabalhada. A eles destinam-se as sessões de iniciação espírita, desenvolvimento mediúnico e irradiação. Os médiuns desenvolvidos são os mais qualificados e os únicos capacitados para o exercício de algumas funções em alguns rituais e para a sessão de Desobsessão.

Embora as posições consideradas como de maior responsabilidade no centro sejam a princípio acessíveis aos cooperadores adultos, apenas os que estão em seu pólo mais interno, ou seja, os médiuns desenvolvidos têm acesso aos postos mais elevados. No Lar de Tereza, a presidente e a diretora administrativa, sua amiga pessoal e quem a substitui nas ausências e divide com ela a tarefa de direção do desenvolvimento mediúnico, são também os dois médiuns mais qualificados do centro. A autoridade que exerce no plano terreno deriva do contato com o plano espiritual, é conferida por ele. A mediunidade emerge como o valor englobante de todo esse sistema.

\section{O Sistema Ritual Espírita}

\subsection{A Mediunidade, o Estudo e a Caridade}

Como indiquei no capítulo II, a relação de complementaridade entre Mundo Visível e o Mundo Invisível segue dois eixos. O primeiro, diacrônico, organiza-se a partir da noção da reencarnação, remetendo às sucessivas passagens de um Espírito de um mundo a outro. $\mathrm{O}$ segundo, sincrônico, baseia-se na noção da comunicação espiritual, na permanente relação que existe entre Espíritos encarnados (Mundo Visível) e Espíritos desencarnados (Mundo Invisível). O sistema ritual espírita repousa sobre segundo eixo e tem na mediunidade a categoria cosmológica central de sua estruturação.

Mediunidade, porém, é uma categoria com vários níveis de inclusão. No seu primeiro e mais abrangente sentido, mediunidade é sinônimo comunicação espiritual, focalizando a relação sincrônica e permanente entre o Mundo Visível e o Mundo Invisível. A mediunidade é

acima de tudo uma ponte, um canal entre um recurso do Alto e o necessitado.

Todavia, os espíritas distinguem, dessa acepção mais global, um sentido específico, ou um "aspecto parcial" da mediunidade: a comunicação espírita na qual, através do personagem do médium, o Mundo Invisível e o Mundo Visível relacionam-se explicitamente. E, dentro desse sentido específico, medi unidade pode referir-se a uma das formas da comunicação espírita, a recepção de Espíritos. Essa multiplicidade de níveis da categoria mediunidade está presente no sistema ritual espírita. 
As organizadoras do Lar de Tereza classificam seus serviços e atividades em dois grupos básicos:

1. Atividades de estudo e prática espírita;

2. Atividades assistenciais.

O primeiro grupo compõe-se de:

a) Reunião pública;

b) Iniciação à doutrina espírita;

c) Atendimento fraterno;

d) Reuniões de juventude;

e) Reuniões privativas.

Estas últimas se subdividem em:

e.1. Passes de tratamento aos entrevistados;

e.2. Desenvolvimento mediúnico;

e.3. Sessão de irradiação;

e.4. Desobsessão.

O segundo grupo compõe-se de:

a) Assistência a famílias carentes;

b) Obras assistenciais diversas;

c) Bazar de caridade;

d) Oficina de costura;

e) Austin, posto assistencial do centro, ${ }^{17}$

No discurso do dia-a-dia, entretanto, os espíritas distinguem essas atividades como de estudo, de caridade, e mediúnicas. Nessa designação, mediunidade aparece como sinônimo da recepção de Espíritos, de uma forma específica da comunicação espírita. No entanto, as tarefas de estudo e de caridade, tomando-se mediunidade em seu sentido amplo, são também mediúnicas:

Os Espíritos vêm nos dizer que a mediunidade não se desenvolve apenas na mesa mediúnica, recebendo mensagens de Espíritos. A mediunidade se desenvolve também no trabalho de

\footnotetext{
${ }^{17}$ Ver folheto do Lar de Tereza, 1980. Não cheguei a freqüentar desse conjunto, de maneira regular, o bazar de caridade e a oficina de costura.
} 
caridade e no estudo. Pelo estudo nossa mente se esclarece e no convívio com o sofrimento vamos despertando cada vez mais a nossa sensibilidade. Entendemos assim que mediunidade não é só receber Espíritos. E estarmos com a nossa sensibilidade de tal forma evoluída que onde quer que estejamos possamos ser, na hora da necessidade de nosso próximo, a ponte entre o recurso divino e a necessidade de nosso irmão (...).

O estudo e a caridade são, portanto, também tarefas mediúnicas no duplo sentido do termo: por um lado, através delas estabelece-se o contato entre o Mundo Visível e Invisível, e nelas o espírita é sempre um médium no sentido amplo; por outro lado, o estudo e a caridade são componentes, tão relevantes como a experiência do transe, do desenvolvimento da mediunidade em sua acepção mais estrita. Um médium desenvolvido obrigatoriamente pratica a caridade e estuda regularmente.

Mediunidade refere-se assim a esse permanente contato que se exerce de diferentes modos, indo da maior intensidade de relação Espírito encarnado/Espírito desencarnado à menor intensidade dessa relação. $\mathrm{O}$ estudo a caridade e a mediunidade em seu sentido estrito são modalidades distintas de relação com o Plano Espiritual. De seu equilíbrio depende, em última análise, a identidade religiosa dos grupos em questão. No estudo e na caridade, a relação entre o Mundo Visível e o Mundo Invisível é mediada respectivamente pelo conhecimento e pelo amor humanos. A presença do Mundo Invisível, embora decisiva, permanece implícita. Na mediunidade, a relação entre os dois mundos é também mediada por uma instância humana representada no personagem do médium. Essa relação, porém, é aí mais intensa e direta, pois pela mediunidade o Mundo Invisível se torna visível, sua presença oculta se revela. Todo ritual espírita combina em certa medida esses diferentes modos de contato, que se sobrepõem, e cujo significado específico é sempre relativo aos demais, apresentando variações conforme o conjunto do ritual em questão. É a ênfase em um deles, contudo, o que permite aos espíritas distinguirem suas atividades como de estudo, de caridade ou mediúnicas.

$\mathrm{Na}$ terminologia weberiana, o estudo, a caridade e a mediunidade são, os principais meios de salvação no Espiritismo. Deles depende a obtenção de mérito e conseqüentemente a evolução espiritual do homem. No restante deste capítulo discuto a caridade e o estudo. Em razão de sua riqueza e complexidade a mediunidade será examinada no capítulo Seguinte.

\subsection{A Caridade}

O Espiritismo não diz que tudo está perdido, diz que fora da caridade há Salvação. (Allan Kardec) 
Cada homem, ser individual, e a humanidade em geral têm no Espiritismo uma natureza dupla: são corpo e alma, matéria e espírito. Todos os homens são assim "irmãos em Deus", seres da mesma natureza, partes do mesmo todo. Eles diferenciam-se, contudo, ao longo das sucessivas encarnações regidas pela evolução. A evolução é a de uma individualidade cósmica, o Espírito, que caminha no sentido do progresso, de um ponto zero de materialidade e inferioridade a um ponto infinito mais relativo de espiritualidade e superioridade. Se a trajetória evolutiva é assim em um plano individual ela é necessariamente referida ao outro. Um dos requisitos fundamentais para que ele se dê é o "amor ao próximo": "O progresso e o progresso junto ao outro." O destino de cada homem e da espécie humana estão imbricados.

é o amor sem esperar recompensa. Temos a certeza de que a destinação da Terra é para o progresso, para a evolução, Nascemos em determinada posição para ajudar o progresso do planeta. Se você parar sai da Lei da Vida. A evolução nunca será individual, ela é junto com o outro. E acreditar no papel do homem no mundo.

Nessa relação entre o eu e o outro terreno a caridade ocupa um lugar central. ${ }^{18}$ Toda tarefa espírita é em sentido amplo caridade, pois é um serviço de amor ao próximo. Receber Espíritos sofredores na reunião de desobsessão é caridade, dar um passe num freqüentador é caridade. Contudo, as tarefas designadas como de caridade são as obras assistenciais em

geral e com menos freqüência o atendimento fraterno.

$\mathrm{O}$ atendimento fraterno compõe com duas outras sessões - a reunião pública e a reunião de tratamento - um conjunto interligado. Quem chega ao Lar de Tereza pode marcar, se o desejar, uma entrevista com os cooperadares do centro. Essa entrevista é o núcleo do atendimento fraterno, que se realiza semanalmente em dois horários e se inicia como toda sessão espírita com a preparação do ambiente: leitura e comentário de texto evangélico e uma prece. As entrevistas são individuais, nelas relatam-se as mais diversas ordens de problemas: saúde, separações, mortes, filhos, emprego etc. Os cooperadores escutam com solicitude. Não se trata, porém, de uma consulta, como na Umbanda. Os cooperadores não estão mediunizados, i.e, não incorporam espíritos, e não devem em hipótese alguma dar conselhos que tirem a possibilidade de exercício de livre-arbítrio da pessoa. Não se deve afirmar nada sobre seu futuro, mesmo que alguma intuição se faça presente, ou que o cooperador tenha alguma visão (ver o capítulo IV). Os conselhos são assim de ordem geral, indica-se sobretudo a postura moral a ser adotada - coragem, paciência, fé etc. e prescreve-se um tratamento - frequiência às reuniões públicas e, em

\footnotetext{
${ }^{18}$ Para Uma discussão da caridade na Umbanda, ver Birman, 1980.
} 
casos considerados mais sérios, às reuniões de tratamento, e um ciclo de passes dados num aposento à parte após a própria entrevista. Esse tratamento é anotado na ficha de controle de que cada um dispõe e que deve ser apresentada em suas idas ao centro. Nela anota-se a data da entrevista seguinte, quando Interessado recebe "alta ou prosseguimento do tratamento".

Durante o ano de 1980, incluíam-se nas "obras assistenciais" as seguintes atividades: visitas semanais a um orfanato, a um asilo de velhos Se, hospital Miguel Couto, a manutenção de um posto assistencial em Austin ao e a assistência a famílias carentes, Considerarei para fins da análise basicamente a assistência a famílias carentes realizada em Austin e no centro.

No centro a assistência a faml1ias carentes Ocorre semanalmente no "dia das assistidas", como é chamado. As assistidas são mulheres não-espíritas, moradoras de favelas ou áreas pobres, que recebem ajuda regular do centro. São ao todo 83 famílias subdivididas em dois grupos que se revezam quinzenalmente. As mulheres "matriculamse" no centro, adquirindo uma ficha de controle onde se anotam a presença e suas dificuldades e problemas. Antes da matrícula definitiva há "um processo de triagem para Ver se gostam e vêm com freqüência". No posto de Austin são atendidas Segundo o mesmo modelo 50 famílias. Tanto em Austin como no centro o atendimento consiste na leitura e comentário de tema evangélico, prece, estudo da doutrina, prece e passes individuais, ingestão de água fluidificada, distribuição de mantimentos, consultas com médicos disponíveis e/ou entrevista com os cooperadores e um lanche ou almoço. ${ }^{19}$ Realizam.se paralelamente a evangelização e a recreação infantil.

Pode-se identificar como componentes rituais específicos dessas sessões a entrevista, no caso do atendimento fraterno, e a entrevista, serviços e distribuição de mantimentos, no caso da assistência às famílias carentes.A presença desses componentes é função de público a que se destinam. É sobretudo esse público o que define essas sessões como sendo do âmbito da caridade.

É o fato de se tratarem - freqüentadores, não-pobres, de um lado, e nãofreqüentadores, pobres, de outro - de pessoas por definição carentes, em busca, num caso, de conselho, de ajuda para problemas diversos e, no outro, também de ajuda material, o que aproxima ambos os públicos. Enfatiza-se nessas reuniões a doação de amor e compreensão humanos. Os pobres, porém, como símbolo privilegiado de uma humanidade carente e enfraquecida, ocupam um lugar especial. Caridade refere-se assim

\footnotetext{
${ }^{19}$ Em Austin essa seqüência é precedida por uma aula de crochê.
} 
preferencialmente à relação espíritas-pobres, a uma relação de reciprocidade entre desiguais não só no plano moral como social. De um lado, estão os espíritas que "dão", "esquecem-se de seu eu", dedicando-se ao Bem, e ao fazê-la ajudam não só o outro como a si próprios, "ganham pontos" para outra encarnação. De outro lado, os pobres que "recebem" não só a ajuda concreta como a oportunidade de tomar aquela existência de provações o início de sua redenção.

Como toda religião, o plano moral e o plano social estão no Espiritismo a princípio distintos. A hierarquia social de riqueza e poder e a hierarquia dos valores morais e espirituais são diferenciadas. Reside nesse ponto o potencial de inversões que dá às religiões em geral, e ao Espiritismo no caso um elevado poder de compensação. Mas, se há espaço para inversões, há contrapartida, uma forte tendência nessa religião no sentido do estabelecimento de uma relação de duplicação e reforço da hierarquia social.

No evolucionismo que vigorou na Antropologia de fins do século XIX, postulado da unidade básica do gênero humano permitia reduzir as diferenças históricas e culturais encontradas entre os povos a diferentes momentos de uma mesma história, a do homem, com um único sentido, o do progresso. ${ }^{20} \mathrm{O}$ evolucionismo Espírita forja, ele também, um dispositivo capaz de dar conta das mais diversas ordens de diferenças reduzindo-as a diferentes momentos da trajetória espiritual. O modelo pelo qual os espíritas pensam as relações entre Espíritos superiores e inferiores é o das relações terrenas: opõem-se governantes a governados, habitantes de centro a habitantes do subúrbio, patrão a empregado, colonizador a colonizado.

Se todos os Espíritos que habitam a Terra são, com raras exceções, Espíritos em evolução, pois a Terra é um "planeta de provações", o pobre é o símbolo vivo desse fato. É, mais do que ninguém, identificado à materialidade, à imperfeição. Num outro plano, porém, ele é um igual, é também Espírito e encontra-se também na Terra. A caridade inscreve-se nesse cruzamento entre a postulação de uma desigualdade tanto no plano social como moral e o reconhecimento de uma igualdade essencial.

Segundo a concepção de caridade espírita, deve-se dar não só a ajuda material de doação de bens e no sentido de dotar aquelas pessoas de meios para a obtenção de recursos próprios como ajuda moral. Daí a prática da caridade abranger não só a distribuição de mantimentos, como por vezes aulas de costura e crochê, e o estudo da doutrina. Seu circuito estabelece-se via mulheres; dedicam-se a ela sobretudo mulheres espíritas e são as mulheres pobres que a recebem. É um trabalho estritamente pessoal, não se trata de

\footnotetext{
${ }^{20}$ Ver, por exemplo, Tylor, 1970.
} 
alterar as estruturas, nosso trabalho é com as pessoas, é um trabalho de reforma do ser humano, é um trabalho junto ao sofredor, é ir no meio da lama, um trabalho que não tem quem faça.

$\mathrm{Na}$ caridade afirma-se contudo a diferença social e moral que distingue os espíritas dos pobres.

Como lembra Simmel,

(...) o fato de tirar dos ricos para dar aos pobres não se propõe igualar as suas respectivas situações, nem sequer em sua tendência se orienta no sentido da supressão da diferença social entre os ricos e os pobres. Ao contrário, a assistência se baseia na estrutura atual da sociedade. (...) O que ela se propõe é, justamente mitigar certas manifestações extremas da diferença social de modo que a estrutura possa seguir repousando sobre essa diferença ( $\mathrm{Sim}$ mel, 1917:485).

De um ponto de vista externo, a caridade é certamente uma prática conservadora no sentido em que Simmel o assinala. Nos termos do próprio sistema de crenças, contudo, essa visão não faz sentido. Não só a sociedade terrena é parte de uma sociedade maior, como o tempo terreno é parte de um tempo maior:

A eternidade está aí para isso mesmo. A seara não é nossa, é de Cristo. Se o semeador quiser apressar a colheita, acaba estragando tudo.

Desse modo, os espíritas "jogam sementinhas", semeiam o Bem que será colhido em outras encarnações.

Esse trabalho de reforma moral é direcionado pelos princípios espíritas cuja apreensão se faz ainda mais necessária entre os pobres para que "aprendam a lidar com suas dificuldades", para que entendam que sua condição não é em última análise injusta, mas sim provação e, como tal, merecida, correspondendo aos desígnios divinos, e à possibilidade de outra vida melhor. A doutrinação é simples

quando falo a elas, falo como a crianças. Tem que ser, qualquer coisa mais elaborada elas bloqueiam e não conseguem pensar em mais nada.

Os pobres são assim pensados como Espíritos inferiores, quando mais não seja por uma questão de "misericórdia divina", pois

Deus coloca nessa situação Espíritos que têm como que uma casca grossa. que os protege do sofrimento. Eles não têm sentimentos elaborados, conseguem suportar o que não suportaríamos.

$\mathrm{Na}$ tentativa de mitigá-la, afirma-se a desigualdade que é nesse sistema a possibilidade de uma igualdade futura essencialmente justa. 
Esse aspecto da caridade evidenciou-se para mim por ocasião de uma visita que fiz com um grupo espírita a um orfanato. Tratava-se de uma tarefa dos jovens, alguns dos quais estavam acompanhados de seus pais, também espíritas. O orfanato era extremamente pobre e sujo. As crianças, cerca de 200, de seis a 16 anos, eram na sua maioria negras, magras e pequenas. Estavam bastante sujas e mal vestidas. ${ }^{21} \mathrm{~A}$ tarde era de evangelização. Os jovens cantavam com elas músicas espíritas que tinham a função de preces. Contavam pequenas histórias de fundo moral. Faziam com elas uma recreação e ofereciam-lhes um lanche.

Terminadas essas atividades, enquanto alguns jovens se despediam das crianças, outros com alguns adultos sentaram-se num pátio descansando conversando. Um deles, Pedro, negro, morador de Bangu e cujo pai era chofer de caminhão, aproximou-se de um inspetor de orfanato, José, que havia torcido o pé numa partida de futebol jogada na recreação. Havia nesse trabalho uma orientação da dirigente de que os jovens buscassem uma aproximação com os inspetores, em função de denúncias de maus-tratos lá. Era preciso tentar transformá-los moralmente. Inspetores e crianças igualavam-se no sentido em que eram ambos vistos como sofredores e carentes, necessitados de auxílio. Pedro começou a massagear o pé de José, dizendo que seu sonho era dirigir um Scania, que devia ser gostosíssimo. José empolgou-se e entabulou com ele uma conversa. Pedro falava brincalhão de como o pai enganava a mãe, dizendo que estava doente da perna para ir ao baile e dançar a noite toda: "Conheço essas manhas! (...)" As demais pessoas em volta escutavam, desaprovando o tom da conversa. Criara-se uma situação de igualdade e identificação entre o jovem espírita e o inspetor pobre. Pedra retirou-se para despedir-se das crianças também. Um dos adultos perguntou então a José pelo seu pé, relembrando sua qualidade de inspetor. Como no ritual de separação de posições sociais do "Você sabe com quem está falando?" analisado por Da Matta (Da Matta, 1979), José voltou imediatamente a seu "devido lugar", o de inspetor do orfanato que machucara o pé.

Esse caso explicita o caráter hierárquico, demarcado $\mathrm{r}$ de lugares diferenciados, que caracteriza esse sistema como um todo, e toma-se particularmente claro na caridade. A separação das posições se impõe através do ethos espírita de discrição, seriedade, controle, solicitude e paciência para com os outros. Pedro era o contrário, expansão, brincadeira, não-controle. Em um sentido, seu comportamento igualava.o aos pobres. Tomava-o também inferior, tirava da caridade seu sentido.

\footnotetext{
${ }^{21}$ Pouco tempo depois a Funabem fechou esse orfanato por não ter ele condições básicas de manutenção. O bem mais precioso era para as crianças um saco de papel, que procuravam avidamente para depositar seus pertences: uma bola de trapos, agulhas feitas de canudos e palitinhos, meias velhas, transformadas em novelos de linha, pães e bolo do lanche para as horas de fome.
} 
Mas, se o Mundo Visível pode duplicar o Mundo Invisível, a grande distinção entre eles é o fato de que no Mundo Invisível a desigualdade baseia-se exclusivamente no moral. Afinal: "Herodes era rei e Jesus carpinteiro." Há assim espaço para inversões, como o caso de uma das assistidas acompanhada pela presidente de centro há 25 anos. Sua família era paupérrima, foi vítima das enchentes em 1966. O marido era tuberculoso e ela

uma criatura por quem tenho amizade imensa e de cuja boca nunca ouvi uma reclamação.

A identificação aí, ao inverso do caso acima relatado, repousava no fato de que aquela mulher era vista como

um Espírito superior que desceu num grupo de provação incrível para sustentá-lo.,

Se, de um lado, a caridade distingue e hierarquiza, de outro, ela aproxima e identifica. Funda-se não somente no reconhecimento da inferioridade alheia como no reconhecimento da própria inferioridade, da vontade e necessidade de redenção e evolução daquele que dá. Os espíritas são como "os rotos e os esfarrapados" de que Cristo falou. Como me disse a diretora de um dos departamentos,

é a pessoa doente que colocamos junto ao doente para se curar.

A caridade é uma cura de si mesmo através do outro.

Numa reunião das assistidas no Lar de Tereza,um senhor de meia. idade, advogado, que "faz do que precisa" - dá injeção, faz curativos, conversa com as assistidas -, sentou-se ao final ao meu lado, e contou-me a seguinte história:

Todo Natal, um homem se vestia de Papai Noel e levava presentes a dois orfanatos. Um ano abriu por perto um terceiro orfanato onde havia muitos paraplégicos, Quando ele estava distribuindo os presentes veio um paraplégico carregando outro no colo. O Papai Noel disse: "Não carregue ele não, meu filho! Ele é muito pesado." O menino respondeu: "Ele não é pesado não, Ele é meu irmão!"

Carlos terminou de contar a história com lágrimas nos olhos.

No Espiritismo, as doenças que implicam um defeito físico são geralmente vistas como cármicas, produto de más ações e simultaneamente punição e redenção de crimes e maldades cometidos em vidas pretéritas, O paraplégico ostenta em seu corpo seu mau passado, é um símbolo vivo do carma, da reencarnação. É "um Espírito sofredor e necessitado". Todos os homens redimem também nessa vida seu passado, e são também, em grau menor, sofredores e necessitados. A relação que se trava entre colaboradores espíritas e os pobres era representada na história por uma dupla analogia com a relação 
entre Papai Noel/paraplégicos, e paraplégico que pode carregar o irmão/paraplégico que precisa ser carregado. Num plano enfatiza-se a diferença: em outro a semelhança.

A caridade situa-se nesse cruzamento da afirmação de uma igualdade essencial e do reconhecimento de uma desigualdade moral que se sobrepõe por vezes a uma desigualdade social. Partindo do fato de que os homens são Espíritos encarnados, em evolução, e portanto imperfeitos, a caridade permite distinguir e hierarquizar, de maneira dinâmica e contextual,Espíritos (homens) mais ou menos imperfeitos.

\subsection{O Estudo}

Sua força está no seu bom senso, no apelo que faz à razão. (Allan Kardec)

A valorização do ideal da razão é explícita nas obras da codificação. Se,como vimos, nelas a verdade é em última análise revelada, no sentido em que foi transmitida pelos Espíritos, o procedimento pelo qual essa revelação se deu é visto como eminentemente racional. Ele exigiu que Kardec estivesse à altura dessa tarefa: os Espíritos respondem a perguntas formuladas por ele. Muito dessa verdade permaneceu ainda oculta aos homens, pois a revelação segue o estágio evolutivo da humanidade.

Demarca-se assim uma região conhecida e uma região desconhecida. Como diz Kardec:

Nenhuma ciência existe que haja saído prontinha do cérebro de um homem. Todas, sem exceção alguma, são fruto de observações sucessivas, apoiadas em observações precedentes, como em um ponto conhecido para chegar ao desconhecido. Foi assim que os Espíritos procederam com relação ao Espiritismo.Daí o gradativo ensino que ministram, Eles não enfrentam as questões, senão à medida que os princípios sobre que hajam de apoiar-se estejam suficientemente elaborados e amadurecida bastante a opinião para os assimilar. ( $A$ Gênese)

O Espiritismo tem assim uma visão do conhecimento semelhante à da ciência; o conhecimento caminha progressivamente, apenas aqui esse progresso é função da relação complementar entre homens e Espíritos. Há no conhecimento uma dimensão divina, pois ele é revelado, e uma dimensão humana, pois para que a revelação se dê, e novas revelações ocorram, é preciso que os homens estejam à sua altura, que também conheçam. Estes dois fatores: o espaço propriamente humano nessa verdade que se detém, e o seu caráter incompleto, definem uma outra dimensão da vida religiosa espírita: o estudo.

O estudo circunscreve um conjunto de práticas que consiste na lei aura,comentários, exposição de textos espíritas, na produção de artigos,apostilas e livros, na realização de debates, palestras, mesas-redondas. Expressa claramente a importância 
concedida à palavra oral e escrita que se revela também na própria existência de uma doutrina, e na constância respeito com que os espíritas se referem a ela. No grupo pesquisado, o es. tudo remete a dois contextos algo distintos entre si.

O primeiro contexto é o de cotidiano do centro espírita, onde o estudo está plenamente integrado às demais atividades espíritas. No lar de Tereza, a valorização do estudo liga-se ao entendimento e vivência do Espiritismo que lá se promove. Numa reunião pública a que assisti, o expositor referia-se a dois caminhos do Espiritismo:

o da mediunidade no qual muita gente fica, contentando.se com o fenômeno e o do estudo regular, que é o que aqui se faz.

Pois o estudo, segundo os espíritas, esclarece, transforma, leva as pessoas a "compreenderem as razões de sua dor". Só por meio do estudo, que "disciplina os sentimentos" e "nos ensina até mesmo a orientar nossas afeições", é possível alcançar a renovação íntima que é o caminho da evolução espio ritual. Pois o

Espiritismo não faz milagres, o milagre é fruto da atuação da pessoa.

Tem-se no Lar de Tereza extremo cuidado em "não viciar" o público na parte fenomênica (mediúnica) da doutrina com a qual se relacionam o passe e a água fluidificada. Nas reuniões das assistidas, nas reuniões públicas e de tratamento, o passe e a água fluidificada aparecem combinados ao estudo. O controle do acesso às sessões é feito em nome desse cuidado. No atendimento fraterno as entrevistas têm também esse intuito. Para que eu pudesse assistir às reuniões medi únicas, era preciso que eu "tivesse algum estudo", que fosse capaz de "compreender o que se passava". O estudo é uma prática que conduz à interiorização da doutrina, à "sua transformação em vivência evangélica", pois

a doutrina espírita deve ser como uma bagagem que trazemos sempre conosco para pensar e usar.

O estudo é assim um componente essencial do ser espírita, presente desde o primeiro contato com o centro, e extremamente importante, como veremos no capítulo seguinte, para o desenvolvimento da mediunidade. É estimulado tanto no plano individual como no plano coletivo. Em casa deve-se estudar sempre, ler todo dia nem que seja uma página de alguma obra espírita. No centro, o estudo refere-se ao aprendizado do conjunto de dou, trina, e reveste-se de ênfases diversas, dependendo do público a que se destine. As sessões designadas como de estudo são a reunião pública, a reunião de tratamento, a reunião da juventude e a iniciação espírita. As duas primeiras destinam-se aos freqüentadores. Nesse caso, a ênfase do estudo recai sobre o caráter moral, de consolação do Espiritismo, no 
aprendizado do bem-sofrer, como dizem eles. As duas últimas sessões visam os cooperadores respectivamente os jovens e os médiuns iniciantes. Nesse caso, o estudo ganha um caráter mais especializado, tendo como objetivo expresso o conhecimento da doutrina.

Entretanto, em todo ritual espírita o estudo está presente de uma ou outra maneira. Ele aparece de maneira branda na fase inicial de toda sessão, a preparação do ambiente. Essa fase do ritual pode ser pensada a partir da terminologia proposta por Van Gennep (Van Gennep, 1969; ver também Gluckman, 1962), como de separação. Nela é lido e comentado um texto evangélico, geralmente extraído dos livros do Espírito Emmanuel, Caminho, Verdade e Vida, ou Fonte Viva, psicografados pelo médium Chico Xavier. O texto é rapidamente lido e comentado por algum cooperador da casa (nas reuniões da juventude por um jovem). Todo espírita deve ser capaz de ler e comentar um trecho de um livro espírita diante do público ou de seus pares. O comentário e leitura na preparação do ambiente funcionam para os cooperadores como uma espécie de aprendizado e treinamento dessa técnica, que prepara o cooperador iniciante para a leitura e comentários mais demorados. Segue-se uma prece feita na penumbra, na qual se evocam os Espíritos protetores e amigos da casa. A preparação do ambiente tem por objetivo

desligar o pensamento das preocupações do cotidiano, para que seja possívelo bom aproveitamento da sessão, das vibrações, energias e presença dos guiasespirituais, preparar-se para entrar em comunhão com o plano espiritual.

Nela os espíritas mostram recolhimento e concentração caracterizados por uma postura típica: quem não está falando permanece sentado, a cabeça levemente inclinada apoiada nas mãos, os olhos cerrados. Toda tarefa espírita, realize-se ou não no centro, é precedida por esses procedimentos.

Além desse momento, o estudo está presente também, como já vimos, na assistência a famílias carentes, e reaparece modificado na última fase das reuniões mediúnicas quando, já acesas as luzes, examinam-se e estudam-se as mensagens recebidas, as visões tidas, o comportamento e as dúvidas dos médiuns. Nas reuniões designadas como de estudo, este situam-se na fase intermediária do ritual, a qual, intercalada pela prece e pela penumbra, apresenta de uma perspectiva temporal a maior duração (cerca de 30 a 40 minutos). Tomo como modelo para a breve descrição que segue as reuniões públicas e de tratamento.

Toda sessão espírita tem um dirigente. Nas reuniões em questão o dirigente é encarregado do comando da passagem entre os diferentes momentos rituais, e da 
formulação das preces. Além desse personagem emerge nessas reuniões como central a figura do expositor. Dirigente e expositor sentam-se numa pequena mesa em frente do público. Sobre a mesa ficam um microfone e os livros de referência. Atrás e um pouco à esquerda há um quadro-negro. Acesas as luzes, após a prece que conclui a preparação do ambiente, inicia-se o estudo. $\mathrm{O}$ expositor lê um trecho previamente selecionado de alguma obra da codificação (geralmente $L E, L M, E S E$ ). Terminada a leitura, o texto é retomado verbalmente, explicitado com recurso ao quadro-negro. Os temas são inúmeros: o sonho, as mortes prematuras o bem e o mal-sofrer, a reencarnação etc. Cada expositor deve dar a ele uma contribuição pessoal. O comentário soa assim extremamente informal embora a maneira uniforme como ocorre evidencie um padrão e um aprendizado subjacentes. O bom expositor fala firme, clara e calmamente, pacientemente como se lidasse com crianças. Há lugar para o improviso, para algumas brincadeiras moderadas que permitem a participação da platéia na forma de risadas, para o relato de casos pessoais. São sempre citadas outras obras espíritas, fornecendo-se por vezes referências bibliográficas precisas. A platéia escuta com ares mais ou menos atentos. Algumas pessoas fazem anotações. Ao final, por vezes fazem-se perguntas. Qualquer pergunta que não seja estritamente doutrinária é contornada. Segue-se a fase final do ritual, geralmente composta do passe, prece e ingestão de água fluidificada destinada a "pacificar a mente e restaurar as energias", preparando as pessoas para o retorno ao profano, "para levar a mensagem de amor para seus lares".

O expositor é um pregador, ele transmite aos homens a Verdade dos espíritos. Essa transmissão está envolta pelo plano espiritual, é um momento do encadeamento ritual que contacta Mundo Visível e Mundo Invisível. O expositor em sua fala é assistido pelo mentor e por amigos espirituais do centro, e os médiuns presentes estão todo o tempo especialmente encarregados da manutenção de um bom ambiente, emitindo, através da prece íntima, da concentração, do pensamento no Bem e em Cristo, vibrações positivas. Essa proteção é indispensável, pois, segundo os espíritas, o expositor é

terrivelmente assediado e perseguido pelas trevas porque a palavra que ele traz para os encarnados repercute também no Plano Espiritual. São colocados alto falantes nas redondezas do centro, e até os Espíritos desocupados que passam escutam as suas palavras.

Essa transmissão, porém, é mediada pelo conhecimento humano. Essa instância humana que se evidencia no estudo complementa de modo indispensável a relação com o espiritual tal como os espíritas a valorizam. Ela figura um dos espaços de exercício do livre-arbítrio do Espírito. Como dizia uma expositora, 
espíritas nossas respostas, evitando fazer com que os Espíritos venham dar consulta, ${ }^{22}$

Há também um outro estudo que, à diferença desse, explora os pontos da doutrina que não foram plenamente revelados, os quais, tal como o apresentados na codificação, deixam em aberto inúmeras questões, ou então que explora sempre "à luz do Espiritismo" a relação entre essa religião e outras áreas do conhecimento como a Medicina, a Psicologia, o Direito etc. ou outras religiões. Emerge nesse espaço um personagem que chamei de o "intelectual espírita". O Instituto de Cultura Espírita é expressivo desse segundo sentido do estudo que, mesmo permanecendo subordinado ao conjunto desse sistema de crenças, ganha uma certa autonomia com relação às demais atividades espíritas.

Os objetivos do ICEB são "o estudo, difusão e defesa dos princípios espíritas". A instituição é oriunda da antiga Faculdade Brasileira de Estudos Psíquicos. ${ }^{23}$ Seu atual presidente e alguns de seus expositores eram professores da antiga faculdade. Quando não foi mais possível a sua existência, esse grupo e alguns novos elementos fundaram em 1957 o ICEB. Por problemas legais e fiscais, trocou-se a palavra professores por expositores. Essa origem marca o caráter do ICEB, que se vê como "uma instituição livre como livre sempre foram as cátedras", e vem ao encontro de uma de suas características centrais, a valorização não só do conhecimento doutrinário mas do conhecimento em geral; a preocupação permanente com a legitimação do Espiritismo como interlocutor digno das demais áreas de saber, sobretudo as chamadas ciências oficiais. Na duração do ciclo de palestra, a do ano letivo; na concepção do programa trienal no qual cada expositor é dono de uma matéria; na lista de presenças, que deve ser sempre assinada, evidencia-se a referência ao modelo escolar/universitário. Lá "estuda-se", muito embora "no Espiritismo não se receba certificado de conclusão".

A organização do espaço no ICEB é semelhante ao das reuniões doutrinárias no centro, em escala aumentada. O presidente da instituição e os expositores do dia sentam-se a uma mesa sobre o palco, dispondo também de um microfone e tendo à sua esquerda um quadro-negro. As paredes do salão são também azuis e comportam dois grandes relógios. O presidente inaugura a sessão com uma prece intima. Seguem-se as palestras. A fala dos expositores não tem um conteúdo moral tão explícito como no centro. O público é supostamente mais seleto, e os expositores podem falar com mais liberdade, "aprofundarse mais no assunto". A fala é, em parte, uma demonstração de conhecimento não só da

\footnotetext{
${ }^{22}$ Ver a esse respeito também o capítulo IV.

${ }^{23}$ Segundo o presidente do ICEB, havia no começo da República muitas escolas livres: "Isso por influência do Positivismo, que era contra o ensino universitário. Sua concepção de respeito pela liberdade individual chegava ao ponto de achar que o individuo devia estudar livremente. Algumas depois tornaram-se oficiais, algumas faculdades de Direito começaram assim."
} 
doutrina - abundam referências precisas a obras da codificação e de outros autores - como de "outras ciências" - são constantes as referências aos "pensadores materialistas" como Piaget (teoria do aprendizado), Vico (idéia de forças criadoras na História), Bergson (intuição), Freud (teoria da libido e do inconsciente), Mendell (hereditariedade) etc. ${ }^{24}$

O intelectual espírita é também um expositor. Distingue-se, porém, pelo fato de gozar de renome no seu meio, viajar freqüentemente para conferências, proferir palestras em vários centros, escrever artigos em jornais espíritas e publicar livros. Tem uma reflexão pessoal a oferecer sobre de. terminado assunto. Como todos os homens o intelectual espírita está sempre influenciado por Espíritos, e o grau em que essa influência se dá é aqui como em todo esse sistema por vezes difícil de determinar. Ouvi certa vez, por exemplo, uma referência a um espírita portador de "mediunidade oral": no momento em que sua palestra se iniciava "era como se rodasse em sua mente uma fita magnética"; sua fala era mediúnica, transmitida por Espíritos. Embora essa possibilidade esteja sempre presente, esses intelectuais são autores de vários livros não-mediúnicos. Na medida em que, tendose em conta a permanente influência espiritual, se assume a autoria pessoal dessas obras, das idéias expostas, essa produção ganha o caráter assumido de especulação, pesquisa, um caráter humano e provisório. Essa produção insere-se assim num espaço distinto do das obras mediúnicas. Sua autoridade é duplamente limitada: interessa a uma parcela apenas dos espíritas e é produto de homens, de Espíritos encarnados.

Além do caráter mundano, presente em toda religião, e que faz com que a frequiência ao ICEB se constitua no programa de sábado à tarde dos espíritas, que conversam animadamente no intervalo e no final, pode-se perceber aqui, de maneira apenas mais aguda do que no centro, a natureza de espaço propriamente intelectual que o Espiritismo apresenta, e que chamou a atenção de autores como Renshaw (Renshaw, 1969) e Camargo (Camargo, 1961). A valorização do estudo relaciona-se a características estruturais desse sistema de crenças. É preciso que os homens, de seu lado, estudem e conheçam, participem em sua dimensão humana e menor dessa Verdade que os Espíritos detêm e lhes transmitem gradualmente. O estudo eleva o homem, dá-lhe firmeza e segurança, torna-o digno dos Espíritos. Essa religião desenvolve assim em seus adeptos um gosto pelo conhecimento, pela leitura, uma sede de saber.

Embora o valor do estudo esteja claramente subordinado ao conjunto desse sistema, ele implica como vimos o reconhecimento de uma área de uma certa autonomia do

\footnotetext{
${ }^{24}$ Seria interessante pesquisar no que diz respeito à relação entre o Espiritismo e Ciências oficiais, com quais teorias e correntes os espíritas dialogam. Para além da já mencionada relação com o Evolucionismo, não tenho, contudo, material suficiente para explorar esse ponto.
} 
humano. Assim, visto como relevante, ele deve ser mantido sob estreito controle. Pareceme repousar sobre esse ponto as freqüentes advertências de que

é mais fácil recolher criaturas de maiores cabedais de amor com reduzida inteligência e convivermos com elas, no processo evolucionário comum, do que abrigarmos pessoas sumamente intelectuais sem amor aos semNo Mundo elhantes (...). (Maior; do espírito André Luiz, pelo médium Francisco Cândido Xavier)

as acusações de elitismo por vezes atribuída aos intelectuais; e as preocupações e constantes esforços destes em afirmar a importância e o valor da"seara alheia", o caráter complementar de suas atividades.

Ao mesmo tempo o estudo é um símbolo de status, uma resposta de que se dispõe para as acusações de misticismo e crendice que marcaram a história do desenvolvimento dessa religião no Brasil $^{25}$ e que ainda hoje se fazem presentes (ver Conclusões). Uma característica que comprova a sua seriedade, e que na visão dos espíritas demarca claramente sua diferença com relação às demais religiões mediúnicas. $\mathrm{O}$ estudo afirma a posição no mundo desse grupo social.

\section{ANEXO I}

Foram os seguintes os incidentes mencionados na p.50:

1) jovem $x$ dirigente jovem

Em uma das visitas que fiz com os jovens a um orfanato eles fizeram um grande círculo para orar antes de entrar. O jovem líder aproveitou a ocasião para dar uma série de informações. Uma delas dizia respeito a alterações que "nós decidimos com relação ao trabalho com as crianças". Um dos jovens presentes protestou imediatamente: "Nós é que não!" Criou-se um constrangimento momentâneo, que foi superado com a afirmação do líder de que a decisão fora tomada em reunião.

2) jovem x diretora do Departamento de Infância e Juventude

Por ocasião de uma ida dos jovens ao posto assistencial do centro, no subúrbio. O encontro para saída era no centro. Como alguns dos jovens estavam atrasados, a diretora resolveu ir na frente com os que estavam presentes. Um deles manifestou o desejo de ficar esperando os demais para falar com uma jovem. A diretora não lhe respondeu. Iniciou a preparação para a tarefa que iam realizar. Abriu uma página de um livro do médium Chico

\footnotetext{
${ }^{25}$ Ver a esse respeito Renshaw, 1969: 54-56 e Anais do ICEB, vol.III.
} 
Xavier, a qual foi lida e comentada. No comentário falou-se sobre a necessidade de dedicação ao Bem, do esquecimento dos desejos egoísticos e pequenos do Eu, em suma, da superioridade moral do dever, que é sobre tudo uma tarefa pela qual se opta.

3) médium em desenvolvimento $x$ dirigente da mesa mediúnica

Normalmente quem dirige a mesa mediúnica é a presidente do centro. Como esta não se achava presente, uma médium, assídua cooperadora, substituiu-a. Ao contrário da presidente, Marta, iniciado o período de tempo em que os médiuns dão passividade aos Espíritos, não parava de falar, fazendo preces e recomendações. Na primeira parte da sessão uma médium pôs as mãos nos ouvidos. Na parte dedicada à incorporação, manifestaram. se Espíritos bem mais violentos do que é comum nas sessões de desenvolvi. mento. Um deles dizia, através de um rapaz: "Eu vou tumultuar, eu vou tumultuar!" E passava as mãos por cima da mesa, desarrumando os papéis, contorcendo-se e gemendo. Outro, através de uma senhora, reclamava da bagunça. Marta encerrou essa parte da reunião bem mais cedo do que o normal. Espíritos jovens, sofredores, rebeldes e autoconfiantes, que haviam sido levados até lá pela mãe, foram responsabilizados pelo ambiente. Esse fato não excluiu uma severa repreensão aos médiuns, que, caso continuassem a se comportar daquele modo indisciplinado, não deveriam sentar-se à mesa mediúnica, pois estavam perigosamente dando passagem a Espíritos obsessores (ver o capítulo IV).

4) diretora do Departamento de Infância e Juventude x presidente do centro

Num dia de atendimento fraterno, eu aguardava para conversar com a presidente do centro. A sala estava já praticamente vazia. A presidente conversava com a diretora. Esta última estava ressentida e magoada porque aquela, que a substituíra um dia no posto assistencial, alterara a organização das atividades. A presidente argumentava pacientemente que fizera aquilo por motivos estritamente pessoais: ela, Betânia, sentia as coisas correrem melhor daquela maneira, o que, no seu entender, não significava que Yeda devesse fazer as coisas do mesmo modo. Yeda saiu ainda bastante aborrecida e Betânia manifestou alguns sinais de irritação. 
capítulo IV

A MEDIUNIDADE

(...) A sociedade do Além-Túmulo e a sociedade da Terra são uma e a mesma coisa, continuação uma da outra, em fases diferentes, apenas com a só dificuldade de ser a primeira invisivel e por vezes ignorada pela segunda.

(Yvone Pereira)

\section{Mediunidade, Transe e Possessão}

Religiões mediúnicas, religiões de possessão, ou religiões extáticas são classificações das religiões que focalizam a relação/tomada do corpo humano com/por uma força espiritual. Agrupam-se, desse modo, fenômenos culturalmente recorrentes, presentes em inúmeras sociedades tanto primitivas como modernas, bem como na própria tradição cultural ocidental. ${ }^{1}$ Define-se um campo rico para um trabalho comparativo. Para além desse ponto, contudo, as maneiras de classificar e pensar os fenômenos apontados divergem bastante.

Em um exame de parte da literatura sobre o tema, Hoskins (Hoskins, 1975) distingue três fenômenos diferentes contidos por vezes sob a mesma rubrica: a mediunidade, que designa genericamente $\mathrm{o}$ fato da comunicação entre homens e espíritos, não se confundindo com a possessão; o transe, que se refere a alterações orgânicas e fisiológicas no estado corporal tido como normal; e a possessão, definida geralmente como um estado de consciência "alterada", no qual o indivíduo experimenta no próprio corpo a manifestação dos seres em cuja existência acredita. Há assim transe sem Possessão e possessão sem transe, embora o mais freqüente seja a associação dos dois fenômenos.

A significação desses três termos, porém, nem sempre é a mesma, alterando-se de autor para autor. Roger Bastide distingue entre transe místico e possessão. O transe místico engloba casos como o xamanismo, que se caracteriza pelo fato de que o xamã não é possuído pelos espíritos que permanecem exteriores a ele (Bastide, 1972: 77). Já Luc de Heusch diferencia entre xamanismo - ascensão do homem aos deuses e adorcismo - e poso sessão - descida dos deuses ao homem e exorcismo (Luc de Heusch, 1973, 255) - como duas estruturas religiosas antinômicas. Segundo esse autor o xamanismo situa-se no plano da magia e a possessão implica a existência de um sistema religioso ou mágico-religioso, constituindo um ritual coletivo. Mary Douglas adota a distinção de Firth (Firth, 1967: 296)

\footnotetext{
${ }^{1}$ Ver a esse respeito os trabalhos de Weber, 1967; Dodds, 1951;Jean-Maire, 1970; Vernant, 1973, 1977 e Gernet, 1976.
} 
entre três tipos de estados de transe, que vão do máximo de controle dos homens sobre o espírito ao mínimo de controle. São eles: a possessão, estado no qual o homem perde passivamente controle para o espírito; a mediunidade estado no qual o espírito fala através da pessoa possuída e o grupo tenta obter do espírito informação e poder; e finalmente o xamanismo, estado no qual o espírito é domesticado e faz a vontade do anfitrião humano, A esses três tipos a autora acrescenta um quarto, no qual pode ocorrer que a pessoa humana perca consciência sem que isso implique uma visão do estado, como indesejável ou perigoso. É o "culto positivo do transe" (Douglas, 1970: 105).

Como se pode perceber, os princípios que orientam essas classificações são distintos, e o desacordo com relação à terminologia utilizada revela uma certa precariedade desse campo de estudos.

Discutindo a classificação recolhida, Hoskins aponta o caráter problemático da definição do transe e da possessão como estados alterados. ${ }^{2} \mathrm{Um}$ estado alterado requer a existência de um estado normal. O normal é, nessa visão, identificado ao natural na suposição equivocada de que exista um "normal" transcendente às diferentes culturas (Hoskins, 1975). Os demais autores citados consideram a possessão como uma conduta normal em determinadas sociedades, aberta a todos e regi da por padrões culturais. No caminho de Durkheim, a possessão é vista como um meio de acesso ao sagrado, trazendo a marca da cultura que a produz. Se as condutas não são "anormais", elas são contudo "estados de dissociação" corporal ou mental (Lewis, 1971: 41 e Douglas, 1970: 104). O significado do conceito de dissociação não é explicitado. Sem pretender desenvolver essa discussão nos limites deste trabalho, chamo atenção apenas para o fato de que esse conceito se apóia em determinadas concepções da psicologia e da patologia, não sendo, portanto, neutro.

Lévi-Strauss (Lévi-Strauss, 1978) discute a relação entre possessão e loucura e sugere duas possibilidades com relação às condutas descritas sob o nome de transe ou possessão: ou elas não têm nada a ver com aquelas são chamadas na nossa sociedade de psicopatológicas, ou podem ser que consideradas do mesmo tipo. Neste último caso, a conexão com estados patológicos deve ser vista como contingente, resultado de uma condição particular à sociedade em que vivemos (ibid., xviii). Essa segunda possibilidade, que refina a visão do fenômeno, não tem todavia sido explorada pelos estudiosos do assunto.

\footnotetext{
${ }^{2}$ para o exemplo da utilização dessa definição, ver Bourguignon, 1973.
} 
Lewis (Lewis, 1971) e Douglas (Douglas, 1970) elegem como problemática central a relação existente entre a sociedade e o transe. A questão de Lewis é relacionar o êxtase e a ordem social. Questão que se transforma e se resolve na formulação de uma tipologia da possessão e suas funções correia tas. Há, segundo o autor, dois tipos básicos de possessão. O primeiro tipo é a possessão periférica, característica das camadas oprimidas da sociedade, vista como

um auxílio aos interesses dos fracos e oprimidos sem outra forma de pressionar suas reivindicações por respeito e atenção (Lewis, op. cito : 33).

Ela

emerge em sua função social primária como uma estratégia agressiva oblíqua,refletindo tensões sociais (Lewis, op. cit.: 112).

O segundo tipo é a possessão central, que o autor qualifica como pertencendo aos homens poderosos. Elas existem nas religiões aceitas e absorvidas pela sociedade cujos espíritos cuidam de aspectos da moralidade pública e nas quais, diferentemente do primeiro tipo, há atribuição de culpa aos agentes envolvidos.

A questão de Mary Douglas é semelhante, embora formulada e desenvolvida de maneira mais complexa. A autora pretende relacionar idéias cosmológicas e características das relações sociais, ou, em outras palavras, "tipos de estruturas simbólicas e variáveis sociais previsíveis". Distinguem-se duas dimensões sociais nas quais os indivíduos interagem: o eixo da ordem, da classificação, do sistema simbólico (grid); e o eixo das pressões e de controle sociais (group) (Douglas, op. cit.: 80-97). Com base nesses dois eixos, especificam-se quatro tipos sociais que geram cosmologias distintas,configurando a hipótese de que o sistema de controle é validado por um bias típico no sistema de crenças. A hipótese de Bernstein de que o padrão as relações sociais marca as formas de comunicação verbal é ampliada para as formas de comunicação não-verbais, em especial o uso do corpo (Douglas, op cit.: 92). A autora distingue entre o corpo físico e o corpo social, este constrangendo a maneira pela qual aquele é percebido:

a experiência física do corpo, sempre modificada pelas categorias sociais pelas quais é conhecida, sustenta uma visão particular da sociedade. Há uma contínua troca de significados entre as duas formas de experiência corporal de 1110do que uma reforça as categorias da outra (...).

O controle do corpo no ritual é visto como uma expressão do controle social, e, paralelamente, o abandono desse controle responde também às exigências da experiência 
social. O fenômeno do transe é particularmente adequado para essa teoria. A ênfase na consciência e a visão do transe como algo perigoso correspondem a uma estrutura social que exige o Controle do comportamento individual. A inarticulação da organização social ganha expressão simbólica na dissociação corporal e,

como o transe é uma forma de dissociação, ele será tanto mais aprovado quanto mais fraca for a estruturação da sociedade (Douglas, op. cit.: 104).

Forja-se a partir daí uma tipologia do transe e das atitudes relativas a ele, que variam conforme a maior ou menor articulação social, maior ou menor controle do comportamento individual.

A argumentação é complexa, e algumas de suas formulações, como a distinção entre corpo físico e corpo social, são sugestivas. O transe, porém, é aí sobretudo expressão do controle e articulação sociais. Em toda a discussão, o social e o simbólico são pensados como exteriores um ao outro, mantendo uma relação especular que termina por reificar ambos. Em contrapartida, se adotarmos a visão da sociedade como sendo ela mesma um sistema simbólico (Lévi-Strauss, 1978), os conceitos de crença (e seus derivados como transe e possessão) tornam-se mais claramente conceitos, abstrações, que ajudam a pensar, uma vez que não se dispõe de outros, sobre uma mesma realidade. Um sistema simbólico não é um fato social porque expressa um social exterior a ele, ele é em si mesmo o que chamamos de social. Ele não revela uma experiência social particular, é uma experiência social particular que comporta diferentes planos e existe evidentemente em relação com diversas outras. Enquanto um sistema religioso, o Espiritismo produz uma determinada maneira de ser, de estar no mundo ${ }^{3}$ que é característica de segmentos das camadas médias. A variável sociológica de classe não é nesse sentido externa mas interna aos sistemas religiosos.

Certamente o Espiritismo fala de, e reflete sobre, a sociedade da qual participa. E algumas características desse sistema religioso podem ser relacionadas a valores sociais mais gerais. Sua concepção hierárquica e evolutiva do mundo coaduna-se com um modelo hierárquico de sociedade. A prática da caridade propõe uma visão conservadora da estrutura social. O elevado grau de controle do corpo, como veremos neste capítulo, e o acentuado respeito à pontualidade ligam-se a valores mais gerais do controle social.

Chamo atenção, contudo, para o fato de que a relação do domínio religioso com os

\footnotetext{
${ }^{3}$ Ver Geertz, 1978.
} 
demais domínios sociais não é monolítica, não se dá numa única direção. Além de haver no próprio Espiritismo margem para divergências (ver o capítulo I), existem certamente espíritas de diferentes posturas diante do mundo, conservadores, liberais ou comunistas, por exemplo. O Espiritismo é uma das matrizes disponíveis. A maneira pela qual as diferentes atrizes de leitura do social se combinam na experiência social total dos indivíduos, ou o que leva pessoas de segmentos das camadas médias a se tornarem espíritas são questões que extrapolam o âmbito desta pesquisa. Minha pergunta é qual a especificidade do ser espírita. E minha ênfase recai na apreensão dos valores, categorias e representações que constituem essa experiência religiosa.

Com base nessa discussão, este capítulo focaliza a categoria espírita mediunidade. Esta categoria constitui-se, como vimos no segundo eixo ordenador da relação entre Mundo Visível e Mundo Invisível, e, por conseguinte, no segundo eixo ordenador da construção da noção de pessoa no Espiritismo. Embora haja nessa religião uma reflexão sistemática sobre a mediunidade, uma preocupação explícita com seus mecanismos, cabe lembrar que a apresentação que se segue é o resultado de uma pressão ao qual esse tema não está ordinariamente submetido. Trata-se em suma mais uma vez de um modelo construído a partir das representações espíritas. A mediunidade é em si mesma um campo de estudo, de pesquisa. Muita coisa é considerada desconhecida, havendo espaço para discordância, debates, novas formulações. As explicações de um determinado fenômeno nem sempre são excludentes, sobrepõem-se uma à outra, sendo o contexto o que determina a ênfase numa ou noutra. Cada caso é sempre um caso cuja explicação particular deve ser procurada.

Evitei utilizar os conceitos de transe, possessão ou mediunidade tal como usados pela Antropologia como ponto de partida. A tentativa é a de apreender a particularidade das representações espíritas sobre os fenômenos em questão.

Utilizo ao final o termo transe como equivalente do termo espírita manifestação mediúnica. Com ele chamo atenção para um momento ritual claramente demarcado, para o qual convergem os diversos princípios que governam esse sistema de crenças e no qual a pessoa, como o Espiritismo a concebe, se atualiza e se afirma.

\section{A Mediunidade como Dom e Exercício}

Se mediunidade designa no seu sentido mais abrangente a constante relação que vigora entre Espíritos encarnados e desencarnados, sendo nesse caso sinônimo de comunicação 
espiritual, mediunidade refere-se também à possibilidade dessa comunicação por parte do Espírito encarnado. Nesse contexto ela é, segundo o Espiritismo, um dom orgânico, derivado da estrutura do corpo físico

Vimos acima que a pessoa é percebida nessa religião como um composto de três elementos: o espírito, o perípirito, e o corpo. Os Espíritos comunicam-se através do pensamento e da vontade. Pela força de seu pensamento e da sua vontade. Eles emitem vibrações que se imprimem sobre o fluido universal, principal veículo de contato entre Mundo Visível e Mundo Invisível. Nos Espíritos desencarnados, a relação pensamento/vibrações/fluido universal é direta. Nos Espíritos Encarnados essa relação passa pela inevitável mediação do corpo físico

No corpo físico há uma infinidade de plexos,

regiões do organismo humano onde existem entroncamentos nervosos, ou de veias e artérias que partem desse ponto para atender a regiões várias (Apostila sobre o Passe).

Dessa infinidade destacam-se sete plexos, que correspondem no perispírito aos chamados centros de forças. A localização dos plexos e centros de força é representada pelo seguinte desenho:

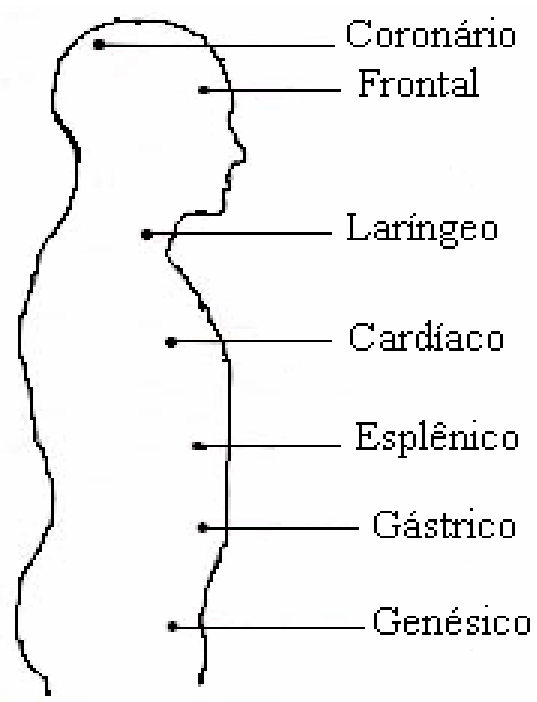

\section{Diagrama 5}

1. O centro coronário, localizado no cérebro, no alto da cabeça, nomeio da região em que se encontra a principal glândula do corpo humano a epífise ou glândula pineal, sede da vida mental, diretora da vida psíquica do homem. Como sede do pensamento e da vontade, essa glândula chama-se também glândula da mediunidade.

2. O centro frontal que corresponde no corpo físico à glândula hipófise ou pituitária. 
Esse centro é visto como o regulador da atividade intelectual.

3. O centro laríngeo. situado na garganta, tem como correspondente no corpo físico as glândulas tireóides e paratireóides. Esse centro controla todo o aparelho fonador e respiratório.

4. O centro cardíaco, na região onde se localiza no corpo físico o coração, é o centro responsável pelos sentimentos e emoções.

5. O centro esplênico, que corresponde à região do corpo físico onde se situa o baço, o plexo mesentérico, é o responsável pela filtragem das energias que circulam no perispírito.

6. O centro gástrico, que corresponde no corpo físico ao plexo solar, localiza-se no estômago. Assim como o plexo solar é responsável pelas funções da alimentação, o centro gástrico no perispírito seleciona a alimentação energética que o Espírito ingere: fluidos pesados, danosos, provocam imediata dor de cabeça, náusea, vômito, energia prejudicial que deve ser expelida.

7. Finalmente o centro genésico, que corresponde no corpo físico ao plexo sexual ou hipogástrico, responsável pela sexualidade, reprodução e criatividade em geral.

Todos os centros estão ligados por linhas de força pelas quais circulam energias fluídicas absorvidas pela respiração ou transnútidas por determinadas formas de comunicação espiritual. No Espírito Encarnado os centros de força são os pontos de ligação do espírito com o perispírito. O perispírito por sua vez, acopla-se no corpo na zona do tálamo, "zona da estrutura das funções", situada na base do cérebro. Circula no sangue e tem nos centros de força os pontos de ligação privilegiados com o corpo físico. Dependendo de seu grau de densidade, i. e., de sua maior ou menor materialidade, o que é produto da evolução espiritual, a inserção do perispírito nas células é, segundo os espíritas, maior ou menor. Quanto menor sua materialidade, quanto menor a sua inserção nas células, maior a mediunidade do Espírito encarnado, a sua capacidade de estabelecer e receber a comunicação espiritual.

A mediunidade é assim um dom orgânico. Todavia, as afirmações acima, que relacionam a maior ou menor materialidade do perispírito com maior ou menor medi unidade do Espírito encarnado, permitem perceber que não estão em jogo apenas concepções da ordem do físico, do material. A materialidade do perispírito (e portanto a maior ou menor mediunidade do espírito encarnado) é produto da evolução espiritual. A mediunidade surge como uma categoria limítrofe entre a ordem material e a ordem 
espiritual. Sua "base é orgânica, porém seu fundo seu fundo é absolutamente espiritual".

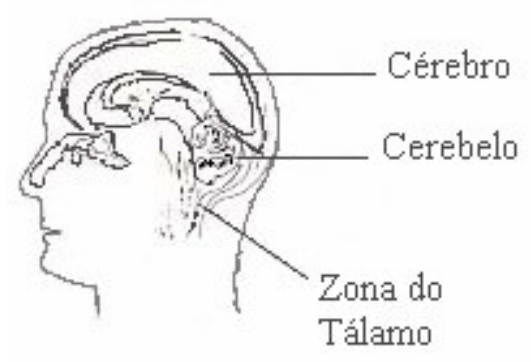

\section{Diagrama 6}

Essa formulação aponta duas visões complementares acerca do fenômeno. De um lado, a mediunidade é um dom, e como tal inato é espontâneo. Todos a detêm e todos são potencialmente médiuns. Em alguns casos, contudo, esse dom é excepcionalmente desenvolvido. Yvone Pereira, uma médium psicografa moradora do Rio de Janeiro, cuja mediunidade é considerada pelos espíritas como extremamente fidedigna, comparável em menor escala à Chico Xavier, afirma que

Existem mediunidades desde o berço, são as mais seguras porque as mais positivas, frutos de longas etapas encarnatórias (....). ${ }^{4}$

Mas, como essa citação permite perceber, se a mediunidade tem uma base orgânica, sendo nesse sentido inata, e se esse fator é importante, atuando como diferenciador na hierarquização da confiabilidade dos médiuns, esse dom só é excepcional porque já foi trabalhado em outras encarnações. Além de, como dom, a mediunidade ser si neutra, ter um valor zero, sua qualidade depende inteiramente da direção que a ela é imprimida, do sentido em que é canalizada, que pode ser o do Bem ou o do Mal. De outro lado, a mediunidade é também exercício, educação.

Vimos no capítulo II como por meio do parispírito "os frutos do trabalho de uma encarnação se encravam na alma". Como um aspecto do desenvolvimento espiritual geral de um espírito desencarnado, a mediunidade é parte da herança cósmica individual geral de um Espírito encarnado, a mediunidade é parte da herança cósmica individual. Como dom do trabalhado, ela pode acompanhar as diversas encarnações de um Espírito. Contudo, "em cada encarnação vêm ao consciente apenas os caracteres necessários para a missão escolhida (...)". Um médium nessa encarnação não foi necessariamente nas

\footnotetext{
${ }^{4}$ Pereira, in recordações da mediunidade, p.19
} 
anteriores, nem o será obrigatoriamente nas futuras. Tudo depende dos desígnios divinos, e da escolha de sua missão para a vida encarnada. ${ }^{5}$

Embora o grau de desenvolvimento da mediunidade possa ser diretamente relacionado ao grau de evolução espiritual, e o grau máximo de autoridade humana derive como veremos, da confiabilidade de determinado médium, evita-se relacionar explicitamente o desenvolvimento da mediunidade a superioridade do espírito em matéria de mediunidade de espírito. Como me dizia uma das médiuns do lar de Tereza nada se pode afirmar na verdade, a relação de desenvolvimento da mediunidade/superioridade do espírito é uma relação possível, mas não necessária. Em sua base, como dom orgânico, a mediunidade é como vimos, neutra. Depende portanto, em última análise, unicamente do Espírito encarnado comandá-la num ou noutro rumo. Nada impede de Espíritos inferiores tenha uma mediunidade tenham uma mediunidade poderosa, nada impede a princípio que um médio coloque sua mediunidade a serviço do mal. Ao mesmo tempo, a explicação dessa relação daria margem à vaidade, o esquecimento de que é simplesmente um instrumento a serviço do plano espiritual, é um dos grandes perigos que ameaça o médium. Eal pode fazer com que um médium caia, perca a cobertura Espiritual (ver adiante, p.92).

A mediunidade configura-se então como um bem extremamente poderoso e duplamente perigoso. Perigoso não porque, enquanto neutro, pode ser posto a serviço do bem ou do mal, mas perigoso em si mesmo, pois o seu não-desenvolvimento ou o seu desenvolvimento conduzido podem acarretar vários males ao seu portador.

Pela mediunidade o Mundo Visível e Mundo Invisível relacionam-se permanentemente através da comunicação espiritual e das comunicação espírita.

\section{A Comunicação Espiritual}

Um espírito encarnado está cercado dia-a-dia por uma população invisível que, sem que ele saiba, com ele se relaciona:

\footnotetext{
${ }^{5}$ Numa palestra a que assisti no ICEB, o expositor, cuja matéria se intitulava "A mediunidade e os Fatores Genéticos" abordou o problema da hereditariedade da mediunidade. Tratava-se certamente de "hipóteses", pois é fácil examinar a questão da descendência e herança dos caracteres adquiridos numa mosca drosófila que reproduz quatro a cinco gerações em uma semana. Mas como pegar uma drosófila e examinar o papel da mediunidade? (...) no terceiro milênio, a biologia terá certamente melhores condições para fornecer elementos" uma das hipóteses formuladas era a de que possivelmente um casal de médiuns terá um filho com tendências de mediunidade. Existiria nesse caso não só a herança cósmica espiritual transmissível de pai para o filho.
} 
Os espíritos agem constantemente sobre o mundo físico e sobre o mundo moral. São uma das potencias da natureza. Estão em toda parte, povoam os espaços até o infinito, há espíritos permanentemente ao nosso redor e com eles estamos em contato. (L.M:40)

Os espíritos cotidianizam-se, tornam-se parte integrante do mundo visível. Constituem e ao mesmo tempo explicam a ordem das coisas. No mundo natural, como agentes da vontade divina, os espíritos acalmam, agitam dirigem aos fenômenos da natureza. No mundo das relações humanas, os Espíritos desencarnados comunicam-se com seus iguais, os homens pelo atributo como que os caracteriza: o pensamento.

De todas as entidades que cercam um Espírito encarnado destaca-se a figura do seu mentor ou guia espiritual. O mentor é:

O responsável por nossa vida, por nosso trabalho geral. É quem nos instrui, nos consola, aconselha e orienta.

É o "anjo da guarda dos católicos". Trata-se geralmente de um Espírito superior que tem por missão velar pelo Espírito encarnado naquela existência. Além dessa entidade, os homens relacionam-se com os mais diversos Espíritos - amigos, inimigos, simpáticos, antipáticos, superiores, inferiores ou de grau evolutivo equivalente ao seu - ao seu acordo com teoria da afinidade ou das faixas vibratórias.

Os espíritos, como vimos,emitem, pela força de seu pensamento e de sua vontade, vibrações que agem sobre o fluído universal. A essa concepção da ordem do mundo físico, mescla-se outra, da ordem moral. As vibrações imprimem ao fluido o conteúdo moral do pensamento transmitido. O fluido universal decompõe-se em inúmeros fluidos que vão desde a pureza absoluta até a matéria palpável. Numa apostila do curso de médiuns ministrado no lar Tereza, essa gradação era definida da seguinte maneira:

Como odores eles são designados pelas suas propriedades, seus efeitos e tipos originais. Sob o ponto de vista moral, trazem o cunho dos sentimentos de ódio , de inveja, de ciúme, de orgulho, de egoísmo, de violência, de hipocrisia, de bondade, de benevolência, de amor,de caridade, de doçura etc. Sob ao aspecto físico são excitantes, calmantes, penetrantes, adstringentes, irritantes, dulcificantes, soporíferos, narcóticos, tóxicos, reparadores e expulsivos (...). O quadro dos fluidos seria,pois, o de todas as paixões, das virtudes e dos vícios da humanidade e das propriedades da matéria, correspondentes aos efeito que eles produzem

Essa fusão de duas ordens pensadas a princípio como distintas é central para a compreensão da visão e da vivencia da mediunidade entre os espíritas. Ela dá conta também, sobre outro ponto de vista, do que outros autores que estudam Espiritismo chamaram de seu caráter "místico" (ver capítulo I). Nessa religião o Moral e o Físico 
terminam por constituir-se uma só realidade. A mediunidade, que tem aqui o estatuto de uma prova irrefutável da existência dos Espíritos, é também inextricavelmente um serviço do Bem. Os médiuns são os missionários da luz, os mensageiros do Alto. As vibrações que emitem são de Amor, de Confiança, de Paz e Tranqüilidade.

Um conjunto de vibrações do mesmo conteúdo moral constitui o que os espíritas chamam de faixa vibratória. Segundo eles, o espaço atmosférico que cerca a Terra está hierarquizado nessas faixas vibratórias: dos planos mais inferiores e literalmente baixos, aos planos mais superiores e elevados. O Espírito encarnado, ao longo do seu dia, entra em sintonia com essas diferentes faixas vibratórias conforme seus pensamentos,atitudes e ações .Daí a freqüente metáfora de ser fulana ou sicrano uma pessoa elevada, este ou aquele lugar elevado.

Esse ponto é fundamental para a compreensão da relação homens/ Espíritos desencarnados. A influência dos Espíritos desencarnados é inevitável e permanente,exercendo-se através do pensamento a essa concepção combina-se, porém,o fato de que é Espírito encarnado quem dá a abertura, ou abre uma brecha ,só entrando em contato com espíritos com os quais entra em harmonia ou está com afinidade:

Nós funcionamos em faixas. Quando entramos em sintonia com faixas menos boas estamos sujeitos à influências dos espíritos que circulam nela.Os inimigos estão sempre atentos, nos observando e aproveitam os momentos de invigilância.

Ora, o livre - arbítrio do Espírito encarnado, responsável pela qualidade da vibração do pensamento que emite e que o contacta com Espíritos desencarnados, é, por definição, incompleto. De início, ele é limitado pelo determinismo divino. E, pela comunicação espiritual, ele é sempre potencialmente limitado pelo livre-arbítrio do Espírito desencarnado com quem se relaciona. O contato com Espíritos superiores é toda via limitação que garante a medida de exercício do livre-arbítrio humano. Inversamente como veremos no próximo item, o contato com Espíritos inferiores é possibilidade de aniquilamento desse atributo.

Essa influência cotidiana, difusa e imperceptível dos Espíritos, em cuja faixa o Espírito desencarnado está vibrando, é a influência sutil que pode estar na origem de vários sentimentos negativos ou positivos que o homem experimenta(alegria, melancolia, saudades etc.)

A comunicação do Espírito desencarnado com o homem pode assumir, Entretanto, formas menos sutis: 
Os Espíritos desencarnados podem agir sobre os nossos centros nervosos. Influem a tal ponto que às vezes os dirigem.

A esse fenômeno os espíritas chamam obsessão.

\subsection{A Obsessão}

Existem dois sentidos possíveis para obsessão. A Terra é, como tivemos oportunidade de ver no capítulo III, na discussão da caridade, um planeta de provações. Todos os Espíritos que a habitam estão ainda no percurso de sua evolução. São todos, com raras exceções, em certa medida inferiores. Como tais, esses Espíritos entram inevitavelmente em sintonia com Espíritos desencarnados inferiores. No seu sentido Mais amplo obsessão refere-se a esse fenômeno recorrente entre os homens. ${ }^{6}$

No entanto, obsessão tem também um sentido mais específico, usado com mais frequiência entre os espíritas:

Em consequiência da inferioridade moral de seus habitantes, grande quantidade de Espíritos inferiores circunda a Terra. A ação negativa desses Espíritos é parte integrante dos flagelos com que a Humanidade se vê a braços no mundo. Obsessão é o domínio que alguns Espíritos logram adquirir sobre certas pessoas e é praticada pelos Espíritos inferiores que se agarram àqueles a quem podem fazer suas presas. ${ }^{7}$

A obsessão tem seu início na influência sutil que os Espíritos desencarnados exercem sobre o homem e pode progredir até chegar à "perturbação completa do organismo e das faculdades mentais". Os espíritas distinguem três etapas ou tipos de obsessão:

1. A obsessão simples. Através da influência espiritual sutil, o Espírito mina as forças morais da vítima até que ela se torne incapaz de reagir.

2. A fascinação. O Espírito começa a agir diretamente sobre o pensamento do homem.

3. A subjugação. Fase final do processo obsessivo, correspondendo à paralisação total da vontade do Espírito encarnado:

O Espírito toma inteiramente o corpo do obsidiado e é ele inteira e unicamente o responsável pelos atos praticados (Apostila sobre Mediunidade).

A subjugação é uma possessão. Não há contudo, segundo os espíritas, coabitação de dois Espíritos num mesmo corpo. O obsessor se cola em toda a extensão do corpo de sua vítima e domina os centros de força e de energia orgânica.

\footnotetext{
${ }^{6}$ Ver, por exemplo, o seguinte comentário: "Todos nós espíritas em evolução na Terra temos a nossa cota de obsessão em maior ou menor grau."

${ }^{7}$ Apostila, $18^{\circ}$. Estudo da Mediunidade.
} 
A obsessão coloca em cena a dupla obsidiado/obsessor, um Espírito encarnado e um Espírito desencarnado inferior. O exame desses dois elementos é fundamental para a apreensão de seu sentido.

O obsessor, enquanto Espírito desencarnado, possui por definição um livre-arbítrio mais pleno no sentido em que um Espírito desencarnado é sempre Eu maior, guardando a memória de todas as suas vidas. Nesse estado, o Espírito, com o carma temporariamente suspenso, encontra-se necessariamente em presença da lei da reeencarnação, que é a possibilidade de seu progresso e de sua evolução (ver Diagrama 3, p. 48). Ao reencarnar, esse Espírito submeter-se-á novamente ao carma. A encarnação, como vimos, é provação. O ponto crucial, contudo, é que a reencarnação supõe o consentimento, a escolha do Espírito desencarnado. Não basta que ele sofra nela o seu carma, é preciso sobretudo que ele queira fazê-lo. Em algum momento do estado de desencarnado ele deve portanto arrepender-se.A reencarnação está assim condicionada ao arrependimento que garante o progresso do Espírito e o caráter expiatório da encarnação.

O obsidiado, por sua vez, é Espírito encarnado, Eu menor, com seu livre-arbítrio por definição incompleto e limitado, em plena trajetória evolutiva, em provação. Trata-se de um Espírito que escolheu reencarnar. Em outras palavras, trata- se de um Espírito que se submeteu à matéria, ao corpo, à expiação da encarnação porque aspira à evolução, ao estado de Espírito Puro, à perfeição.

Ora, o que ocorre na obsessão? O Espírito desencarnado obsessor é pelo fato mesmo de obsidiar, um Espírito que ainda não alcançou o arrependimento que é a condição de sua reencarnação. Sua inferioridade aproxima-o inexoravelmente da matéria com a qual permanece identificado. Ele busca no homem o corpo que perdeu ao desencarnar e que não pode ainda voltar a possuir pela reencarnação. Ele se submete à matéria não para transcendê-la mas simplesmente porque a deseja. Através de seu livre-arbítrio, de sua vontade, ele aniquila o livre-arbítrio do obsidiado. O homem, cujo espírito é dominado, reduz-se na obsessão exclusivamente a seu corpo, torna-se apenas matéria controlada por outro Espírito. A obsessão é nesse sentido uma dupla vitória da matéria sobre o espírito.

$\mathrm{Na}$ origem desse processo encontram-se, contudo, a vontade e o livre-arbítrio humanos. Pois, segundo a teoria da afinidade, para que um Espírito exerça influência sobre um Espírito encarnado é preciso que este dê abertura. Na origem do processo está o consentimento do Espírito encaro nado, "quer por fraqueza, quer por desejo". O homem, como o Espiritismo o concebe, vive num mundo ameaçador e perigoso. A primeira ameaça é ele mesmo, a segunda a influência dos Espíritos inferiores. Ele deve estar 
permanentemente em guarda. A melhor defesa é a constante vigilância de si mesmo, e a sua entrega no Serviço do Bem, e que garante a cobertura espiritual, ie., a proteção de Espíritos superiores.

Na obsessão, fenômeno que deriva da comunicação espiritual, da mediunidade em seu sentido amplo, enfraquecem-se os contornos entre os dois sentidos das noções de médium e mediunidade. O obsidiado é um médium no sentido estrito do termo, está em comunicação ostensiva com um ou mais Espíritos, mas é um médium às avessas, a serviço de Espíritos inferiores e sem o saber. É um "médium de energias perturbadas", um "enfermo, que representa uma legião de doentes invisíveis ao olhar humano". Temos o seguinte esquema:

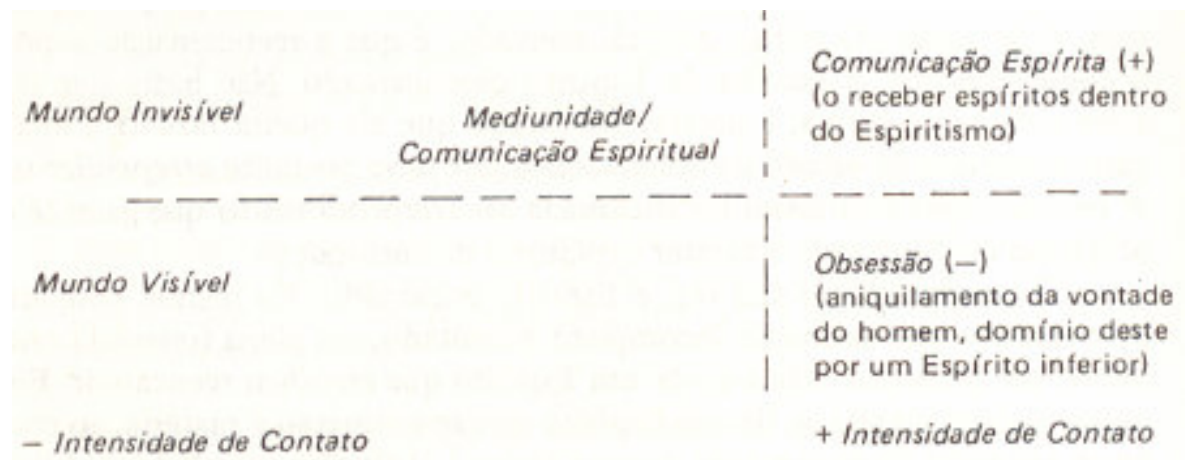

\section{Diagrama 7}

No eixo da diacronia, a relação entre o Mundo Visível e o Mundo Invisível implica do ponto de vista humano a fragmentação da identidade em Eu maior (Espírito errante e finalmente puro) e Eu menor (Espírito encarnado). Vimos no capítulo II, como o jogo entre livre-arbítrio do Espírito e determinismo divino possibilitava pensar e integrar na pessoa esses diversos "eus". Na mediunidade, segundo eixo com relação ao qual a noção da pessoa se constrói, esse jogo entre livres-arbítrios mais ou menos plenos ocupa também um lugar central.

A mediunidade, enquanto comunicação espiritual, afirma que o Mundo Invisível e o Mundo Visível existem em permanente relação. Na medida em que o homem, Espírito encarnado, existe em contato com outros Espíritos desencarnados, a comunicação espiritual é sempre um confronto de livres-arbítrios. De um ponto de vista, a obsessão, engendrando o

aniquilamento do livre-arbítrio humano, é uma antimediunidade, uma confusão entre os dois mundos: obsidiado e obsessor tornam-se um só personagem. O homem torna-se 
aquilo com que está em contato. Os limites entre os dois mundos se apagam, a relação entre eles transforma-se em identificação. De outro ponto de vista, a obsessão é uma antiencarnação

no sentido em que nela um Espírito inferior desencarnado se submete à matéria, obtém um corpo, sem pretender transcendê-lo. A obsessão é um congelamento da evolução.

Enquanto aniquilamento do livre-arbítrio do Espírito encarnado e enquanto domínio do corpo de outrem por parte do Espírito desencarnado, a obsessão representa o fim da condição humana. O livre-arbítrio é expressão e garantia dessa condição que repousa sobre a disjunção dos dois mundos, sobre sua relação ordenada pelas leis divinas.

No plano das representações espíritas explícitas esse confronto de livres-arbítrios configura uma tensão entre uma imagem do homem como um instrumento relativamente passivo dos Espíritos, de desígnios ocultos a ele, e do homem como guardando sua individualidade. A teoria da afinidade permite preservar na comunicação espiritual o livrearbítrio do Espírito encarnado. Contudo, se o homem está permanentemente influenciado por Espíritos, por outras vontades, mesmo que na base dessa influência esteja o seu livrearbítrio, único responsável pelas vibrações que emite, como distinguir entre o seu pensamento e o pensamento sugerido pelos Espíritos?

As distinções espíritas entre pensamento próprio e pensamento sugerido, entre o anímico (derivado do próprio Espírito) e o mediúnico (derivado do contato espiritual) traduzem essa tensão. Essa tensão está dada estruturalmente na medida em que, no homem, Espírito encarnado em evolução, o livre-arbítrio é necessariamente não-pleno, e em que ele existe em relação com outros Espíritos. A individualidade é sobretudo algo para que o homem tende. Sua realização plena só ocorre no estado de Espírito puro, quando o Espírito não mais reencarna, quando a oposição entre os Mundos Visível e Invisível é definitivamente transcendida, e o Espírito, formalmente perfeito, retoma a seu ponto de partida: Deus (ver o capítulo II).

Do ponto de vista desse sistema, a individualidade humana é por definição relativa e incompleta.

No ritual, os dois mundos se articulam por meio da mediunidade. A oposição entre eles é momentaneamente transcendida de maneira controlada, os dois mundos se conectam por meio de deslocamentos que garantem a cada um deles a sua integridade. Ao articular o visível e o invisível, a mediunidade problematiza a incompletude humana. Os rituais espíritas que lidam expressamente com a mediunidade conferem ao homem, enquanto agente social, mecanismos para refletir sobre, e construir, na relação com os Espíritos, a 
sua identidade.

\section{A Comunicação Espírita}

No plano do cotidiano, a permanente circulação de forças entre o Mundo Visível e o Mundo Invisível é em sua maior parte sutil, implícita, e sobretudo não-controlada do ponto de vista humano. A comunicação espírita, inscrevendo-se nesse circuito, pretende direcioná-Io, trabalhá-lo, na medida em que isso é possível aos limites terrenos. No lado humano de seu cenário, o médium emerge como o personagem central.

\subsection{O Médium}

O médium, no seio do Espiritismo, é aquele que desenvolve sua mediunidade no sentido do Bem, transformando o dom que todo homem possui em mediunidade ostensiva, num processo que os espíritas chamam de desenvolvimento da mediunidade.

Desenvolver, juntamente com iniciar-se em/aceitar a doutrina eram as duas expressões com as quais as pessoas que foram entrevistadas por mim referiam-se a sua aproximação de, e seu ingresso em, o Espiritismo. Nunca escutei da parte de nenhum espírita o termo conversão. O tornar-se espírita não é representado como um ato de fé, mas, ao menos idealmente, como um compromisso sempre crescente com a doutrina. Yvonne Velho (Velho, Y; 1975: 118) chama atenção para o fato de que, no terreiro de Umbanda por ela estudado, a conversão não se dá num momento específico, num momento de crise como alguns autores o afirmam (Camargo, 1961). Mesmo havendo um momento decisivo, as biografias dos agentes envolvidos mostravam como antes eles já estavam em contato com elementos daquele código simbólico. O mesmo pode ser dito com relação ao grupo por mim pesquisado.

$O$ iniciar-se na doutrina enfatiza o contato com a literatura espírita, o estudo, a reflexão, a aceitação consciente de seus princípios. Desenvolver refere-se ao contato com a mediunidade e o transe. Os dois movimentos não são excludentes. Em alguns relatos um deles antecede o outro ou vice-versa. No caso da ênfase no desenvolvimento, a aceitação da doutrina é um momento que aparece necessariamente mais cedo ou mais tarde. $\mathrm{O}$ mesmo não ocorre com a ênfase na aceitação da doutrina, que pode subsistir sozinha, pois, embora como qualquer homem todo espírita seja um médium, ele não desenvolve necessariamente sua mediunidade de maneira plena.

Apresento a seguir dois relatos nos quais os dois movimentos de aproximação do Espiritismo são particularmente claros. 
O primeiro deles é o de Deolindo, casado, pai, avô, jornalista aposentado, originário da Bahia, morador de um apartamento em Ipanema. Sua familia era católica. Ainda na Bahia, na década de 1920, Deolindo tonou-se presbiteriano, tendo escrito nessa época nos jornais locais vários artigos "anticlericais e que visavam à liberdade da crença". ${ }^{8}$ Por achar as exigências dessa religião demasiado rigorosas, deixou-a. Chegou ao Rio, aonde viera "tentar a vida" aos 20 anos, numa fase de

terrível descrença. Duvidava de tudo dos homens e de mim mesmo.

Morava em São Cristóvão. Um dia um amigo deu-lhe para ler um livro espírita, e, alguns meses depois levou-o a um centro, localizado em Bento Ribeiro. A reunião, porém, não o convenceu. Chegou às suas mãos o Livro dos Espíritos.

Era carnaval, fui para Valença, tranquei-me num quarto de pensão e voltei de lá vendo o mundo por um prisma diferente.

O conhecimento dos fenômenos, contudo, seria antigo, sua mãe tinha visões e em sua casa certa vez um de seus tios foi perseguido por um Espírito.

Mas

foi a doutrina que me trouxe (...) entrei no Espiritismo pela porta da dúvida.O Espiritismo, sua filosofa, preencheram o vazio de minha alma.

Deolindo fundou um centro, participou durante muito tempo da Liga Espírita (entidade que deu origem à FEERJ) e da Faculdade Brasileira de Estudos Psíquicos, foi posteriormente um dos fundadores do ICEB.

Um relato distinto é feito por Violeta, viúva de militar, mãe, avó,funcionária pública aposentada, moradora de um apartamento na Lagoa, originária de Pernambuco. Sua família era católica. Ela, também católica, detestava, no entanto, confessar-se, detestava a figura intermediária do padre, opondo a isso o seu gosto pela oração, vista como "uma coisa

direta e íntima". Segundo ela, em 1941, já casada, mãe de duas filhas, e morando no Rio de Janeiro, sentiu o primeiro "sinal". Começou a ter visões e premonições. Uma amiga espírita disse-lhe que precisava desenvolver, mas ela não levou a sério. O marido opunhase. As visões e premonições continuaram. Só veio a desenvolver dez anos mais tarde,

\footnotetext{
${ }^{8}$ Segundo Deolindo, houve nessa época um movimento grande que congregava protestantes, espíritas e maçons contra o que se chamou de "Emenda Religiosa". Em 1925 - 26 na Reforma da Constituição no Governo de Artur Bernardes estava prevista a Inclusão do ensino religioso nas escolas, contra o que se manifestaram os grupos mencionados.
} 
"pelo sofrimento". No trabalho, em casa, na rua, ela repentinamente desmaiava. Exames médicos revelaram alto grau de disritmia. A doença progrediu, deixando-a num estado de crescente incapacitação. Obteve então licença médica no trabalho teve sua carteira de motorista invalidada. Uma amiga de sua mãe, diretor de um centro espírita, disse-lhe que eram manifestações de sua mediunidade, um sinal para desenvolver. Ela comunicou ao médico que ia freqüentar um centro espírita. Ele recomendou-lhe que não o fizesse, pois "agora mesmo é que eu ia ficar louca". Ao que Violeta respondeu que preferia ficar louca a continuar tomando remédio e se sentindo mal. Começou então a "iniciar-se na doutrina", freqüentava no centro sessões de estudo doutrinário e desenvolvimento. Aos poucos foi tirando os remédios e obtendo todos os documentos de novo. Quando sua cura espiritual se completou, começou a trabalhar como médium e colaboradora no centro referido, Desde então não deixou de "militar".

Como o relato de Violeta evidencia, em determinado momento da vida de uma pessoa, sua medi unidade começa a manifestar-se. A compreensão dessa expressão remete num primeiro momento à dicotomia derivada da representação espírita da pessoa entre Eu maior e Eu menor (ao Espírito no estado de desencarnado e ao Espírito no estado de encarnado). Num segundo momento, à idéia da comunicação espiritual.

Vimos no capítulo II como na encarnação o Espírito é apenas seu Eu menor, um fragmento de sua identidade plena, de seu Eu maior. Mesmo encarnado, preso a um corpo, sua natureza é espiritual, ele permanece essencialmente Espírito. Como todo prisioneiro, dizem os espíritas, ele procura fugir, e algumas vezes foge de fato. Na verdade, um Espírito encarnado jamais abandona totalmente o seu corpo, os laços que unem perispírito ao corpo apenas se afrouxam, o Espírito permanece ligado a seu corpo, ainda que brandamente. Esse afastamento do Espírito do seu corpo toma duas formas que se inscrevem no cotidiano dos homens:

1. a primeira delas é o sonho. Diariamente, durante o sonho, o Espírito encarnado recobra sua liberdade, passeia pelo Mundo Invisível, comunicando-se com seus habitantes. $\mathrm{O}$ que chamamos de sonho não são senão lembranças mais ou menos nítidas que o Espírito, ao retornar à sua "prisão", guarda desse convívio;

2. a segunda delas assume formas mais brandas como visões e premonições, ou formas mais graves que podem gerar doenças como a letargia, a disritmia, a catalepsia e o sonambulismo. Segundo os espíritas, esses fenômenos são provocados pelo abandono parcial do corpo pelo Espírito. 
Ambos os fenômenos são qualificados de anímicos, reveladores de faculdades inerentes ao Espírito. Pois cada Espírito encarnado, enquanto Eu menor, traz guardadas em si mesmo lembranças e potencialidades infinitas, acumuladas em todas as suas vidas. Esse repertório oculto é por vezes trazido à tona suavemente ou de maneira mais abrupta por meio das formas cotidianas de afrouxamento do laço perispírito-corpo.

A segunda forma dessas manifestações é sinal de vibrações espirituais intensas, como dizem os espíritas, sinais para desenvolver. Se não são tratadas, essas vibrações geram vários males, podendo levar entre outras coisas à obsessão, à depressão e ao suicídio. O desenvolvimento da mediunidade direciona essas vibrações. Nela, o afrouxamento do laço perispírito-corpo é supervisionado pelo próprio Espírito (ver mais adiante, p. 117). Muito embora ele não seja considerado o tratamento exclusivo - em alguns casos, a pessoa não tem condições espirituais para assumir a tarefa de tornar-se médium; em outros, pode-se recorrer ao tratamento de cura espírita propriamente dito passes, operações fluídicas, bem como ao tratamento da medicina oficial - só ele restaura plenamente o equilíbrio psíquico e orgânico da pessoa.

A mediunidade ostensiva é vista como uma mediunidade de tarefa, e um "compromisso assumido com o Plano Espiritual", uma missão a ser cumprida ao longo da Encarnação. Os termos que a qualificam são idênticos aos que qualificam a encarnação. Trata-se na mediunidade também de uma provação, de uma expiação, de um testemunho, de uma "oportunidade que por misericórdia Deus dá ao homem". E de fato, como veremos, a mediunidade é uma metáfora da encarnação. Idealmente os Espíritos poderiam dispensar a figura do médium, comunicando-se diretamente com cada homem. Uma das razões que os espíritas dão para que isso não ocorra é esse caráter expiatório que a mediunidade tem. Além do fato de que, para o paciente, para aquele que vem procurar o centro espírita, bem como para o Espírito inferior que se manifesta em algumas sessões, "o médium significa maior materialidade". Com isso os espíritas' querem dizer duas coisas: que, por ser, como todo Espírito encarnado na Terra, em certa medida inferior, o médium capta e transmite melhor as vibrações e necessidades do Espírito encarnado ou desencarnado a quem socorre; e que, da parte do paciente, a figura do médium, palpável, reforça sua crença. Como a matéria, a inferioridade, a imperfeição, a mediunidade é parte da ordem das coisas, ela existe porque o mundo e os homens são imperfeitos.

Seu exercício requer antes de tudo que o médium seja um bom espírita, o que supõe as duas outras dimensões da vida religiosa espírita: o estudo e a caridade. O conhecimento da doutrina é indispensável. O médium deve ler e refletir diariamente. A prática da 
caridade é igualmente importante. Através do amor ao próximo assim expresso, o homem aprimora seu Espírito e garante a cobertura do Plano Espiritual. Tanto a caridade Como o estudo enfatizam o papel do homem (Espírito encarnado) que se fortalece como individualidade, trabalhando o seu próprio Espírito. O contato direto e explícito com o Mundo Invisível requer esse fortalecimento. Em primeiro lugar porque, como vimos, cabe ao médium imprimir à sua mediunidade o conteúdo moral adequado. Em segundo lugar porque a mediunidade permanece sempre potencialmente perigosa. Para enfrentar esses perigos, o médium deve gozar de saúde espiritual, i.e., deve vibrar na faixa mais elevada possível, o que depende de seu comportamento. Desse modo, "Eles (os Espíritos inferiores) chegam, batem, vão embora. Não entram não". O médium, a partir da vigilância e do autodomínio, deve esforçar-se

por reajustar os bons sentimentos, por pautar sua vida pelos princípios do amor e da caridade.

Há assim um conjunto de sentimentos que definem não só o médium como a maneira de ser espírita: o médium deve ter confiança, no Plano Espiritual, nos dirigentes do grupo, no trabalho e em si mesmo, deve ter boa vontade, paciência, discrição. Sentimentos que se expressam numa conduta digna, correspondendo a vibrações espirituais elevadas. A eles opõem-se.

(...) a cólera, a irritação, a leviandade, a maledicência, a crueldade, a calúnia, a irreflexão, a brutalidade, a tristeza, o desânimo, a vaidade,

que

produzem elevada percentagem de radiações mentais de natureza destrutiva, em nós e em torno de nós, suscetíveis de fixar-nos por tempo indeterminado em deploráveis labirintos de desarmonia mental.

Além desse preparo de ordem geral, no dia da tarefa mediúnica o médium deve ter cuidados especiais com a alimentação. Convém evitar comidas pesadas, gordurosas, bebida alcoólica, cigarros, remédios em geral.Deve comer horas antes do início da tarefa para que o processo da digestão não absorva energias que são destinadas a. outros fins. $\mathrm{O}$ fluxo sanguíneo e o corpo fluídico devem estar o mais puros possível, pois o cérebro trabalhará com grande intensidade. Se essas recomendações não são atendidas, o organismo será sobrecarregado pelo trabalho mediúnico, produzindo dores de cabeça, náuseas, mal-estar no médium. Todo esse preparo é necessário, pois mais do que ninguém ele está sujeito à influência espiritual sutil: 
o médium irradia uma força positiva, é um foco de luz que atrai Espíritos que querem se

beneficiar (Apostila sobre Mediunidade).

Além disso, como todo homem, o médium é também imperfeito, trazendo à sua volta Espíritos imperfeitos. Ele é, segundo os espíritas, muito assediado por Espíritos inferiores. Cabe ao médium reagir com vibrações positivas que o põem em contato com Espíritos superiores. Essa luta é o ônus do trabalho mediúnico, sua provação, seu testemunho.

\subsection{As Formas de Comunicação Espírita}

No centro pesquisa do eram três as formas ostensivas de comunicação com os Espíritos: $a$ prece, o passe, e a manifestação mediúnica. Essas modalidades de contato são claramente distintas entre si. Mas, por implicarem todas um contato direto com o Mundo Invisível, aparecem nos rituais freqüentemente associadas. O passe e a prece são parte do repertório da quase-totalidade das sessões. A manifestação mediúnica é exclusiva das sessões definidas como mediúnicas, o desenvolvimento mediúnico, a irradiação e a desobsessão. Examino a seguir cada uma dessas formas.

\section{a. A Prece}

Todo Espírito emite vibrações que se imprimem nos fluidos. Os espíritas chamam a essa faculdade capacidade de irradiação. Como tudo o mais, ela depende da elevação espiritual de cada um. Quanto mais evoluído, tanto mais elevados os planos que a irradiação de um Espírito encarnado pode alcançar. A prece é uma irradiação de vibrações positivas, de vibrações de amor. Ela é definida como "uma evocação para os bons Espíritos", a qual

coloca o homem em sintonia com Espíritos superiores, inspira intuições para resolver problemas, colabora com a cura, repele o assédio de Espíritos perturbadores, fluidos deletérios, vibrações maléficas (Apostila sobre Mediunidade).

Como diz o Espírito André Luiz (in Os Mensageiros, psicografado por Chico Xavier):

o homem que ora traz consigo inalienável couraça. O lar que cultiva a prece se transforma em fortaleza.

Embora haja algumas preces padrões, como um Pai-Nosso espírita, e hinos que são preces cantadas por todos, a prece espírita é sobretudo uma criação de quem a faz:

É aconselhável abandonar o quanto possível as fórmulas decoradas, a leitura maquinal de 
"preces-prontas", e viver preferencialmente as expressões criadas de improviso, em plena emotividade na exaltação da própria fé. ("André Luiz pelo médium Chico Xavier", in A Conduta Espírita.).

De fato, as preces devem ser vividas, mais do que simplesmente ditas. Devem corresponder integralmente ao sentimento de quem as profere. Podem ser feitas a qualquer hora, em qualquer lugar. São um meio de socorro, recursos indispensáveis do médium, para dúvidas e demais ordens de dificuldades. No centro, em todas as sessões há pelo menos duas preces, ambas feitas na penumbra e nas fases inicial e final de um ritual. São geralmente acompanhadas pelo som de um disco de música clássica ao fundo. Quem a profere cerra os olhos e fala numa voz suave, pausada, algo musical:

Elevemos nosso pensamento a Jesus, a Sheila, Antônio de Aquino, Tereza... Peçamos a eles que nos amparem na tarefa que vamos iniciar. Vamos concentrar-nos, para que possamos aproveitar a mensagem que nos trazem, as energias e vibrações positivas. (...) Pensemos em todos os necessitados, no campo politico do qual rufo participamos e enviemos vibrações positivas ${ }^{9}$.

Quem ora, emitindo vibrações positivas, entra em sintonia com o Alto. Pois, para que os Espíritos superiores venham até os homens, é preciso que estes cheguem até eles. $\mathrm{Na}$ prece, o homem tem uma. parte ativa, pois ela é pessoal, é emissão de vibrações. Mas, através dela, o homem, embora capaz de alcançar o Alto, se proclama, diante dos Espíritos superiores, fraco, limitado e carente. A prece é um pedido de ajuda, de amparo. Como fala que estabelece uma ligação com o Alto, a prece está sujeita a várias combinações, reforçando, complementando algum outro elemento ritual. É freqüente sua associação ao passe,

desobstruindo a mente de impurezas, ela oferece livre passagem para os fluidos dos Espíritos e garante a pureza dos fluidos humanos (Apostila sobre Mediunidade).

Como o passe, ela é um auxilio inestimável na psicografia e na incorporação (ver item c). E há uma sessão, chamada sessão de irradiação, que tem na prece o seu foco. ${ }^{10}$

A irradiação é uma sessão feita para aqueles que deixam seus nomes no centro e todos que vão ao centro, especialmente os que freqüentam o atendimento fraterno e as

\footnotetext{
${ }^{9}$ Prece proferida numa Reunião Pública.

${ }^{10}$ Durante o ano de 1980 não ouvi menção a essa sessão, que talvez de fato não existisse como tal. No centro, a irradiação, i.e., emissão de vibrações positivas, ocorria diluidamente ao longo de todas as sessões mediúnicas não exclusivamente destinadas a esse fim. Em 1981, quando retomei a pesquisa para conclú́-Ia, havia à noite duas turmas de desenvolvimento mediúnico que se revezavam semanalmente. Sempre que o mês tinha cinco semanas, realizava-se na última uma sessão de irradiação. Duas diretoras de departamento faziam uma irradiação exclusiva delas. Uma médium que trabalhava na desobsessão participava com duas amigas de uma irradiação em casa de uma delas. Tive oportunidade de assistir a apenas uma sessão de irradiação.
} 
obras de assistência, i.e., o público que é objeto da caridade. A compreensão dessa sessão complementa a discussão da caridade desenvolvida- no capítulo III. Trata-se de uma sessão de vibrações de amor. Como em toda sessão mediúnica, todos devem manter o pensamento e a vontade firmes, mas nesse caso "devem expandir sobretudo o lado emotivo". Não se deve pensar nas pessoas diretamente, mas em Jesus e através de Jesus, nelas. Os médiuns emitem vibrações e os Espíritos "distribuem esses recursos". É uma sessão de preces e hinos.

A sessão se realiza no aposento aos fundos do segundo andar, e a ordenação do espaço, que difere tanto das sessões de desenvolvimento e de desobsessão quanto das sessões de estudo pode ser representada da seguinte maneira:

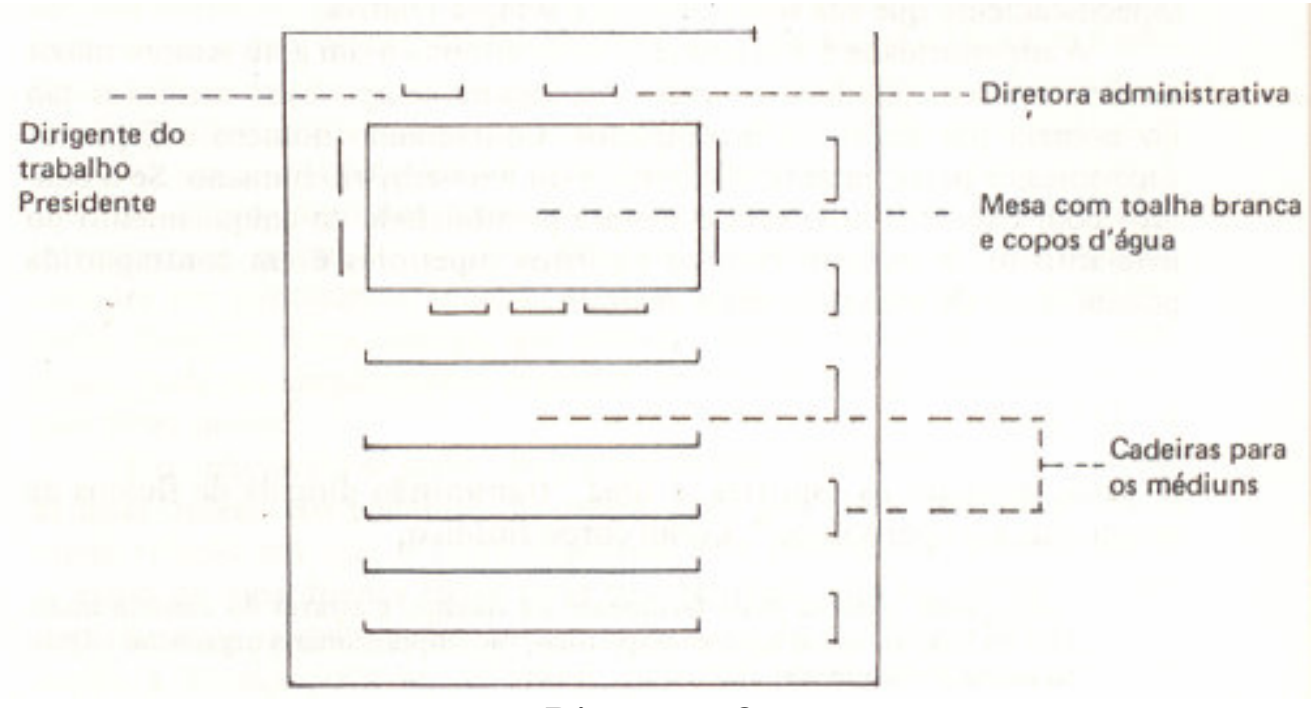

Diagrama 8

Como as demais, essa sessão se inicia pela preparação do ambiente (ver p. 65). Apagadas as luzes, acesas as lâmpadas azuis, a dirigente do trabalho, Betânia, designa um a um alguns dos médiuns que fazem uma prece. As preces, intercaladas por hinos cantados por todos, são pequenos desempenhos individuais. De olhos fechados, com a mão sobre a testa, o orador começa falando baixo, aos poucos sua voz se eleva e ganha um tom emocionado. Ao final, alguns chegam a chorar. Ora-se pelos velhinhos, pelos pobres, pelos órfãos, pelos doentes, por todos os necessitados, e finalmente por eles mesmos. Ao final, um dos médiuns recebe o "pronunciamento do Plano Espiritual". Todos recebem passes individuais e bebem água fluidificada.

$\mathrm{Na}$ verdade, na medida em que a irradiação é uma sessão mediúnica, feita pelos médiuns para o público que é objeto da caridade, e na medida em que ela focaliza a prece, que é um componente de todas as tarefas espíritas, ela não só reforça uma dimensão da 
prática espírita já indicada na discussão da caridade (o lado humano fraco e carente dos espíritas) como permite a extensão dessa dimensão para a totalidade dessa prática. $\mathrm{Na}$ prece, tal como realizada na irradiação, os médiuns enfatizam a dúvida, a dificuldade, a hesitação, a desproporção entre a grandeza da tarefa que têm pela frente e a pequenez de suas possibilidades. Enquanto um dispositivo que garante a presença e participação dos Espíritos em todas as tarefas, a prece coloca os médiuns diante do terceiro elemento que define todos os homens como fracos, o Plano Espiritual. Ela lembra permanentemente aos homens sua subordinação ao Mundo Invisível. Ela lembra aos médiuns especificamente que sua superioridade é sempre relativa.

A superioridade é equacionada nesse sistema a um grau sempre maior de livrearbítrio e individualidade. Ao mesmo tempo esses atributos são no homem por definição incompletos. Contactando homens e Espíritos superiores, a prece garante o exercício do livre-arbítrio humano. Se o contato com Espíritos inferiores é sempre possibilidade de aniquilamento do livre-arbítrio, o contato com os espíritos superiores é em contrapartida possibilidade do exercício desse atributo.

b. O Passe

O passe, segundo os espíritas, é uma "transmissão dirigida de fluidos de perispírito para perispírito". Como corpo fluídico,

o perispírito assimila mais facilmente os fluidos, e através do contato molecular os fluidos,como agente terapêutico, vão impressionar o organismo (Apostila sobre Mediunidade).

O passe é uma troca fluídica entre o Mundo Visível e o Mundo Invisível.

De acordo com a fonte da energia transmitida, os passes podem ser divididos em três tipos:

1. o passe espiritual, dado pelos Espíritos que, utilizando seus próprios fluidos, atuam diretamente sobre os Espíritos encarnados; ${ }^{11}$

2. o passe magnético, em que as energias transmitidas são do próprio médium, que "doa sua força irradiante". Geralmente, segundo os espíritas, esse passe é dado por pessoas sem credo nenhum.

3. o passe mediúnico, no qual a figura do médium é central, servindo de veículo para

\footnotetext{
${ }^{11}$ Na Federação Espírita de São Paulo há câmaras para esse passe que me foram aSsim descritas: "São cômodos reservados, de teor vibratório fluídico alto e sempre purificado, no qual são introduzidos os necessitados, que ali permanecem em silêncio enquanto os Espíritos desencarnados os assistem sem interferência dos encarnados.
} 
os fluidos que os Espíritos doam. Contudo, nessa transmissão, o médium sempre doa um pouco de seus próprios fluidos, daí esse passe chamar-se também de magnetismo misto. O passe espírita é o passe mediúnico.

O passe tem um duplo objetivo: o físico (orgânico) e o moral (espiritual):

é uma modalidade de socorro fraterno aos que sofrem do corpo e da alma.

Na verdade, como já tivemos a oportunidade de ver, a ordem do moral e do físico remetem uma a outra, terminando por se fundirem. Os fluidos são um elemento da ordem do físico, transmissores de vibrações que acabam contudo por ter um conteúdo essencialmente moral. O homem é uma totalidade composta das duas ordens. Nele, o que é orgânico/material e o que é espiritual estão em permanente relação por meio do perispírito, que combina em si as duas ordens e ordena as passagens entre o corpo e o espírito. No corpo imprimem-se as marcas da conduta moral do Espírito e, inversamente, o que um Espírito faz com seu corpo marca o seu espírito.Embora em permanente relação, as duas ordens são pensadas a princípio como distintas. Uma doença, que acarreta sempre conseqüências no espiritual, pode ser simplesmente orgânica no sentido em que sua causa se origina nesse plano.

Reconhecendo-se assim um espaço de uma certa autonomia do físico, as duas ordens são pensadas, na maior parte das vezes, como imbricadas numa relação em que o moral/espiritual tem precedência sobre o físico.A causa de uma doença física pode ser espiritual, seja ela cármica - produto do mau passado do Espírito, e nesse caso, do ponto de vista da encarnação, a doença pode ser incurável, pois "só terminará quando a dívida for quitada" - ou produto da comunicação espiritual. Na verdade está em jogo uma concepção particular do que seja o físico: o corpo humano é uma parte apenas dessa totalidade composta de espírito, perispírito e corpo, que é o homem, e em relação a ela deve ser entendido. Assim sendo, no passe o objetivo moral sobrepõe-se ao físico, pois o que importa é sobretudo a "renovação do comportamento das criaturas". As doenças cármicas podem não ter cura nessa encarnação, mas

mais importante que a recuperação física é a recuperação espiritual (Apostila sobre Mediunidade),

pois esta última inclusive reverterá a longo prazo naquela.

O passe estabelece uma relação entre quatro elementos: o Espírito/doador; o médium/transmissor e em parte também doador; o paciente, doente ou enfermo, como é 
chamado/receptor; e o(s) Espírito(s) inferior(es) que se comunica(m) com este último/receptor indireto. Essa relação pode ser representada pelo seguinte esquema:

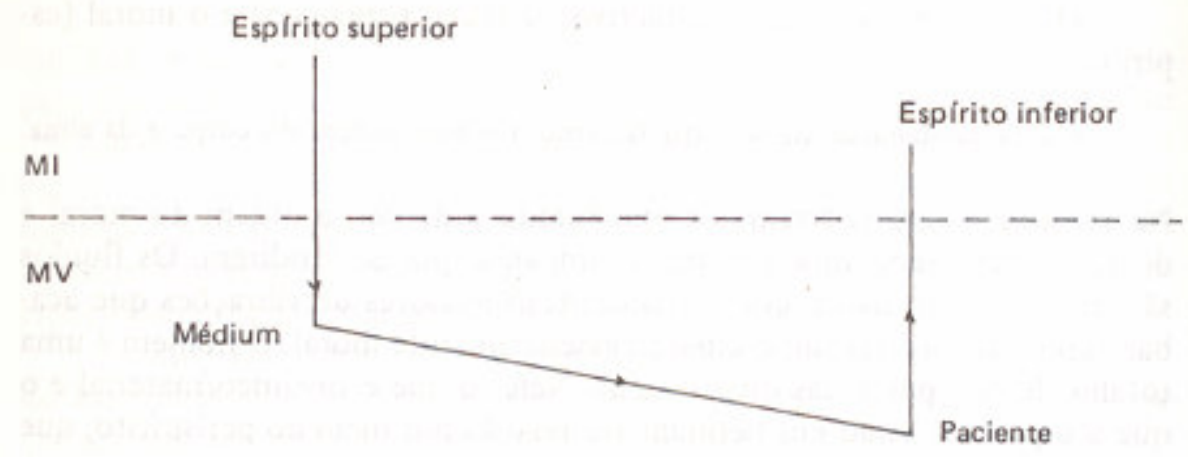

Diagrama 9

Sua eficácia depende dos três primeiros elementos. A presença espiritual é garantida pela prece. A capacidade de transmissão do médium passista depende de sua conduta e de seu preparo ritual. A capacidade de absorção do paciente depende também de sua conduta, de sua atitude de boa vontade. É preciso que este último esteja em condições de beneficiar-se. Para tanto conjuga-se o passe ao estudo do evangelho, é a

Evangelho terapia, que tem como objetivo tornar o enfermo resignado, fazê-la compreender o porquê de suas dores, que mais importante é a sua recuperação espiritual.

Mas o passe implica também uma técnica específica. Esse é um ponto polêmico entre os espíritas.

Assisti certa vez no lCEB a uma mesa-redonda acerca da existência ou não de uma técnica própria do passe. Algumas pessoas defendiam a inexistência de uma técnica, outras a sua existência. A primeira posição baseavasse no fato de que o passe dependia sobretudo do Plano Espiritual, das circunstâncias. A segunda baseava-se no seguinte argumento:

Jesus ao dar o passe simplesmente punha as mãos porque ele sabia controlar os fluidos, Porém uma imposição demorada de fluidos pode piorar. (...) À s vezes, lá no centro, o paciente sai da sala de passes com dor de cabeça, e eu, que tenho experiência, desfaço tudo e faço tudo de novo. (...) Por vezes é só nos sentarmos ao lado de um paciente que ele melhora. É o Plano Espiritual. Mesmo assim, a técnica não pode ser dispensada. Ela é necessária porque não sabemos simplesmente dosar os fluidos, então fluidificamos todos os centros de força.

O primeiro argumento enfatiza a imagem do homem como um instrumento passivo dos Espíritos; o segundo defende a técnica em nome de uma maior importância da instância humana. O médium transmite, é certo, mas essa transmissão é controlada pelo bom 
médium, como o era Jesus. Na falta dessa capacidade, a técnica, uma invenção humana, supre essa deficiência.

No Lar de Tereza, como no GEAL, aceita-se a técnica. O passe é, como eles dizem, padronizado, o que significa que ele obedece a determinadas normas, que são conformes à orientação da Federação. Segundo um médium, contudo,

antes de sair este artigo onde se falava da necessidade de padronização, nós aqui já estávamos fazendo isso. E recebeu-se mensagem dos Espíritos em várias casas para que o passe fosse padronizado. Isso nos deu muita segurança, sentimos que estávamos filtrando o pensamento dos Espíritos,

O centro é o lugar mais indicado para o passe, seja pelo fato de que lá o ambiente espiritual é mais puro e elevado, o que produz maiores possibilidades de troca fluídica, seja porque o passe deve estar associado ao estudo do evangelho, da doutrina. Mas, quando alguém doente não pode ir ao centro, recorre ao passe em casa. Esse passe, porém, deve cercar-se de cuidados. O ambiente espiritual da casa é desconhecido. Pode ser a tal ponto "pesado" que um médium sozinho não consiga suportar. Recomenda-se então que o médium vá sempre acompanhado, de modo que "um sustenta o outro e a gente não se expõe demasiado". Está em jogo também a concepção espírita de sua religião:

a pessoa doente, tudo bem. É uma exceção, um caso especial. O que não pode é o vizinho saber, vir pedir, porque passe sem esclarecimento não cura ninguém.

No Lar de Tereza distinguem-se três tipos de passe mediúnico:

1. o passe coletivo, que recebe esse nome porque um médium doa fluidos a mais de uma pessoa ao mesmo tempo. É o passe dado nas Reuniões Públicas na sua fase final. Os médiuns presentes erguem-se, colocando-se na extremidade de cada fileira de cadeiras, levantando os braços dobrados, com as palmas das mãos abertas, voltadas para as pessoas, os olhos cerrados. O receptor permanece sentado, as pernas, pousadas sobre o chão, não devem estar cruzadas (o que facilita a circulação de energias), os braços descansando ao longo do corpo com a palma da miro voltada para cima sobre as pernas, os olhos cerrados. Esse passe dura geralmente de três a cinco minutos. Após o seu término, os pacientes permanecem sentados aguardando a distribuição de água fluidificada pelos Espíritos ao longo da sessão;

2. o passe individual, no qual cada médium atende uma pessoa. Esse passe é dado pelo médium de pé diante do paciente e comporta dois movimentos. O primeiro deles é o de dispersão dos fluidos: os braços do médium erguem-se em torno do corpo do paciente, 
as miras se fecham, recolhendo fluidos negativos. Os braços abaixam-se e as mãos, com as palmas para trás, se abrem, jogando fora os fluidos recolhidos. O movimento é repetido quantas vezes o médium julgar necessário. O segundo é a vibração, a reposição de fluidos bons. As mãos podem ficar simplesmente vibrando com as palmas voltadas para a cabeça do paciente sobre a epífise, ou percorrer também os demais centros de força do corpo. Podem mexer ou não depende do médium, "do que ele captar". Em ambos os movimentos, o médium deve orar mentalmente pelo paciente. O término do passe é indicado por um leve toque do médium no ombro do paciente. Esse passe é dado nas reuniões de tratamento e nas reuniões mediúnicas.

Há um tipo especial de passe individual chamado passe na cabina, destinado exclusivamente a pessoas com problemas de ordem física. É dado num aposento à parte, reservado para esse fim após as entrevistas na sessão de atendimento fraterno. Nesses dois passes o paciente permanece na postura de recepção já indicada

3. finalmente o autopasse, passe que o próprio médium se dá, sentado ou em pé, ao longo das reuniões exclusivamente mediúnicas, geralmente após o transe. É "uma ajuda para desconcentrar fluidos negativos" que se fazem presentes através dos Espíritos inferiores que comparecem às reuniões. Compõe-se dos dois movimentos acima indicados.

Há duas normas que devem ser respeitadas na efetivação do passe:

1.A primeira é a de que o toque no paciente deve ser evitado. O toque é tido como desnecessário, pois a proximidade das mãos já garante o contato com a aura, o corpo fluídico, do doente:

Está certo que o Espírito vibre, mas a gente às vezes continua a vibração e daqui a pouco estamos esbarrando no doente.

Por outro lado, não tocar o paciente é uma precaução, pois, como me disse uma das médiuns,

as pessoas que nos procuram trazem uma série de coisas que não conhecemos. Não sabemos o que vai causar ao desequilibrado o toque. Temos de estar atentos. Somos humanos; o toque pode provocar reações negativas, desconcentra o paciente, às vezes são pessoas com distúrbios sexuais... Podem pensar que o médium é um aproveitador.

Apesar dessa recomendação, algumas vezes em que tomei passe, este implicava um toque ligeiro, suave. E, no passe na cabina, o toque é permitido, pois esse passe é considerado especial, visando a "um problema mais difícil". O toque é aí da mesma ordem que o problema tratado: físico.

Essa questão do toque era, contudo, reconhecida expressamente como um motivo de 
polêmica entre os espíritos. Um dos médiuns em desenvolvimento no Lar de Tereza trabalhava em outro centro onde o passe era dado com toque. Sabendo desse fato, a dirigente de desenvolvimento comentou:

cada casa tem a sua direção espiritual. Os Espíritos não são robôs, têm a sua individualidade. Agora, os mentores são disciplinadíssimos. Então, lá você toca, aqui não. Sabemos que há médiuns que tocam, mas não podemos achar que somos exceção.

Além do que,

é preferível seguirmos o caminho que a lógica nos conduz. E a experiência de algum tempo que estipula essas regras.

A recomendação dos Espíritos e a experiência surgem como planos de explicação complementares na implementação da norma do não-toque.

2. A segunda norma é que se evite a manifestação mediúnica na hora do passe. $\mathrm{Na}$ hora do passe, os Espíritos envolvem o médium, o que torna próxima a possibilidade da ocorrência de uma incorporação. Esta, porém, deve ser evitada:

Às vezes é comum nos sentirmos mediunizados do cotovelo para baixo. Sentimos um peso,ou uma leveza (...) O braço é pura eletricidade (...) mas a incorporação não deve ser dada.

O passe está no limiar da manifestação. No que toca aos Espíritos, estes

são disciplinadíssimos. Se há uma diretriz da casa eles estão a par disso. E o guia os dirige.

Quanto ao médium, deve controlar-se. Entretanto, a manifestação pode por vezes ocorrer:

se há a manifestação, há uma razão para que ela ocorra. Não devemos provocá-la (...) os Espíritos que comandam às vezes permitem que isso aconteça se damos abertura.

Essa possibilidade é presente também para o receptor do passe. Nesse caso, ocorrendo a manifestação, aconselha-se que o médium se dirija à própria pessoa e não ao Espírito, dizendo-lhe que se concentre, que desperte, que não é hora de o Espírito manifestar-se, mas sim de ela receber ajuda. Todavia, há casos em que o Espírito precisa manifestar-se e deve ser atendido. ${ }^{12}$

É a forma e a intensidade do contato entre o Mundo Visível e o Mundo Invisível o que distingue o passe da manifestação mediúnica. Essa distinção é extremamente

\footnotetext{
${ }^{12}$ Não tive oportunidade de presenciar nenhum desses casos. Uma médium contou-me, entretanto, um que dizia respeito a uma mulher "que hoje é médium e das mais equilibradas do centro. Ela ia ao Lar de Tereza. Depois ela contou que na época nem sabia aonde estava indo, para tomar passe na cabina. O Espírito incorporava e ficava horas falando. Eles (os médiuns) oravam, cantavam, conversavam com o Espírito.Hoje ela está muito bem e os Espíritos que a obsidiavam também melhoraram e provavelmente estão até aí trabalhando".
} 
importante para a identidade desse grupo religioso:

a doutrina será o que os espíritas fizerem dela. As pessoas que vêm buscar o passe são desequilibradas, são deseducadas na doutrina. Sabemos que aí fora há uma confusão tremenda do Espiritismo com Umbanda, ritual, fenômeno (.. .).

A incorporação na hora do passe sugere a situação da consulta umbandista que deve ser evitada a todo preço:

se damos o passe mediunizado, o paciente fica encorajado a perguntar isto ou aquilo. $O$ médium pode não estar seguro e dizer uma coisa que desequilibre o paciente. Pode dizer o que viu ou ouviu perto do paciente, ou dar conselhos para sua vida. Imaginem se for uma pessoa medrosa e o médium disser que viu um Espírito assim e assado, que transtorno pode causar a essa pessoa.

A consulta, na concepção espírita, ofende o livre-arbítrio do interessado, que, existindo, possui a qualidade peculiar de poder ser anulado ou retirado. Mesmo que o médium veja o futuro, não deve dizê-lo. O fato de o futuro do Espírito encarnado ser visível não nega o seu livre-arbítrio. É justamente o desconhecimento desse futuro que garante a margem estreita e limitada, mas decisiva, do exercício desse atributo. Cabe ao médium zelar pela integridade de sua religião, reafirmando a distinção entre passe e manifestação. Enfatiza-se o seu caráter ativo na mediação entre os mundos; mesmo transmitindo, ele controla e domina o seu corpo, dá ou não abertura aos Espíritos.

Apesar dessa visão, presenciei já no final da pesquisa um passe mediunizado. Era uma reunião na casa de "tia" Áurea, médium e colaboradora do Lar de Tereza, moradora do Leblon. Fui assistir a ela a convite de um dos médiuns da turma de desenvolvimento mediúnico. Lá se realizavam semanalmente uma reunião de estudo - leitura do evangelho, prece e passe - e uma reunião de mulheres que fazem trabalhos de costura para o bazar de caridade que ocorre todo Natal. Era a tarde de uma quarta-feira. Na sala, cheia de cadeiras, sentavam-se sobretudo mulheres, costurando alguma coisa, de uma faixa etária que ia dos 25 aos 60 anos. Havia um total de 50 pessoas, algumas das quais eram cooperadoras do Lar de Tereza. No quarto estava Joaquim, médium respeitado de todos no Lar de Tereza, que trabalha num centro da zona norte do Rio de Janeiro, e incorpora o Espírito Dr. Hermann. Apresentei-me à tia Áurea, que cinco minutos depois chegou à sala me chamando e explicando: "Ele é quem está chamando as pessoas." Com o que insinuava ela, uma vez que supostamente Joaquim desconhecia a minha presença lá, os seus elevados dons mediúnicos.

A reunião dividia-se em duas partes. Na primeira Joaquim chamava uma a uma as pessoas que lá se encontravam para uma entrevista sobre seus problemas. Embora o 
médium não estivesse incorporado, as pessoas referiam-se ao Dr. Hermann, que orientava a ordem de chamada das pessoas de acordo com a complexidade dos casos, ou em nome de quem se pedia silêncio:

Dr. Hermann está lá dentro. Com o barulho só estão prejudicando o trabalho de Joaquim. Em determinado momento pediu-se às pessoas que guardassem os trabalhos que faziam. Ia iniciar-se a segunda parte da sessão na qual Joaquim incorporaria o Dr. Hermann. Fecharam-se as cortinas para não haver queima de fluidos. O ambiente foi preparado, fezse uma prece, exortou-se as pessoas a servirem, a se engajarem nos trabalhos de caridade. Joaquim entrou na sala. Algumas mulheres agarravam suas mãos, beijavam-nas. Uma delas chorava copiosamente. Tia Áurea deu o braço a Joaquim, que, com duas inspirações fortes, passando a mão pelo rosto, incorporou o Dr. Hermann. A expressão facial do médium se alterou. Com os olhos cerrados começou a falar com forte sotaque alemão. Sua mobilidade corporal diminuiu. Os movimentos eram bruscos e tensos. O Dr. Hermann falou do amor ao próximo, da confiança que todos precisavam ter em si mesmos, da necessidade de trabalhar para tornar-se útil. E iniciou um circuito pela sala dando passes individuais. Seus passes eram imposição de mãos com toque. Com cada um conversava um pouco sobre os problemas que haviam contado ao médium Joaquim. Às vezes receitava um remédio: "Tome glifarex", ou: "Anote: Antabus". Ou dizia:

E a cabecinha, ponha no lugar. Reze, ore para manter a mente esclarecida.

Algumas pessoas que não puderam ser atendidas antes consultavam-se ali mesmo. Tia Áurea acompanhava-o, lembrando-lhe determinados casos. "Não deixe de tomar passe uma vez por semana." Informou a uma pessoa quem era seu mentor espiritual: "Eurípides". E assim percorreu toda a sala. Ao final, de frente para a platéia, com uma inspiração forte e passando novamente a mão pelo rosto, o médium voltou a ser Joaquim. Fez uma prece. Todos foram se retirando, cumprimentando Joaquim, que sabia os nomes de quase todos, e falava com alguns efusivamente.

Não é minha intenção discutir aqui a incorporação, que será examinada no próximo item. Chamo apenas atenção para a existência de um espaço reconhecido como legítimo para o passe mediunizado, que é desaconselhado aos médiuns de modo geral e não tem espaço nos rituais do centro. Sem dúvida, trata-se, no episódio relatado, de uma exceção a relação perfeitamente integrada entre o Dr. Hermann e Joaquim. Joaquim é Um médium conhecido, sua autoridade e qualidade são respeitadas. Outros não podem fazer o que ele pode sem riscos, em razão da sua superioridade. A qualificação de um médium pode assim 
sobrepor-se a normas de ordem geral que controlam o desenvolvimento da mediunidade. ${ }^{13}$ Afirmasse a hierarquia de posições e de autoridade característica desse sistema. Apenas aos superiores permitem-se certas coisas, fato que reforça e realça sua superioridade. Revela-se também, a partir desse episódio, a existência de duas faces complementares no Espiritismo, uma - mais formal, voltada para fora, para o público - que se realiza sobretudo no centro, e uma face mais informal que se realiza nas casas, nas redes de relações entre espíritas.

Tanto a recomendação do não-toque como a evitação da manifestação mediúnica no passe vêm ao encontro do ethos espírita de controle, discrição, sobriedade, expressando a exigência de controle do corpo por parte do médium. Retomarei a esse ponto no próximo item.

\section{c. A Manifestação Mediúnica}

Uma vez manifesta, é ao longo das sessões de desenvolvimento mediúnico que se definirá, dentre as possibilidades que esse sistema de crenças oferece, o tipo de mediunidade que uma pessoa detém, e na qual tenderá a se especializar.

As formas de experiência da mediunidade sofreram modificações desde a época de Kardec. Um tipo de mediunidade que desempenha um papel importante nas obras da codificação é a mediunidade de efeitos físicos, capaz de materializar Espíritos e objetos, de fazer objetos se moverem e se quebrarem. ${ }^{14} \mathrm{O}$ trabalho de efeitos físicos é hoje considerado "limitado", sendo poucos os médiuns portadores dessa forma de mediunidade.

Os espíritas explicam esse fato pela idéia de que,

acompanhando a evolução humana, a mediunidade sofreu também um processo evolutivo.

Na época de Kardec, a mediunidade de efeitos físicos era

parte de um plano traçado pela espiritualidade, o que importava era provar a nãointerferência humana nas manifestações dos Espíritos. Só depois que todos se conscientizaram (...) começaram os Espíritos a utilizar processos mais adiantados de intercâmbio (Apostila sobre Mediunidade).

\footnotetext{
${ }^{13}$ Seria extremamente interessante estudar esse processo de diferenciação entre os médiuns e perceber a trajetória particular dos médiuns de renome, mas essa questão extrapola os limites da pesquisa.

${ }^{14}$ Os Espíritos desencarnados, como vimos, agem sobre o fluido universal, moldando-o de acordo com a sua vontade. A materialização de objetos ou de Espíritos corresponde ao processo pelo qual os Espíritos, suas idéias ou "objetos" espirituais ganham invólucro corpóreo. Para tanto é necessário o concurso do médium que doa o seu fluido ou ectoplasma. As sessões de materialização eram, ao que tudo indica, extremamente comuns aqui no Brasil. Ver a esse respeito os relatos de Yvone Pereira in Recordações da Mediunidade. Assisti também no ICEB a um filme no qual se mostravam vários objetos materializados num centro espírita em Alagoas
} 
A mediunidade de efeitos físicos tem contudo seu lugar ainda hoje nas sessões de intervenção espiritual. ${ }^{15}$ No Lar de Tereza não se desenvolve esse tipo de mediunidade. As formas de mediunidade lá atualizadas são a psicografia e a mediunidade de incorporação ou psicofonia.

Para que uma manifestação mediúnica Ocorra é preciso que o médium dê passividade, expressão que indica ao mesmo tempo uma certa anulação do médium e a presença de seu livre-arbítrio e vontade na origem da manifestação. Segundo os espíritas:

nos diversos departamentos cerebrais existem núcleos de controle do Espírito.A epífise (glândula da mediunidade) é que favorece a passividade desses núcleos. Temos "tomadas mentais" e a epífise é a glândula que dirige essas tomadas. É ela que favorece a passividade maior ou menor. É através dessas tomadas que o Espírito comunicante faz suas pressões.

Na manifestação mediúnica,

o Espírito do médium se desloca, ou às vezes mesmo o perispírito, para que outras inserções tomem conta das células (Apostila sobre Mediunidade).

Há vários tipos de contato, o Espírito comunicante desliga algumas ligações do perispírito com o Espírito e liga a ele. Dependendo do "departamento cerebral atingido" não só varia a forma que a mediunidade toma, como o papel do médium na comunicação se altera, podendo ser ele consciente, semiconsciente, ou inconsciente.

Tanto a psicografia e a psicofonia, como a medi unidade consciente semiconsciente e inconsciente, serão discutidas a partir da descrição breve da sessão de desenvolvimento mediúnico.

\section{c.l A sessão de desenvolvimento mediúnico}

No Lar de Tereza as sessões de desenvolvimento mediúnico ocorriam semanalmente com revezamento de turnos. A dirigente do trabalho, como nas demais sessões mediúnicas, era a presidente do centro. As turmas variavam entre 18 a 12 médiuns entre homens e

\footnotetext{
${ }^{15}$ Tanto no Grupo Espírita André Luiz como no Templo Espírita Tupyara existem sessões de intervenção espiritual nas quais se realizam operações fluídicas. As operações fluídicas são operações feitas pelos Espíritos com o concurso dos médiuns no perispírito de pessoas doentes. Uma médium do André Luiz descreveu-me as sessões do seguinte modo: "A intervenção é o tratamento de doença nas pessoas. Tem 16 caminhas na sala. As pessoas se deitam e são cobertas por lençóis. Para cada doente é preciso dois médiuns. Há ainda dois que ficam na cabina para fornecer ectoplasma, que é necessário para os Espíritos transportarem os aparelhos da espiritualidade para operar. Naquela hora os doentes ficam cercados de Espíritos. Já houve até cura de câncer de intestino. É claro que tem que ter também o merecimento (... .)" Esse aspecto da medi unidade constitui-se numa vertente rica do Espiritismo, remetendo à questão da cura $\mathrm{e}$ ao campo maior da chamada medicina popular. Em virtude dos limites da pesquisa, não disponho, entretanto, de dados para discuti-la com mais detalhes.
} 
mulheres, de 25 a 60 anos. Durante o ano de 1980, as sessões realizavam-se na sala do andar térreo, e a distribuição do espaço era a seguinte:

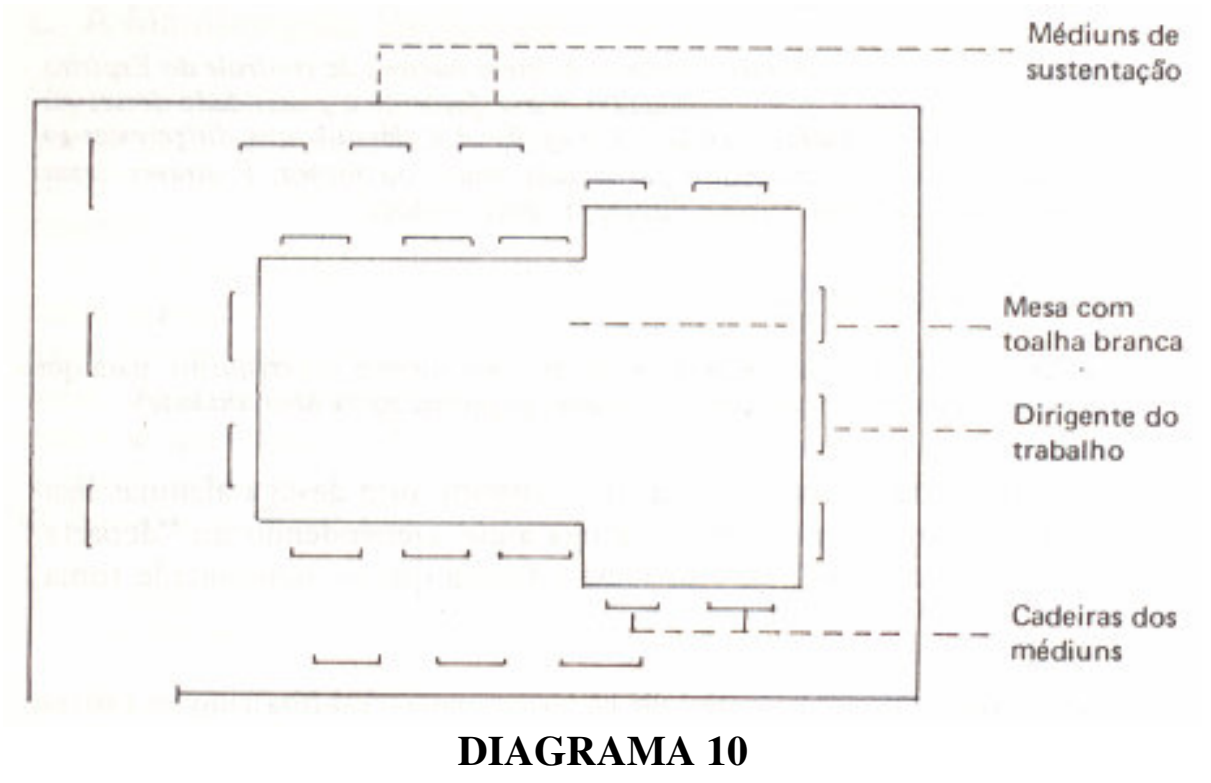

Em cada lugar da mesa há papel e lápis, no centro um copo cheio de lápis azuis de grafite preto e uma pilha de papel branco. Num canto sobre um móvel dispõe-se uma bandeja com copinhos de papel, com água que será fluidificada, i.e., na qual os Espíritos superiores depositarão ao longo da sessão bons fluidos. Uma sessão mediúnica é um ponto de encontro entre o Mundo Visível e o Mundo Invisível. Nela o invisível se toma visível através dos médiuns e de suas diferentes mediunidades. A oposição entre os dois mundos é momentaneamente transcendida. Em toda sessão mediúnica há uma distinção entre os médiuns que se sentam à mesa e os médiuns que permanecem na sustentação na dirigente quem designa os lugares dos médiuns. Os que ficam na sustentação são geralmente os iniciantes, ou os que não têm facilidade na recepção de Espíritos, embora não obrigatoriamente. Pode haver também um revezamento: quem ficou na sustentação numa sessão senta-se à mesa na seguinte e vice-versa. Os médiuns da mesa são os que receberão Espíritos através da psicografia e da psicofonia. Os da sustentação sentam se em cadeiras encostadas nas paredes. Estes últimos estão especialmente encarregados da sustentação do ambiente, i. e., da manutenção de um elevado "teor vibratório no recinto" através da emissão de pensamentos de paz e de amor. Eles permanecem a maior parte do tempo sentados, de olhos fechados, orando. Podem levantar-se de vez em quando para dar um passe nos outros médiuns ou para doutrinar (ver logo adiante) um Espírito. Alguns 
deles, bem como os médiuns da mesa, podem ser portadores de mediunidade visual. Através dessa faculdade terão visões do Plano Espiritual ali presente. Outros podem sofrer desdobramentos ao longo da sessão. O desdobramento é um afrouxamento do laço que une perispírito ao corpo. Através dele o Espírito abandona parcialmente o corpo e passeia, volitando, pelo Mundo Espiritual, O contato com o espiritual atualiza-se assim de diferentes maneiras, embora a sessão se destine explicitamente ao desenvolvimento da psicografia e da psicofonia.

Nos momentos que precedem o início da sessão, os médiuns permanecem em silêncio concentrando-se ou conversando baixinho. A sessão se inicia com a preparação do ambiente, seguida da fase da reunião destinada à manifestação mediúnica. Na penumbra, com as lâmpadas azuis acesas,

abre-se uma porta e estabelece-se livre trânsito entre os dois mundos.

Essa fase ritual compõe-se de três momentos distintos:

1. O primeiro deles destina-se ao exercício da psicografia. Os médiuns permanecem eretos com o lápis na mão pousada sobre o papel. Imóveis, Com os olhos cerrados, prontos para escrever. O transe inicia-se às vezes com uma ligeira alteração no ritmo respiratório: uma inspiração mais profunda, ou respirações mais rápidas. A mão começa a movimentarse.Escuta-se no silêncio o ruído do lápis deslizando no papel e o tique-taque do relógio de parede. A dirigente pode ou não fazer uma prece. Os médiuns de sustentação circulam' dando passes nos demais. Alguns escrevem muito, alguns pouco, outros nada. Passados uns 15 minutos, a dirigente orienta os médiuns para irem "se desligando":

Vamos pedindo aos Espíritos que terminem suas mensagens pelo respeito à hora que todos devemos ter.

Os médiuns soltam o lápis e voltam à postura ereta, com ambas as mãos pousadas com as palmas para baixo sobre a mesa. Mais tarde, na última fase da sessão, com as luzes acesas, a experiência dos médiuns, as mensagens recebidas são discutidas. Todas as mensagens psicografadas podem então ser lidas. Alguns passam-nas a limpo. A letra dos médiuns iniciantes é geralmente irregular. As mensagens psicografadas eram de dois tipos. Tratavase ou da comunicação de um Espírito superior como:

o pouco é muito para quem ama, e o muito nunca é demais para quem sabe se dar,

ou de testemunhos de Espíritos em estágio evolutivo mais ou menos equivalente ao dos médiuns, como o de uma mulher que desencarnara e vinha contar o quanto sofreu por não saber o que a esperava, diferentemente deles, espíritas, ou de um antigo colaborador do 
centro, desencarnado há um ano, que dizia que gostava muito de ouvi-los, de estar em sua companhia.

2. O segundo momento destina-se à psicofonia. A passagem de um momento para o outro é marcada por uma prece como a seguinte:

(...) Nem sempre os Espíritos que recebemos são de alta hierarquia. Estamos em treinamento. Coloquemo-nos nas mãos de nossos mentores. Não temamos.

No início dessa fase há sempre um certo "tumulto",vários médiuns incorporam Espíritos simultaneamente. Aos poucos vai-se restabelecendo uma certa ordem, Uma das recomendações de disciplina aos médiuns é a de que não dêem passividade a um Espírito enquanto houver outras manifestações ocorrendo. É comum, contudo, desenvolverem-se até três manifestações simultâneas. O desenvolvimento da manifestação requer a figura do doutrinador, que pode ser tanto um médium da sustentação como da mesa. O doutrinador sustenta o médium com vibrações e passes, aconselha-o a nada temer ou a despertar quando o transe está demorando demasiado, e, ao mesmo tempo, conversa com o Espírito, ajudando-o a expressar-se, contar o seu mal e a partir daí esclarecê-lo, fazer com que conheça um pouco os princípios da doutrina. Essa fase da sessão é na verdade um treinamento para a sessão de desobsessão que será discutida com mais detalhes logo adiante.

$\mathrm{Na}$ incorporação, o transe inicia-se de maneira mais marcada do que na psicografia, embora não necessariamente. E tem como que dois estágios. Um estágio inicial em que a cabeça pende de um lado para o outro, começa a rodar iniciando movimentos aparentemente descontrolados, tremedeiras, suspiros, gemidos e por vezes choro. Nos médiuns iniciantes é comum que o transe permaneça nesse estágio. E um segundo estágio em que ocorre a comunicação verbal do Espírito, que pode desenvolver-se mais ou menos.

Recebem-se por vezes Espíritos superiores, sendo, porém, mais comum a manifestação de Espíritos inferiores. Em uma das sessões a que assisti, por exemplo, um dos médiuns, com as mãos na cabeça que rodava, gemia de dor: "Ai, minha cabeça.Não agüento!..." A comunicação verbal do Espírito não ia mais além, apesar da fala do doutrinador. Em outra um médium, que permanecera todo o tempo de olhos cerrados, com a cabeça rolando suavemente, subitamente abriu os olhos, apontando o dedo para a dirigente da mesa que estava exatamente na sua frente:

Me disseram que você me ajudaria em minha vingança. Tenho um ódio muito grande. Vim aqui para você me ajudar.

A dirigente foi até ele, explicando-lhe que ele estava enganado, que lá não 
faziam isso. Iria ajudá-lo sim, mas a livrar-se do seu ódio. O espírito foi-se acalmando, repetiu com a dirigente um pai-nosso espírita, disse que até que ali ele se sentira bem, e foi-se.

Passados uns 15 ou 20 minutos, a dirigente novamente orienta os médiuns para irem se desligando, e com uma prece inicia-se o terceiro momento dessa fase ritual.

3. O encontro com o mentor. A incorporação do mentor não ocorre necessariamente. Pode haver simplesmente uma aproximação espiritual, um envolvimento do médium pelo mentor. Esse encontro caracteriza-se por uma espécie de relaxamento, um entorpecimento, da parte do médium. A sensação como os médiuns a descrevem é de paz, de tranqüilidade e de amor. Uma das médiuns descreveu-me do seguinte modo o contato com o mentor:

É um arrepio. Uma dormência do lado esquerdo das costas. Já sei que ele está presente. Quando ele incorpora, minha voz se modifica. Fica rouca. Às vezes nem sinto vontade de falar.

$\mathrm{Na}$ incorporação ou aproximação do mentor, a relação dominante na psicofonia, Espírito inferior/médium, inverte-se, passando a ser Espírito superior/médium. Muitos médiuns entregam-se nesse momento a uma crise de choro, que, mais do que um choro de dor ou remorso como ocorre na psicofonia, é um choro de alívio - o choro do Espírito encarnado que se percebe fraco e inferior diante da presença protetora de seu guia espiritual.Passados uns dez minutos, a dirigente recomenda mais uma vez aos médiuns que vão se desligando. Essa fase se encerra com uma prece de agradecimento aos amigos e protetores espirituais. Acendem-se as luzes. Os médiuns bebem água fluidificada.

Na última fase da sessão, com as luzes acesas e num clima que contrasta com o que predomina até então pela sua descontração, os médiuns discutem suas experiências medi únicas. A maneira pela qual cada médium registra a incorporação diverge bastante como me disse uma das médiuns:

não há duas mediunidades iguais, como não há duas personalidades iguais.

Um sente dormência nas mãos, outro leveza. Outro ainda, dores de cabeça, arrepios, enjôo etc. Analisam-se as mensagens recebidas, as dúvidas dos médiuns. Alguns Espíritos são identificados, seja pelos médiuns videntes presentes, seja por características repetidas em sucessivas comunicações que permitem a associação a algum parente ou conhecido desencarnado. O mais importante contudo é a identificação do grau evolutivo do Espírito. É preciso estar atento à mistificação, i.e., à tentativa de Espíritos inferiores de se fazerem passar por superiores. Essa identificação é feita geralmente pela linguagem utilizada pelo Espírito. A de um Espírito superior é concisa, séria, sem exageros. O médium que 
incorpora fala mantendo sempre o mesmo tom de voz. A de um Espírito inferior é raivosa, chorosa, vingativa, respondona. A voz do médium está impregnada de emoção. A de um Espírito mistificador peca pelo exagero, pela demonstração de vaidade, pelo rebuscamento e falta de concisão. Geralmente também o mentor não é identificado mesmo que seja visto. Sabe-se apenas se trata de um homem ou de uma mulher. Uma das médiuns disse-me o seguinte a respeito:

Nunca vi, não sei quem foi. O fato de não saber resguarda o médium. Por exemplo, se uma das minhas inferioridades fosse a vaidade e se o fato de eu saber quem foi aguçasse isso. Então os Espíritos não permitem.

Há aqui também exceções que, como sempre, realçam a superioridade do médium em questão. A presidente do centro, Betânia, conhece sua mentora, Idália, que foi sua irmã em uma encarnação no século XVII na Inglaterra. Era já então um Espírito superior que encarna em missão tendo desencarnado aos 12 anos de idade.

Descrevem-se as visões e os desdobramentos. Possíveis críticas ao comportamento dos médiuns podem ser feitas. Reconstrói-se, nessa fase, de múltiplas maneiras, a presença recente do Plano Espiritual no Plano Terreno, a sessão.

\section{c.2 A mediunidade consciente, semiconsciente e inconsciente}

Tanto na psicografia, como na psicofonia, dependendo do grau de deslocamento do Espírito do médium, ou na metáfora espírita da quantidade de tomadas desligadas e ligadas ao Espírito comunicante, os médiuns são classificados num continuum que vai do médium consciente ao médium inconsciente, passando pelo médium semiconsciente.

O médium consciente é também chamado de intuitivo. A intuição é, como vimos (capítulo II), pensada como uma forma sutil de comunicação espiritual, ou como lembranças que o Eu menor guarda de seu Eu maior (recordações de vidas pretéritas ou de idéias formuladas no estado de Espírito). Enquanto forma de comunicação espiritual sutil, o contato com o plano espiritual na intuição ocorre através do pensamento. O mesmo acontece na mediunidade consciente:

o Espírito comunicante atua sobre $i$ Espírito do médium com o qual se identifica, envolvendo-o em sua vibração. O médium transmite o que recebe.

O seu Eu menor não se paga, o médium se lembra de tudo o que fez. Seu papel é como o de um intérprete que traduz o pensamento que lhe apresentam.

Segundo os próprios espíritas, a mediunidade consciente traz o problema de se é consciente até que ponto não poderia o sujeito interferir? (Apostila sobre Mediunidade). 
Essa questão é intensamente vivida pelos médiuns. Nas sessões de desenvolvimento mediúnico, na parte final destinada à discussão da experiência dos médiuns, ela frequentemente vinha à tona. Certa vez por exemplo, augusto incorporou. O Espírito entretanto não chegou a falar, augusto tremia o tempo todo. Depois disse que lhe vieram à mente as palavras: "Vai bater, vai bater!" E sentira uma grande dor na cabeça. Ele achava que era um Espírito que sofrera um acidente. Betânia, a dirigente do trabalho, perguntoulhe se ele havia intuído alguma coisa. Augusto disse que sim, mas que achava que "era da sua cabeça". Betânia perguntou-lhe por que o seria. Augusto disse então que intuíra que era um avião monomotor que batera numa montanha recentemente. De outra vez, uma médium disse que na psicografia sentira grande eletricidade nas mãos, que tremeram o tempo todo. Betânia perguntou-lhe por que não tinha escrito. A resposta foi a mesma. Sônia achava que "era coisa da sua cabeça".

Augusto, que tinha se tornado espírita há cerca de um ano e meio e estava no desenvolvimento mediúnico há uns oito meses, disse-me o seguinte a esse respeito:

(...) No começo eu sentia muito medo do Animismo. Talvez por falta de embasamento doutrinário (...). Até pouco tempo atrás ainda tinha dúvidas se não era eu quem estava pensando. Porque há uma certa confusão. O que acontece é o seguinte: muitas das idéias que vêm à cabeça naquele momento se lhe afiguram conhecidas. E por quê? Porque o Espírito não se aproxima de nós só naquela hora. Muitas vezes ele está junto desde de manhã no Dia do Desenvolvimento Mediúnico. (...) Pode ser que as idéias venham à tona naquele momento mas são idéias que você já deve ter. Seja pelos sonhos ou por outra forma de comunicação qualquer. Dai a grande dificuldade. Você não sabe se as idéias são suas ou não... Aos pouquinhos vamos começando a sentir que não são nossas. Talvez eu ainda não tenha conseguido fazer a separação plena.

Acho que ainda falta mais para dizer que não tem nada de interferência. Isso aí Chito já disse. Por mais que você seja um médium desenvolvido, quanto mais desenvolvido menor a interferência. Agora o quanto, o percentual, eu não sei dizer. Por isso estou olhando só o degrau e não a escada, No médium iniciante deve ser grande porque você custa a dar passividade. Você ainda tem o seu Espírito muito preso e ele não faz aquele afastamento maior.

O Animismo, a interferência do Espírito do médium na comunicação espírita é antes que um empecilho, um dado, parte do desenvolvimento da mediunidade. O "será que é", "será que não é?" é, segundo os espíritas, uma dúvida que persegue o médium a vida inteira. Com o passar do tempo, o médium aprende a distinguir, mas o grau de "pureza" na transmissão de uma comunicação espiritual permanece sempre em alguma medida problemático. Retomarei a esse ponto adiante.

Há, contudo, alguns critérios "de bom senso" utilizados. Um deles é a incapacidade do médium para formular ou mesmo escrever o pensamento sugerido. É comum a menção de médiuns analfabetos que psicografam lindas mensagens, ou de médiuns que 
desconhecem determinadas línguas e falam ou escrevem nela quando mediunizados. Outro é o fato de o pensamento sugerido ser inesperado, contrariando idéias anteriores. Ou ainda:

Se eu pauto a minha vida de determinada maneira, se eu que sou uma pessoa assim recebo mensagens insensatas, é porque se trata de espíritos, porque eu não ia sentar-me aqui para escrever insensatez. Se são só coisas elogiosas. Pé atrás. Se é uma boa mensagem tanto pode ser de um Espírito elevado como da própria pessoa cujo Espírito naquele momento se expande. Por isso é que conhecemos muito de mediunidade, mas o que conhecemos é pouco. por isso devemos orar, pedir aos Espíritos que nos ajudem e ter sempre cautela, pois é melhor ter cuidado do que penar por excesso.

No médium semiconsciente o fluxo do pensamento e o impulso de escrever ou falar não são concatenados. Ele

escreve ao mesmo tempo que pensa ou não acompanha a rapidez do pensamento que lhe chega ao cérebro, e fala sem concatenar as idéias.

Por vezes, depois da manifestação, o médium esquece-se do que transmitiu,fica então

prova maior da interferência dos Espíritos, porque nós nunca nos esquecem. Os de nossas próprias idéias.

Na mediunidade inconsciente, o Espírito do médium desloca-se completamente, e o Espírito comunicante passa a controlar o corpo físico deste. Na psicografia, o impulso da mão que escreve é controlado pelo Espírito, na psicofonia as idéias transmitidas o são com as palavras do próprio Espírito comunicante. Em ambos os casos, o médium não se lembra, não tem consciência do que ocorre. Considerada como uma forma de mediunidade "mais espontânea", na mediunidade inconsciente é mais clara a distinção entre o médium, o Espírito encarnado que dá passividade, e o Espírito comunicante. Mesmo assim, a certeza de que se trata de uma comunicação mediúnica e não anímica é inatingível. $\mathrm{O}$ autor da manifestação pode ser o Eu maior do médium. Com o tempo, através do estudo da doutrina e da prática da medi unidade, o médium inconsciente pode tomar-se consciente, ou não. Ou pode ser consciente em algumas manifestações e inconsciente em outras.

No Lar de Tereza os médiuns eram, em sua maioria, conscientes. A presidente e principal médium era consciente e sua substituta Luísa era inconsciente.

Durante muito tempo, perguntei-me qual a forma de mediunidade mais valorizada entre os espíritas. A mediunidade consciente é, por um lado, vista como uma forma de mediunidade superior. Essa afirmação, contudo, nunca é feita explicitamente. Aproxima-se da intuição, que é também para os espíritas a mediunidade do futuro, quando todos os homens serão médiuns no sentido estrito do termo e se comunicarão diretamente com os Espíritos pelo pensamento. Embora a materialidade permaneça presente na mediunidade 
consciente, no próprio personagem do médium, ela ocupa nessa forma de comunicação um papel menor - o elemento mediador é sobretudo o pensamento, imaterial. Por outro lado, a mediunidade consciente traz em si, de maneira mais aguda, a questão da interferência do Espírito do médium, do Animismo. Entretanto, a capacidade de distinguir entre pensamento próprio e pensamento sugerido, ou a de mover-se cautelosa e ponderadamente diante dessas diferentes possibilidades é um dos fatores de confiabilidade do médium.

Na mediunidade inconsciente, a distinção médium/Espírito é mais evidente, pois, com o deslocamento do Espírito do médium, seu Eu menor apaga-se temporariamente. Mas, como vimos, a dúvida permanece. Essa forma de transmissão implica uma maior materialidade, pois o Espírito age diretamente sobre o corpo do médium. O médium não é capaz de lembrasse do que ocorreu. Contudo, o seu Espírito apenas se desloca, permanecendo próximo, dono de sua morada e, como tal:

Ele está sempre ali, tem obrigação de comandar, de policiar,

de disciplinar "os excessos" do Espírito comunicante. Em ambos os casos, o transe assume externamente a mesma aparência. O médium incorpora ou psicografa sentado e sentado deve permanecer, coibindo as manifestações e impulsos mais violentos do Espírito, tanto no linguajar como nos gestos. O médium deve "segurar o rojão".

Se a mediunidade consciente implica, sob certo ângulo, uma superioridade, o que pode ser percebido na idéia mesma de que, com o tempo de desenvolvimento e de estudo, a mediunidade inconsciente pode tornasse consciente; a mediunidade inconsciente é também extremamente valorizada. Por meio dela, o espiritual se manifesta de modo mais direto, em toda a sua força. Não só o Espírito se toma diretamente presente, como a anulação do Eu menor do médium libera o seu Eu maior - seu Espírito é nesse momento puro Espírito.

Cabe ressaltar em ambos os casos a questão da distinção pensamento próprio/pensamento sugerido, anímico/mediúnico. As representações espíritas acerca da mediunidade afirmam a impossibilidade de certeza nessa distinção, sem negar, contudo, sua possibilidade ideal. A distinção é impossível do ponto de vista humano. Instaura-se aparentemente uma "confusão" entre o visível e o invisível, o humano e o espiritual.

Mas, como vimos na discussão da obsessão, a impossibilidade dessa distinção deriva da necessária incompletude do livre-arbítrio humano e de seu permanente confronto com outros livres-arbítrios. Na comunicação espírita, quer na mediunidade consciente, quer na inconsciente, o livre- arbítrio do Eu menor ou do Eu maior funciona como o regulador do 
contato entre os dois mundos, impedindo a confusão entre espírito/homem, invisível/visível, garantido na manifestação mediúnica, no ponto de maior intensidade desse contato, a transitoriedade e ordenação da conjunção entre os dois mundos.

\section{c.3 A psicografia}

A psicografia é uma forma de mediunidade que ocupa um lugar importante no Espiritismo. ${ }^{16}$ Sua origem é simultânea à constituição dessa religião. Como relata Kardec (LE: 32-33), foram os Espíritos que indicaram a forma adequada de serem consultados:

adaptando-se um lápis a uma cesta, o lápis, posto sobre uma folha de papel, escrevia por si mesmo.

\section{Mais tarde}

reconheceu-se que a cesta nada mais era do que um apêndice da mão, e o médium, tomando diretamente o lápis, pôs-se a escrever por um impulso involuntário e quase febril (...).

Em estreita relação com o Estudo, a psicografia afirma num outro plano a valorização da palavra escrita. Como indiquei no capítulo III, a Verdade como o Espiritismo a concebe é revelada e essa revelação se dá gradualmente. Sua transmissão aos homens requer que estes estejam à sua altura, que eles também conheçam. Enfatizei então, no que se refere ao conhecimento, a complementaridade entre Espíritos e homens que abria o espaço do estudo, no qual se enfatiza uma certa autonomia do humano.A psicografia ocupa também um lugar importante nesse contexto. Nela, porém, diversamente do que ocorre no estudo, enfatiza-se a subordinação do humano ao espiritual. Como diz Yvone Pereira, médium psicógrafa, autora de várias obras mediúnicas:

Como médium jamais agimos por nossa livre iniciativa, senão permanentemente acionada pela vontade positiva das entidades amigas que nos dirigem, pois entendemos que o médium por si mesmo nada representa, e jamais deverá adotar a pretensão de realizar isto ou aquilo sem antes observar se é realmente influenciado pelas verdadeiras forças espirituais (Yvone Pereira, in Recordações da Mediunidade).

O médium é meio, canal, instrumento. É comum também que livros psicografados permaneçam muito tempo guardados, à espera da autorização do plano espiritual para publicação.

Ao contrário da produção dos intelectuais espíritas, produto de homens, as obras psicografadas são produtos espirituais. Através dessa forma de mediunidade, pela Codificação, a Verdade chegou aos homens. E é sobre ela que repousa hoje a inovação doutrinária no Espiritismo brasileiro.Processo este encabeçado pelas obras do Espírito

\footnotetext{
${ }^{16}$ Ver também, a respeito da psicografia, Soares, 1979.
} 
André Luiz recebido pelo médium Francisco Cândido Xavier, o Chico Xavier, como é chamado. ${ }^{17}$ Um dos intelectuais do ICEB atribuía a esse Espírito a maior dinamização no processo de conhecimento no Espiritismo:

Essa dinamização foi tão grande que eu me pergunto até se viesse por outro médium se os espíritas aceitariam. Talvez pusessem tudo, de lado dizendo: é tudo um bando de doido!

Como essa citação permite perceber, embora instrumento, e como tal diretamente subordinado ao Plano Espiritual, o lugar do médium e seu papel são essenciais. Essa instância humana ocupa lugar importante. A transmissão da Verdade requer não apenas que os homens de modo geral estejam à sua altura, como requer um médium capaz de efetivá-la,. como dizem os espíritas, um médium fidedigno, i.e., capaz de filtrar, sem a interferência do seu Espírito, a mensagem espiritual.

A discussão dessa questão, que remete à do estabelecimento dos critérios de Verdade no Espiritismo, ultrapassa os limites desta pesquisa. Ela seria por si só tema para outra pesquisa que exigiria, entre outras coisas, não só a leitura da vasta literatura espírita psicografada por médiuns brasileiros, especialmente Chico Xavier, como entrevistas detalhadas de histórias de vida com médiuns tidos como fidedignos. Chamo atenção, contudo, para três pontos.

O primeiro deles é o fato de que, muito embora o Espiritismo seja um Movimento Federativo, e as Federações correspondam a um esforço de unificação nessa religião, os médiuns fidedignos, i.e., aqueles dos quais parte o processo de inovação doutrinária, são geralmente médiuns de centros. Esse fato vem reafirmar a importância e autonomia dos centros nessa religião e indica também a necessidade de estudos mais aprofundados acerca da relação Federação/centros, e do lugar da Federação no Movimento Espírita.

O segundo ponto é o fato de que, para os espíritas, a fidedignidade, a melhor qualidade da mediunidade de um Espírito encarnado, é explicada pelo fato de já ter esse Espírito sido médium em outras encarnações, São pessoas que têm tarefas especiais a desempenhar. Se por si só, ao mediar os contatos entre Mundo Invisível e Mundo Visível, a mediunidade se reveste de um caráter sagrado, a mediunidade fidedigna o é duplamente, pois ela é no Eu menor um traço do Eu maior.

Finalmente, pelo que pude perceber com base no material de que disponho, há entre os médiuns uma hierarquia de sacralidade que se funda no reconhecimento dessa

\footnotetext{
${ }^{17}$ Em 1980, Chico Xavier tinha publicado 183 obras mediúnicas. Quatro estavam no prelo e 15 em fase final de preparação. Ele é natural de Pedro Leopoldo, Minas Gerais, onde aos 17 anos começou a freqüentar um centro. Transferiu-se posteriormente para Uberaba, onde trabalha como médium.
} 
fidedignidade. Essa hierarquia realiza-se em vários planos, indo desde o centro, redes de centros, Movimento Espírita da cidade, do Estado ou interestadual, até o Movimento Espírita Brasileiro como um todo. No centro estudado a médium mais fidedigna era a sua presidente, a hierarquia terrena fundava-se na hierarquia espiritual. O médium Joaquim (ver p. 108) era considerado excepcional por pessoas de diferentes centros. A médium psicógrafa Yvone Pereira é tida, no âmbito do Rio de Janeiro, como detentora: de uma mediunidade tão confiável quanto a de Chico Xavier. Este último é considerado unanimamente o maior médium brasileiro. A presidente do Lar de Tereza, quando estão em jogo questões importantes acerca da orientação do trabalho no centro, vai até Uberaba para receber através de Chico Xavier a mensagem de Bezerra de Menezes, o guia espiritual do centro. Certamente ela poderia recebê-la diretamente, mas como ela mesma me disse:

acho melhor assim, há mais segurança.

Por segurança entende-se o máximo possível de "filtragem" da mensagem do Plano Espiritual. Retoma-se à questão da distinção entre pensamento próprio/pensamento sugerido, a qual atravessa toda a experiência da mediunidade no Espiritismo.

A psicografia pode ser aproximada, no plano da mediunidade, ao estudo, e aponta, como tivemos a oportunidade de ver, para um aspecto importante desse sistema religioso que é o da inovação doutrinária. A incorporação por sua vez aproxima-se da caridade, e revela outros aspectos da experiência mediúnica. Discuti-la-ei através do ritual da desobsessão que focaliza essa forma de comunicação mediúnica.

\section{c. 4 A desobsessão}

A sessão de desobsessão é considerada "o ponto alto dentro do grupo espírita". Se todas as sessões são dirigidas pelo Plano Espiritual, a desobsessão o é totalmente, nela "mais do que nunca os médiuns assumem o papel de instrumentos". Ela corresponde no centro pesquisado ao máximo de intensidade do contato entre o Mundo Visível e o Mundo Invisível. Os componentes da reunião não devem ultrapassar o número de 14, as visitas devem ser evitadas, quando aceitas não devem exceder três ou quatro reuniões. ${ }^{18}$ Nessa sessão, os médiuns entram em contato com

toda sorte de Espíritos sofredores: suicidas, homicidas, malfeitores, inteligências galhofeiras, vampirizadoras.

\footnotetext{
${ }^{18}$ A primeira norma não é rígida. Na primeira reunião de desobsessão a que assisti havia, excluindo-se a minha presença, 17 médiuns. Esse excesso foi claramente visto como desaconselhável, mas a reunião foi realizada assim mesmo, pois "os Espíritos nos permitem aquela margem de erros". Assisti a quatro reuniões de desobsessão.
} 
Esses Espíritos serão doutrinados. Procurar-se-á ensinar-lhes alguns princípios da doutrina e conduzi-los ao arrependimento. A desobsessão é um "trabalho de Socorro aos sofredores". Ela é feita em nome dos obsidiados que procuram o centro. Seu alvo são os Espíritos obsessores.

Por causa da importância do trabalho, a responsabilidade do médium é também maior. Os médiuns que dele participam são médiuns já desenvolvidos, que devem ter muita autoridade moral, e firmeza na conduta. O preparo ritual deve ser respeitado com todo o rigor. No dia do trabalho, ou mesmo alguns dias antes, o médium é objeto de uma aproximação espiritual, que promove a integração psíquica necessária para a ocorrência da manifestação. Segundo os espíritas esse processo ocorre da seguinte maneira: os mentores designam um Espírito para ser socorrido; para que esse Espírito possa comunicar-se mais livremente é preciso que ele estabeleça com o médium que o incorporará uma ligação fluídica com alguma antecedência; esse Espírito é posto pelos mentores desde a véspera junto à aura do médium para que haja integração psíquica. Ora, como esse Espírito é um sofredor, está em desequilíbrio;

se entra em ligação fluídica com o médium, transmite naturalmente sensações desagradáveis.

O médium pode ser vítima de dores de cabeça, náuseas, vômitos, mal-estar, os quais o acompanharão até o momento da manifestação. É o "ônus do trabalho mediúnico". O médium deve registrar a presença do Espírito mas não se deixar envolver por suas vibrações. Deve em contrapartida vibrar positivamente, envolvendo o Espírito em vibrações benéficas.

A manifestação de um Espírito superior pela psicografia ou pela psicofonia requer também a integração psíquica e, segundo os espíritas,

de acordo com a envergadura moral do trabalho a ser realizado pelo Espírito junto ao médium, há espíritos que levam anos em contato fluídico com o médium, preparando a ligação entre ambos, para que a mensagem a ser transmitida possa ser autêntica, perfeitamente filtrada pelo médium (Apostila sobre Mediunidade).

É o caso dos médiuns famosos como Zé Arigó/Dr. Fritz, Chico Xavier/André Luiz e Emmanuel. Espírito e médium relacionam-se assim de maneira mais ou menos duradoura. Na desobsessão essa relação é temporária.

A desobsessão realizava-se no aposento aos fundos do segundo andar do centro. Enquanto Betânia (a dirigente dos trabalhos/presidente do centro) e Luíza (sua substituta) 
o arrumavam, a preparação do ambiente iniciava-se já na sala central "para não perturbar o ambiente lá dentro". Meia hora ou 15 minutos antes do início da sessão os médiuns liam e discutiam o livro Libertação de André Luiz (psicografado por Chico Xavier). Betânia chamava-os quando a sala estava pronta. A maioria dos médiuns sentava-se à mesa, um ou dois médiuns permaneciam na sustentação. A disposição do espaço era a seguinte:

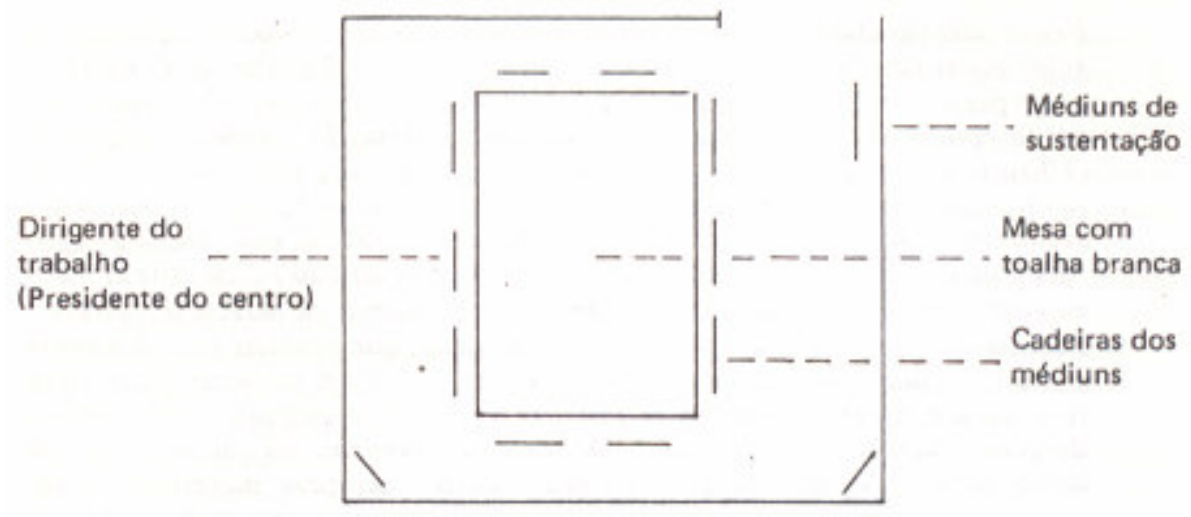

Diagrama 11

A sessão propriamente dita inicia-se com duas breves leituras do Evangelho segundo o Espiritismo e do Livro dos Espíritos, sem comentários. Finda a leitura, apagam-se as luzes, acendem-se as lâmpadas azuis e a dirigente do trabalho, Betânia, faz uma prece:

Sabemos que somos imperfeitos. mas neste momento deixemos as nossas imperfeições de lado e concentremos o nosso pensamento no amor, enviemos vibrações de amor ao nosso próximo.

A prece prossegue pedindo a Jesus e amigos espirituais que acompanhem o trabalho.

Embora a sessão de desobsessão contenha preces, ela opõe-se num plano à de irradiação (ver p. 100). Nesta última, o pensamento e vibrações devem dirigir-se a Jesus. Enfatiza-se a imperfeição dos médiuns e a sessão não se destina prioritariamente à incorporação de Espíritos. Através da prece, são os homens que se elevam até os Espíritos. $\mathrm{Na}$ desobsessão, as vibrações são dirigidas ao próximo, deixa-se de lado a imperfeição, a sessão destina-se à incorporação. Enfatiza-se nela a superioridade e autoridade moral dos médiuns diante dos Espíritos inferiores trazidos até eles pelos Espíritos superiores. Na desobsessão os médiuns, incorporando e doutrinando Espíritos desencarnados inferiores, tomam parte ativa no Mundo Invisível, beneficiando indiretamente os homens. Na irradiação , os Espíritos superiores, chamados a alocar entre os humanos necessitados os recursos fluídicos que os médiuns emitem através da prece, participam ativamente do Mundo Visível. Ambas as sessões afirmam de maneira inversa a complementaridade existente entre os dois mundos. 
Finda a prece, inicia-se a fase de incorporação e doutrinação dos

Espíritos.Transcrevo do caderno de campo parte de uma das sessões que presenciei.

Fez-se silêncio durante alguns minutos. Pensei que era tempo de os amigos e guias espirituais trazerem até ali os Espíritos. Betânia levantou-se e começou a dar passes em Sílvia, que estava à sua direita. Em pouco tempo Sílvia começou a contorcer-se. gemendo. Suas maos foram tomando o aspecto de garras.

O Espírito começou a rugir. Betânia, continuando os passes, evocava: "Forças Benditas da Paz, correntes amigas do Bem!" Dizia ao Espírito: "Meu filho, acalme esse ódio, abrande-o, ele o envenena etc." Sílvia continuava a rugir.

Aos poucos acalmou-se. Com um tremor a médium saiu do transe. Pôs as mãos no rosto "gritando" baixinho: "Da Betânia, que horror, eu parecia um bicho!" Betânia disse-lhe que se acalmasse, que esquecesse, que pensasse no seu mentor e pedisse a sua aproximação. Betânia começou a dar um passe em Bruno, que recebeu um Espírito com muita falta de ar e com a garganta seca. Betânia dirigiu-se então a Luísa, dando-lhe passes.

Luísa permaneceu quieta, fez-se um longo silêncio. O silêncio prolongava-se. Luísa balançava suavemente a cabeça, quando Bruno novamente incorporou. Betânia dirigiu-se a ele. Quase ao mesmo tempo Luísa incorporou.

Maria dirigiu-se até ela. Concentrei minha atenção em Luísa. O Espírito que recebera afastara um pouco a cadeira da mesa, como se quisesse levantar-se. Pusera os dois braços apoiados nas pernas abertas, numa atitude de briga, e dizia com a voz forte e irritada: "Eu não sei o que é que eu vim fazer aqui Eu não pedi para vir aqui. Eu não estou a fim de ficar aqui Já estou ficando nervoso e vocês não sabem do que eu sou capaz quando fico nervoso." Nesse meio-tempo incorporaram outros dois Espíritos que também lá estavam a contragosto. Em alguns momentos o Espírito de Luísa falava com o de Sílvia: "É, vamos embora, é melhor nós irmos embora mesmo." E dizia para Maria, que tentava doutriná-lo: "Quer parar com essa conversa! Aqui com vocês é sempre essa conversa. Essa conversa velha. Eu não estou a fim de conversa. "Maria tentava em vão imprimir outro rumo ao diálogo, dizendo que se ele ali estava era para ser ajudado etc. Espírito: "Chega de conversa, Ih! Isso agora virou confessionário.

Cadê o padre?"Maria: "Nós aqui não temos padres, mas somos seus amigos" Espírito: "E quem está querendo amigos? Olhe, eu já estou ficando nervoso. Eu quero ir embora. Deixem-me ir embora. "Sílvia saiu do transe e Bruno também. Os Espíritos que receberam haviam aceitado orar e tinham ido embora. Ainda atrás de Bruno, Betânia dizia em voz alta: "Pensamento firme em Jesus, amigos! "Pensamento em Jesus". E entoou uma oração. Maria começou a orar junto com ela com a voz igualmente alta. Betânia dirigiu-se para Luísa. Interpôs-se entre ela e Maria e começou a falar em voz alta: "Vós saibais que se aqui estais é porque estais em um momento decisivo, momento pelo qual todos já passamos. É chegada a hora em que é preciso olhar para trás, olhar para a frente e escolher. Este é um momento decisivo em que todos vós tendes a oportunidade de escolher. "E assim continuou durante algum tempo. O Espírito pouco a pouco foi sucumbindo diante de sua firmeza, de sua autoridade, parando de repetir que não queria conversa. Betânia perguntava-lhe, dirigindo-se a ele agora na terceira pessoa, por que ele não se permitia um choro: "Deixe o remorso rolar em suas lágrimas. "O Espírito dizia: "Não, eu não quero, não faça isso comigo. Olhe o que você está fazendo comigo" Betânia: "Chore, meu filho, Deixe que sua alma se lave com o pranto". Espírito: "Não faça isso comigo. Eu não quero.” E o Espírito irrompeu num pranto convulsivo. Betânia continuou a falar-lhe. Fez com que o Espírito repetisse com ela uma prece. Ele repetia num fio de voz entre lágrimas. Quando terminou, Betânia disse-lhe que olhasse o passado. Espírito: "Eu não posso, eu não posso, com que cara eu vou olhar para eles. Os meus amigos, esses não vão mais querer me olhar. E os outros, ah! os outros, esses eu não vou poder olhar!" Betânia: "Meu filho, os outros são amigos, eles sabem perdoar." Espírito: "Deixe-me falar. Eu não posso olhá-las. Eu não tenho aonde ir. Como vou olhá-los? Acho que vou ficar aqui no meu canto." Betânia: "Grande idéia você teve, meu filho. Fique aqui. Enquanto aqui estiver em nossa casa, pode estar certo de que estará tranqüilo, de que oraremos por ti. Enquanto isso, meu filho, 
repouse. Os amigos espirituais vão fazê-lo adormecer". Luísa sacudiu-se e saiu do transe. Assoou o nariz com um lenço, passou a mão pelo rosto, e permaneceu com a cabeça ligeiramente abaixada, pousada sobre as mãos.

Betânia disse então que era hora de orar para encerrar o trabalho. Fez uma prece agradecendo a Jesus e aos Espíritos superiores o auxílio. Todos os médiuns tomaram passes individuais. Distribuiu-se água fluidificada. Acenderam-se as luzes. Betânia olhou-me atentamente e perguntou-me se eu estava me sentindo bem. Disse-lhe que sim. Luísa comentou ainda Um pouco abatida, que sentira muita emoção. Roberto tivera um desdobramento, vira paisagens do Mundo Invisível Betânia contou um sonho que tivera naquela noite com Um orfanato. Iniciou-se uma conversa sobre os trabalhos do centro. Estava terminada a sessão. Pouco a pouco todos foram se retirando, com a recomendação de que, ao sair dali, nada deviam comentar sobre a sessão: "A palavra estabelece uma ligação mental entre quem fala e o objeto do comentário. Pode reviver a chaga mental do desencarnado. A obra de desobsessão é de libertação das trevas. Não haverá libertação sem o esquecimento do mal."

Não há, ao menos explicitamente, identificação dos Espíritos que se manifestam. Embora, como me disse Luísa,

algumas vezes as características do Espírito são as mesmas da pessoa que atendemos no atendimento fraterno. Mas não comentamos nada.

A doutrinação do obsessor, que pode regenerar-se a partir dela, beneficia indiretamente o obsidiado.

A representação espírita da pessoa, como vimos, afirma simultaneamente que, como Espírito encarnado, o homem tem uma essência, uma individualidade, uma história particular, algo só seu e que o distingue dos demais; e que, assim sendo, ele existe em permanente contato com os Espíritos que com ele se comunicam inspirando-lhe pensamentos e ações. A justaposição dessas proposições é possível dado o caráter incompleto do livre-arbítrio e individualidade humanos. Ela não deixa, contudo, de constituir-se para os espíritas numa tensão que permeia toda a experiência da mediunidade.

O livre-arbítrio, atributo essencial do Espírito, tem nesse sistema um caráter elástico: existindo como criação divina ele é maior ou menor de acordo com a evolução do Espírito e pode ser retirado ou aniquilado por sua própria atividade. Existem assim no mundo livres-arbítrios mais ou menos plenos, e a comunicação espiritual, ao contatar Espíritos encarnados e desencarnados, é sempre um confronto de livres-arbítrios. O livre arbítrio, de um Espírito é sempre naturalmente limitado pelo determinismo divino, e sempre potencialmente limitado por outro livre-arbítrio mais poderoso que o seu. O determinismo, como vimos, é o efeito da limitação do livre-arbítrio de um Espírito por Deus ou pelo livre-arbítrio mais poderoso de outro Espírito.

A obsessão é a possibilidade última da limitação de um livre-arbítrio 
por outro. Mesmo originando-se no livre-arbítrio do homem, ela corresponde ao aniquilamento desse atributo. $\mathrm{O}$ obsidiado torna-se totalmente incapaz de distinguir entre pensamento próprio e pensamento sugerido. O pensamento sugerido torna-se seu, e seu pensamento se anula. Ele torna-se, como vimos, um médium às avessas. Obsidiado e obsessor apresentam-se confundidos num mesmo personagem. Instaura-se uma confusão entre o visível e o invisível. O homem torna-se só matéria, e o Espírito desencarnado obtém um corpo ilegitimamente: esse corpo é de outrem e é transformado num fim em si mesmo. A obsessão é conjunção indevida entre os dois mundos, ela é antimediunidade e antiencarnação, congelamento da

Evolução, ameaça de fim da condição humana.

No ritual da desobsessão, essa ameaça é momentânea e repetidamente rechaçada. A desobsessão, como o nome o indica, inverte o processo da obsessão. Nesta última um Espírito inferior e um Espírito encarnado estabelecem um contato que termina numa identificação: o Espírito inferior domina o médium misturando-se com ele. $\mathrm{Na}$ desobsessão, um Espírito encarnado (médium) e um Espírito inferior relacionam-se também - e a obsessão é sempre um perigo que ameaça o médium. Nela, porém, a relação que culmina na incorporação é ritualmente controlada de modo a garantir a disjunção dos mundos, a ordem do universo.

O transe da desobsessão coloca em cena quatro tipos: o Espírito superior, o médium de incorporação, o doutrinador/médium de sustentação, e o Espírito inferior. No jogo que se estabelece entre esses personagens, a tensão entre as imagens de homem como guardando sua individualidade e como joguete de forças ocultas a ele se expressa e se resolve momentaneamente num equilíbrio instável.

A doutrinação é um diálogo com o Espírito inferior que incorporou em um médium. Nele, o doutrinador procura ensinar ao Espírito os princípios da doutrina e conduzi-lo ao arrependimento. O doutrinador tem um duplo papel. Cabe a ele sustentar o médium de incorporação com passes, preces e vibrações positivas. E cabe a ele, pela sua fala e autoridade moral, conduzir o Espírito inferior ao arrependimento. Assim, de um lado, com a sustentação do médium, ele é o canal de comunicação com os Espíritos superiores. E, de outro lado, com a doutrinação propriamente dita, ele expressa a valorização do verbal e da consciência como os espíritas a concebem. Mais precisamente, a conexão doutrinador/Espíritos superiores é expressão de uma limitação legítima do livre-arbítrio humano, de uma limitação que, afirmando.o como incompleto, não impede o seu exercício, sendo mesmo a sua garantia. 
$\mathrm{O}$ médium de incorporação toma o lugar do obsidiado, representa-o simbolicamente. $\mathrm{Na}$ incorporação expressa-se com clareza o sentido que a mediunidade ostensiva tem para os espíritas. Ela é uma tarefa, uma provação, um testemunho. Se o médium é então superior ao Espírito que se manifesta, a sua mediunidade é por si só uma lembrança de sua imperfeição e relativa inferioridade, de sua humanidade em suma. Nela, a individualidade do médium parece apagar-se. Mas, Como já vimos se o médium for consciente, seu Eu menor permanece presente, e, mesmo passivo, controla o Espírito manifestante. Se o médium for inconsciente, apenas seu Eu menor se apaga, seu Eu maior se liberta.

A mediunidade de incorporação é nesse sentido uma prova inversa à encarnação. A encarnação afIrma o domínio do Espírito sobre a matéria no próprio fato de que o Espírito se submete ã matéria, ao corpo, para transcendê-la. A mediunidade de incorporação afirma o domínio do Espírito sobre a matéria pelo deslocamento do Espírito do médium de seu corpo, e pela "encarnação" temporária de um outro Espírito. Como a encarnação, a mediunidade é provação, testemunho. Em ambos os casos está em jogo a garantia do exercício limitado mas decisivo do livre-arbítrio humano, condição da evolução e do progresso. Em ambos os casos esse exercício se dá num confronto do Espírito com a matéria. A maneira pela qual esse confronto se dá inverte-se, porém, de um caso para o outro.

Ela é também uma antiobsessão, pois o transe é um resgate do médium que o fortalece, reencenando, de maneira invertida, o drama do obsidiado:

o médium empresta ao Espírito condições para que ele se esclareça (Apostila de Mediunidade).

O Espírito do médium permanece presente, controlando o seu corpo e indiretamente o Espírito comunicante. $\mathrm{O}$ transe afirma não o domínio do Espírito inferior sobre o Espírito encarnado mas a vitória do livre-arbítrio do médium, e por extensão do livre-arbítrio humano, sobre o livre-arbítrio do Espírito inferior desencarnado.

O corpo, como o Espiritismo o concebe, é sobretudo matéria, é da ordem do físico, do orgânico, oposto ao espiritual. Se ele é um instrumento indispensável de ação do Espírito encarnado, ele é ao mesmo tempo um entrave, numa prisão da qual o Espírito naturalmente anseia por fugir. ${ }^{19}$ corpo como matéria é para o homem o símbolo vivo de

\footnotetext{
${ }^{19} \mathrm{Na}$ idéia do corpo como prisão, na desvalorização da matéria e valorização do espiritual há como que um apelo ao suicídio. Talvez este seja um dos motivos pelo qual o suicídio - presente nas sessões através da
} 
sua imperfeição, de sua provação, da encarnação em suma. Como tal, ele é tentação no sentido em que a Encarnação é a atualização do livre-arbítrio, da escolha reafirmada a todo momento entre o Bem ou o Mal. O corpo é fonte de vícios - tabagismo, alcoolismo, uso de drogas,comportamento sexual desregrado etc. - que devem ser combatidos. O corpo, enquanto matéria, existe para ser transcendido. O corpo tal como ele se expressa no transe, o corpo social no sentido de Mary Douglas (Douglas,1970), está marcado por essas concepções. No momento do transe, não só o Espírito do médium torna-se Eu maior como seu corpo, dissociado de seu dono, torna-se puro corpo, i.e., matéria que será temporariamente animada por um outro Espírito. O Espírito do médium deve nesse momento afirmar a relação permanente que existe na pessoa entre Espírito e corpo, a transcendência do corpo pelo Espírito. Não importa qual seja a vontade do Espírito comunicante, o corpo deve ser controlado, seus impulsos regrados, domados. Ele permanece sentado, obediente ao comando de seu verdadeiro dono.

O controle do corpo no transe coaduna-se com o ethos espírita de discrição, sobriedade, disciplina. Nesse momento, contudo, a indiscrição, o excesso, a indisciplina são explicitamente sugeridos através do Espírito inferior que, tendo tomado emprestado o corpo do médium, esforça-se por fazer dele a sua vontade. A disciplina do corpo por parte do médium é o resultado de um confronto de vontades distintas pelo domínio de um mesmo corpo. Extremamente valorizada, ela expressa a vitória do médium, do Espírito Encarnado, ela afirma a individualidade e o livre-arbítrio humanos.

No que se refere ao Espírito inferior que se manifesta, ele foi, segundo os espíritas, e como a sessão transcrita permite perceber, muitas vezes levado até o centro contra a sua vontade pelos Espíritos superiores, fato que certamente enfraquece seu livre-arbítrio. Segundo uma médium, porém, os Espíritos superiores observam todo o tempo os inferiores, atentos ao momento indicado para sua regeneração, e levam-nos à sessão baseados em rápidos pensamentos, desejos, pequenos sinais de um desejo de recuperação, "um Iam pejo de possibilidade que eles não querem admitir".

Assim, se o Espírito incorpora contra sua vontade, a doutrinação apela decisivamente para essa vontade e esse livre-arbítrio.

manifestação de Espíritos suicidas e tema constante de matérias dos jornais espíritas -, visto como exercício indevido e excessivo do livre-arbítrio, é veementemente condenado. O suicida, segundo os espíritas, é vítima da grande ilusão de poder escapar a canoa e à lei da reencarnação. $\mathrm{O}$ aborto, o suicídio, o assassinato, a pena de morte igualam-se no sentido em que são todos considerados como usos excessivos do livre-arbítrio e negações da ordem cósmica. 
A incorporação/doutrinação do Espírito obsessor na de sob sessão encena um momento crucial da trajetória evolutiva do Espírito, um ponto central nesse sistema de crenças - o momento do arrependimento cósmico do Espírito, O momento no qual o livrearbítrio do Espírito se exerce em sua plenitude, em que o Espírito opta por continuar no Mal ou por regenerar-se:

No Plano Espiritual, o Espírito está muito mais desperto, não recebe tanta solicitação exterior, vê-se frente a frente com a sua realidade. (...) Se a desobsessão for bem-sucedida, aquele momento representará, quem sabe?, o início, o marco de um período de regeneração dentro da aceitação das Leis Divinas.(...) O Espírito sofre violentamente a dor do remorso, da consciência ferida (Apostila sobre Mediunidade).

Como Eu maior, no estado de desencarnado, o Espírito se arrepende, numa vitória do Bem. Sua recuperação se inicia através das provações de sucessivas Encarnações. Seu livrearbítrio, que o conduziu ao Mal, afirma-se novamente na explosão de culpa e remorso. Em suas futuras vidas encarnadas, como Eu menor, esse livre arbítrio e essa individualidade se afirmarão em suas provações.

O transe da desobsessão é assim um confronto em vários planos. Ele reencena o drama do obsidiado, que se confunde com um Espírito desencarnado até a perda de sua vontade e livre-arbítrio, invertendo esse processo. O Espírito comunicante, obsessor, é conduzido até o arrependimento - que é afirmação de seu livre-arbítrio - pela dupla ação do médium de incorporação e do doutrinador. No personagem do doutrinado renfatiza-se a consciência e individualidade humanas. De maneira diversa, o médium de incorporação afirma também a individualidade de seu Espírito e o domínio deste sobre o seu corpo. Em ambos os casos, contudo, essa individualidade é, por definição, incompleta, se exerce num mundo hierarquicamente concebido e depende da conexão com os Espíritos superiores.

No transe da desobsessão, o aniquilamento do livre-arbítrio humano (a possessão) é, pelos mesmos mecanismos, sugerido como possibilidade e rechaçado. A tensão, que permeia as representações espíritas da mediunidade entre as imagens distintas do homem como guardando sua individualidade e livre-arbítrio e como instrumento passivo dos Espíritos, se resolve temporariamente. A condição humana, e com ela a ordem do universo, afirma-se numa vitória momentânea e precária. 


\section{CONCLUSÕES}

Pretendi neste livro entender o Espiritismo a partir de sua análise enquanto um sistema religioso. Procurei apreender as representações, categorias e práticas que o constituem, os valores que nele se expressam, a noção de pessoa que aí se forja. A literatura sociológica existente sobre essa religião caracteriza-a geralmente a partir de uma análise externa no sentido em que não leva em conta, de maneira sistemática, o discurso do informante sobre si mesmo. Como vimos no capítulo I, configura-se como relevante nessa literatura a questão das relações entre o Espiritismo e as demais religiões mediúnicas. Nestas conclusões desenvolvo, na perspectiva adotada neste trabalho - a de uma análise interna ao Espiritismo -, algumas reflexões sobre essa questão.

O sistema ritual espírita compõe-se, como vimos, de três pólos: o estudo, a caridade e a mediunidade. No estudo expressa-se a ênfase intelectual característica dessa religião, a valorização da investigação racional, da pesquisa experimental. Na caridade enfatiza-se o seu caráter cristão, a vivência do amor ao próximo segundo os ensinamentos de Jesus reinterpretados à luz do Espiritismo. Na mediunidade afirma-se a relação entre homens e Espíritos. Todos esses pólos estão, como vimos, evidentemente inter-relacionados: a mediunidade comporta também a caridade e o estudo;e o estudo e a caridade, como formas de estabelecimento de relação com o espiritual, são também mediunidade. Mas a mediunidade, entendida em sua acepção mais abrangente como comunicação entre homens e Espíritos, é a categoria englobante de todo esse sistema ritual (ver o capítulo III). E, em sua acepção mais estrita, entendida como recepção de Espíritos, a mediunidade constitui-se na experiência central dessa religião (ver os capítulos III e IV). A importância da medi unidade e da experiência do transe no Espiritismo aproximam-no, na sociedade brasileira, das demais religiões mediúnicas.

Como vimos no discurso dos grupos pesquisados (ver, por exemplo, discussão do passe), a questão da relação entre Espiritismo e demais religiões mediúnicas, em especial a Umbanda, era sempre problematizada. Em um plano, a questão dessa relação impõe-se aos espíritas de fora para dentro: ela aparece, como veremos, periodicamente nos jornais cariocas. Em outro plano, ela surge na vivência mesma dos grupos estudados. Em ambos os planos, as respostas produzidas, bastante distintas entre si, estão preocupadas em marcar diferenças. 
Ao longo de toda a pesquisa o termo Espiritismo aparecia constantemente nos jornais associado a crimes. Nesses casos, Espiritismo, Umbanda e Candomblé são reunidos sob um mesmo rótulo estigmatizante. ${ }^{1}$ Os espíritas respondem geralmente não rejeitando o estigma em si, mas sobretudo excluindo-se dele, como a carta que transcrevo a seguir o evidencia:

O Jornal do Brasil de 18 e 19 de outubro publicou duas reportagens sob os títulos "Multidão mata a pau e foice fazendeiro e peão acusados do assassínio de menino" e "Inquérito vai apurar chacina causada pela morte do menino". Em ambas há deturpação evidente do que é o Espiritismo, precisando de reparos junto aos leitores.

Em princípio queremos deixar bem claro que o Espiritismo não tem culto material, não adota ritual, oferendas, sacrifícios de animais e muito menos de seres humanos para abrir caminhos ou resolver assuntos de ordem material, segundo informa a reportagem do dia 18. É nosso dever esclarecer que, para a doutrina espírita, o verdadeiro culto é o interior. (...) Por essa razão ele não adota de forma alguma denominações como pai-de-santo, cambono e outras coisas no gênero.

O Espiritismo, é bom que também se saiba, não tem nenhum vínculo com o africanismo ou outros cultos fetichistas, não sendo portanto fruto de qualquer forma de sincretismo religioso. (...) Um centro espírita jamais poderia ter sido palco de práticas exóticas e de crime nefando. Nos centros espíritas que se orientam pela doutrina codificada por Allan Kardec há, sobretudo, uma preocupação muito grande com a educação moral da criança. Tanto assim que ela, nesses centros, recebe orientação espiritual calcada na mais pura moral cristã.

Por outro lado, há um só Espiritismo, o que foi codificado por Allan Kardec. Não há por isso mesmo diferentes categorias, ou seja: nem "alto", nem "baixo" Espiritismo, tampouco de "linha branca" segundo a nota do dia 19 no Jornal do Brasil Também não há por conseqüência nenhuma seita oriunda do Espiritismo inovando-o quanto à sua doutrina.

Outro equívoco da reportagem é afirmar a existência do "Kardecismo ou Espiritismo de mesa". A doutrina é dos Espíritos não é de Allan Kardec(...).

Vamos lembrar a conclusão final inserida na obra $O$ Espiritismo e as Doutrinas Espiritualistas, do conhecido escritor espírita Deolindo Amorim: "0 Espiritismo é uma doutrina que se basta a si mesma, sem empréstimos nem acréscimos artificiais." Isso é dito após o término de sua proposição de que nenhuma religião poderia absorver o Espiritismo ou confundi-lo, a despeito da existência de aspectos comuns, porque suas concepções basilares, tendo conseqüências científicas, filosóficas e religiosas, não permitem adaptações e concessões arbitrárias.

Por tudo isso, é evidente que o infeliz acontecimento com o menino citado nos artigos ocorreu em local onde se praticam magia negra, macumba ou outros nomes que se queiram dar, mas nunca numa sessão espírita, como dá conta a primeira reportagem. Antonio de Paiva Meio, presidente da Federação Espírita do Estado do Rio de Janeiro - Rio de Janeiro". (Jornal do Brasil de 18 de janeiro de 1980). ${ }^{2}$

Os espíritas defendem-se distinguindo-se de religiões que adotam "ritual", fazem "sacrifícios" para "abrir caminhos", onde há "pais-de-santo", "cambonos", dos "cultos fetichistas", da "magia negra" ou "macumba".Passando de acusado a também acusador,

\footnotetext{
${ }^{1}$ Nesse estigma está em jogo entre outras coisas a visão dos fenômenos mediúnicos como ameaçadores e de alguma forma subversivos da ordem.

${ }^{2}$ Ver também O Globo, de 28 de outubro de 1979, Caderno de Domingo: "Interesses Pessoais é que levam ao Fanatismo", O Globo de 30 de janeiro de 1980, Caderno de Domingo: "A Religião Violenta", e o Mundo Espírita de 31 de janeiro de 1980, carta da p. 10.
} 
enfatiza-se não só o caráter próprio do Espiritismo Como sua vertente cristã. Essa é, de maneira geral, a resposta junto ao grande público, na qual se evidencia uma preocupação de legitimação do Espiritismo com relação à sociedade maior. ${ }^{3}$

$\mathrm{Na}$ vivência dos grupos pesquisados a questão torna-se mais complexa. Algumas pessoas entrevistadas por mim eram de procedência umbandista. Tinham parentes próximos ou amigos umbandistas. As que não provinham da Umbanda, em sua maior parte ex-católicos, já tinham ido uma ou outra vez a um terreiro. Em ambos os casos a freqüência atual a terreiros era negada.

Aos olhos espíritas, é o fato de a Umbanda aceitar a comunicação com os Espíritos o que a aproxima do Espiritismo. A comunicação com os Espíritos é uma das verdades fundamentais do Espiritismo, a qual é compartilhada pela Umbanda. Reconhece-se na Umbanda essa verdade. Essa relação e essa verdade reconhecidas são lidas à luz dos princípios que ordenam o Espiritismo - a hierarquia, a evolução, a oposição materialespiritual. O potencial explicativo da doutrina espírita é capaz de dar conta, evidentemente na sua perspectiva, das crenças e práticas umbandistas. O Espiritismo é pensado como mais espiritual, mais evoluído. Como me disse um informante:

Na Umbanda, os Espíritos que fazem a manifestação não é que sejam menos poderosos, é que são mais simples. A idéia de Bem e de Mal talvez não esteja neles desenvolvida. Para ter essa idéia é preciso ter a idéia do Bem absoluto. Se você não a tiver, vai ter a do Bem relativo: o que é bom para você pode ser mau para mim. A Umbanda tem essa idéia de Bem relativo, limitado. E cai, como no caso do Exu, no paradoxo de fazer Bem a um e Mal a outro. Não há codificarão. Mas há Espíritos como o Preto Velho e o Caboclo, que não são maus, mas simples.

Essa identificação da Umbanda com o mais material e menos evoluído, inferior em suma, é fonte de objeções por parte dos umbandistas, que criticam, nas palavras de uma médium de Umbanda, o elitismo e o orgulho dos espíritas. Essa inferioridade, porém, não é absoluta, Do ponto de vista espírita, a superioridade absoluta é inatingível para os homens, é Deus. A humanidade é por definição imperfeita, são Espíritos em evolução. Se é possível distinguir entre os mais e menos evoluídos, são todos na Terra imperfeitos e nesse sentido inferiores. Se é possível aos espíritas qualificar a Umbanda e conseqüentemente os umbandistas como menos evoluídos, é preciso lembrar simultaneamente a imperfeição e inferioridade própria. Alguns atributos de entidades da Umbanda são assim especialmente valorizados:

\footnotetext{
${ }^{3}$ Realizações como o lançamento da candidatura de Chico Xavier ao Prêmio Nobel da Paz (Folha Espírita, n84, março de 1981) e o programa "Chico Xavier, um Homem chamado Amor", apresentado pela TV Globo na série "Sexta-Super" (23 de maio de 1980), corroboram essa preocupação.
} 
Todos temos nosso Preto Velho, que tem uma grande virtude, a humildade. O Preto Velho é um Espírito que parou numa encarnação. As pessoas ficam aí falando de Espírito de Luz, da Verdade, e o Preto Velho é melhor do que muitos porque tem a humildade.

A combinação entre Espiritismo e Umbanda é assim vista como perfeitamente possível:

Se você parte da idéia de que em ambos existe a manifestação dos Espíritos, é uma questão de oferecer os elementos físicos para a Umbanda. Há na Umbanda Espíritos que podem ser carreados apenas para o Bem Pode trabalhar com essas falanges. No Tupyara, certamente eles discernem. Criam as coisas de modo a não permitir certas coisas. Tem Umbanda, mas com a parte doutrinária.

Ou ainda:

Agora lá (referia-se ao Tupyara) tem Um banda. E daí? Lá usam roupa branca.Roupa branca também é limpeza. Se fazem trabalho de cura bom, tudo bem.Lá tem Umbanda, Umbanda tem rituaL Então tem que usar roupa branca mesmo.Hospital também não usa? Os Espíritos vão aos centros que agradam a eles. Se gostam vão lá. Não deixam de ser Espíritos por isso. Se forem bons...O Preto Velho faz muita coisa boa. Tem tanto ou mais poder do que os outros.Às vezes ele consegue dominar melhor o obsessor do que o Espírito iluminado.O obsessor vê mais ele. O juiz não manda o homem que tem força prender o bandido?

Perguntei a essa informante se havia então casos em que a pessoa era mandada a um terreiro de Umbanda. Ela respondeu-me que não, o Preto Velho era recebido no próprio centro.

De fato, os Espíritos da Umbanda, vistos como Espíritos de determinada ordem da hierarquia espiritual, em evolução como todos os demais, comparecem em algumas sessões espíritas. A incorporação desses Espíritos pode ser vista como uma forma de reflexão e elaboração da relação com a Umbanda. Antes de mais nada é preciso que eles (os Espíritos da Umbanda) "aceitem a disciplina da casa", ou seja, submetam-se à incorporação como o Espiritismo a concebe e valoriza. Numa das sessões, um médium chamado Edivar, bastante gago e que quando em transe falava fluentemente, incorporou um Espírito que dizia:

É preciso coragem, hum! hum! Eu venho de outras seitas, hum! hum! Ainda não sou de muita luz, hum! hum!

Na parte final da sessão outro médium comentou que naquele momento lhe viera à mente a pergunta: "Onde estão os atabaques?" O Espírito foi identificado como sendo um Preto Velho. Numa sessão de desobsessão, uma médium recebeu um Espírito que dizia:

Ué, onde estou? O que eu vim fazer aqui? Não é aqui o lugar que eu venho! Não é daqui que eu gosto! 
O doutrinador lhe dizia:

Se você está aqui é porque os amigos espirituais o trouxeram aqui para ajudá-lo.

O Espírito identificou-se como um freqüentador de terreiros e dizia:

Aqui é muito complicado. Eu gosto é de lá que eu peço as coisas e eles me dão tudo direitinho, galinha, cigarro... E aqui? O que vocês têm para me dar?

O doutrinador respondeu:

Olhe, nós temos a nossa boa vontade, a nossa ajuda. Se você veio aqui é porque já está no momento de aprender a discernir entre o bem e o mal. Olhe, aqui está um retrato que eu tenho para lhe dar (tratava-se de uma imagem espiritual).

O Espírito:

É uma porção de carneirinhos.

O doutrinador:

É, é Jesus com suas ovelhas. Você é uma delas.

Espírito:

Ah! Ele vai saber o mal que eu pratiquei. Mas eu não faço mal muito grande não. Faço mal pequeno, coisa à toa.

Bruno:

Mas, meu filho, se você não faz o bem, já faz o mal. Eu estou vendo seu coração. Você é bom.

\section{Espírito:}

Ah! Mas eu sou boa-vida. Eu gosto é de dá onde eles me dão o que peço.

O diálogo prosseguiu ainda um pouco. Ao final o Espírito disse que até que lá não era tão ruim assim. O doutrinador respondeu-lhe dizendo que voltasse quando quisesse e pudesse.

Era comum também o relato de sonhos nos quais apareciam entidades de Umbanda como um em que a médium se lembrava de que

vinha um Espírito, não me lembro bem o nome, é um desses nomes de Umbanda, Sete não sei das quantas, que dizia: "Olhe, eu vim de muito longe para trazer-lhe isso. Isso não sei o quê"... 
Ou ainda a existência de amigos espirituais negros e índios que lembram as entidades do Caboclo e do Preto Velho.

A relação entre Espiritismo e Umbanda ancora-se assim em características estruturais dos dois sistemas. O eixo de aproximação é a comunicação espiritual, a experiência da Mediunidade, a presença e a força dos Espíritos em ambas as religiões e o papel decisivo atribuído a estes na compreensão do mundo humano. Todavia, a maneira diversa pela qual essa experiência se dá era assinalada pelos espíritas como importante:

A Umbanda desenvolve um tipo de mediunidade inconsciente. O Espírito faz o que bem entende com o médium, que é o cavalo. Ora, o animal é dirigido, não tem vontade própria. Rola, cai. Não que no Espiritismo isso não ocorra.Pode ser se você tem um Espírito que obsidia as pessoas. Chega lá, dá-lhe uma derrubada no chão. Mas não é o normal...

Lá o Espírito faz da gente gato e sapato e a gente se deixa levar pelo Espírito. A gente faz mas não sabe por quê. A passividade é completamente diferente.

Ou ainda:

Eu recebia e o Espírito vinha e quebrava mesa. Uma vez tirei os sapatos e joguei longe. Depois eu ficava morrendo de vergonha. Hoje em dia controlo. Sinto que o irmaõzinho está com vontade mas eu seguro.

Se a mediunidade aproxima, a maneira particular de sua efetivação, relacionada ao conjunto de cada um desses sistemas, os diferencia nitidamente. A possessão, entendida como perda de controle do homem sobre suas ações, que passam a ser governadas pela entidade incorporada, é uma possibilidade presente em ambos os sistemas. A atitude com relação a ela, porém, diverge bastante. A experiência da mediunidade nos rituais da Umbanda é possessão. ${ }^{4} \mathrm{O}$ sistema ritual espírita comporta, como vimos, diversas formas de experiência da mediunidade. A incorporação de Espíritos é apenas uma delas. E a incorporação não é possessão. Ela funciona, entre outras coisas, como vimos no ritual da desobsessão, como uma forma de rechaçar essa terrível e possível ameaça de aniquilamento do livre-arbítrio humano que a obsessão atualiza cotidianamente. $\mathrm{Na}$ incorporação, o visível e o invisível se relacionam de maneira ordenada de modo a garantir a disjunção dos mundos e o exercício do livre-arbítrio humano. A possessão o aniquilamento do livre-arbítrio, a perda de controle sobre o próprio corpo - é vista no Espiritismo como extremamente perigosa. Nos termos de Mary Douglas (op. cit.) o Espiritismo corresponde a uma estrutura social que exige o controle do comportamento individual.. A meu ver, o Espiritismo é antes uma experiência social na qual se produz e se

\footnotetext{
4 Ver a esse respeito Yvonne Velho, 1975.
} 
problematiza um determinado comportamento individual. Pois é exatamente a concepção distinta do que seja o "comportamento individual", do que seja o indivíduo portador de seu comportamento, o que distingue, entre outras coisas, o Espiritismo da Umbanda. A experiência da mediunidade no Espiritismo remete à concepção da pessoa nessa religião.

A pessoa é o ponto de convergência de todo esse sistema. Como o Espiritismo a concebe, ela é uma reunião de três elementos - o corpo, o perispírito e o espírito - que se organizam numa hierarquia do mais espiritual $=$ eterno ao mais material $=$ mortal. Nela, os dois eixos que ordenam a relação entre os mundos se cruzam. No eixo da diacronia, o jogo entre o livre-arbítrio do Espírito e o determinismo divino produz a oposição Eu maior x Eu menor, a fragmentação da identidade nos Estados de Espírito encarnado, errante e puro. No eixo da sincronia, o permanente confronto do livre-arbítrio humano, por definição incompleto, com livres-arbítrios mais ou menos poderosos gera uma tensão entre urna imagem de homem como instrumento relativamente passivo dos Espíritos, e do homem como guardando sua individualidade. No estudo e na caridade, o homem se fortalece como individualidade. Na mediunidade essa tensão emerge com toda a força. A obsessão atualiza a possibilidade de possessão, de aniquilamento do livre-arbítrio humano e representa, como vimos, urna

antiencarnação, um congelamento da evolução. No ritual da desobsessão, o livre-arbítrio humano, derrotando o livre-arbítrio do Espírito inferior desencarnado, garante a medida de seu exercício, devolve à encarnação o seu sentido, restabelece o progresso e a evolução, a transcendência da matéria pelo espírito.

Em sua formulação Camargo (Camargo, op. cit.) aponta uma questão crucial, a do lugar da experiência da mediunidade na relação que as religiões que a promovem mantêm entre si. Tomando essa experiência como central, Camargo toma-a também como comportando sempre o mesmo conteúdo, identificando apenas "diferenças de estilo e ênfase" (Camargo, 1961: 83). A experiência da mediunidade transforma-se na base de um continuum que abrange formas religiosas cujos pólos são Kardecismo e Umbanda. Kardecismo e Umbanda distinguem-se pelos qualificativos opostos consciente $\mathrm{x}$ inconsciente, racional x emocional, ético x mágico. Camargo percebe a relação entre essas religiões como uma relação de continuidade a partir de categorias que são externas às formas religiosas em questão.A meu ver, a relação entre Espiritismo e Umbanda deve ser pensada a partir das características internas a esses sistemas religiosos. No que tange ao Espiritismo, essa relação se funda no reconhecimento e na afirmação da mediunidade implicando descontinuidades e diferenças na maneira de conceber e resolver o contato 
entre homens e Espíritos. A experiência mediúnica, reconhecida como central em ambas as religiões, ganha em cada uma delas formas qualitativamente distintas, que envolvem, como procurei demonstrar no caso do Espiritismo, concepções particulares do que seja a pessoa humana e do mundo em que ela existe. 


\title{
BIBLIOGRAFIA CITADA
}

\author{
Amorim, Deolindo \\ [s/d] O Espiritismo e as Doutrinas Espiritualistas. S. Paulo, Livraria Chignone Ed. \\ Bastide, R. \\ 1971 As Religiões Africanas no Brasil. S. Paulo, Pioneira. \\ 1972 Le Rêve, la Transe et la Folie. Paris, Flammarion. \\ Bateson, G. \\ 1965 Naven. Califórnia, Stanford University Press. \\ Berofsky, B. \\ 1973 "Free will and determinism", in Dictionary of Ideas: Studies of Selected Pivotal \\ Ideas. Nova York, Ed. in chief Philip Wiener, Charles Scribner Sons, vol. 3. \\ Birman, $\mathbf{P}$. \\ 1980 Feitiço, Carrego e Olho Grande, os Males do Brasil São (mimeog.). Dissertação de \\ mestrado apresentada ao Programa de Pós-Graduação em Antropologia Social, Museu \\ Nacional.
}

Bourguignon, E.

1973 Religion, Altered States of Consciousness and Social Change. Ohio, Ohio State University Press.

Brown, D.

1974 Umbanda: Politics ofan Urban Religious Movement (mimeog.).

Brito Soares

1962 Vida e Obra de Bezerra de Menezes. FEB.

Camargo, C.P.

1961 Kardecismo e Umbanda. S. Paulo, Pioneira.

1973 Católicos. Protestantes e Espíritas. Petrópolis, Vozes.

Comte, A.

1973 "Curso de Filosofia Positiva", in Os Pensadores, vol. XXIII. S. Paulo, Abril Cultural. Conan Doyle

[s/d] A História do Espiritismo. S. Paulo, Pensamento.

Da Matta, R.

1978 O Oficio do Etnólogo ou como Ter Anthropological Blues, in Boletim do Museu Nacional, $\mathrm{n}^{\circ}$ 27, Rio de Janeiro.

1979 Carnavais, Malandros e Heróis. Rio, Zahar.

Dodds, E.R.

1951 The Greeks and the Irrational. Berkeley, University of California

Press.

Douglas, $M$.

1966 Pureza e Perigo. S. Paulo, Perspectiva.

1970 Natural Symbols. Londres, Barrie \& Rockcliff, The Cresset Press.

Duarte, L.F.

1980 "O Culto do Eu no Templo da Razão" (dat.). PPGAS/Museu Nacional.

Dumont, L.

1966 "Vers une théorie de la hierarchie", in Homo Hierarchicus. Paris, Gallimard.

1978 "Genèse de l'individualisme occidental", in Esprit, fev.

Durkheim E.

1968 Las Formas Elementales de la Vida Religiosa. B. Aires, schapire.

Evans-Pritchard, E. 
1972 Sorcellerie, Oracles et Magie chez les Azande. Paris, Gallimard. [Ed. brasileira: Bruxaria, Oráculos e Magia entre os Azande. Rio, Zahar, 1978]

Firth, R.

1967 Tikopia, Ritual and Belief. Londres, Allen \& Unwin.

Fry, P. \& Howe, G.N.

1975 "Duas respostas à aflição: Umbanda e Pentecostalismo", in Debate e Crítica, no 6.

Geertz, C.

1978 A Interpretação das Culturas. Rio, Zahar.

Gernet, L.

1976 Anthropologie de la Grèce antique. Paris, Maspero.

Gilson, E.

1978 L 'Esprit de la Philosophie Médievale. Paris, J. Vrin.

Goldman, $M$.

1982 "A Construção Ritual da Pessoa: a Possessão no Candomblé" (dat.). Trabalho apresentado no VI Encontro da Associação Nacional de Pós-Graduação e Pesquisa em Ciências Sociais, Friburgo.

Gluckman, $M$.

1962 Essays on the Ritual of Social Relations. Manchester University Press.

Hoskins, J.

1975 Patterns of Trance and Social Order. Senior Thesis (mimeog.).

Jean-Maire, $H$.

1970 Dionysos, Histoire du Culte de Bacchus. Paris, Payot.

Kardec, Allan.

1970 O Livro dos Espíritos. Núcleo Espírita Caminheiros do Bem.

1978 O Livro dos Médiuns. Núcleo Espírita Caminheiros do Bem.

1975 O Evangelho segundo o Espiritismo. FEB.

1979 A Gênese, os Milagres, as Predições. FEB.

1978 O Céu e o Inferno. FEB.

Kloppenburg, B.

1961 O Reencarnacionismo no Brasil. Petrópolis, Vozes.

Leach, E.

1971 "La Ritualisation chez l'homme par rapport à son développement culturel et social", in Le Comportement rituel chez l'homme et l'animal. Paris, John Huxley, Gallimard.

1972a "Ritual", in International Encyclopedia of Social Sciences, vol. 13/14. The Macmillan Company \& The Free Press, Nova York, Collier-Macmillan Publishers, Londres.

1972b Les systemes politiques des haures terres de Birmanie. Paris, Maspero.

Lévi-Strauss, $\mathbf{C}$.

1971 L 'Homme Nu. Mitologiques IV. Paris, Plon.

1976 Antropologia Estrutural II. Rio, Tempo Brasileiro.

1977 L'ldentité. Seminaire dirigé par Claude Lévi-Strauss. Paris, Bernard Grasset.

1978 "Introduction à I'ceuvre de Marcel Mauss", in M. Mauss Sociologie et Anthropologie. Paris, PUF.

Lewis, I.

1971 O Êxtase Religioso. S. Paulo, Perspectiva.

Lossio, Z.

1979 Dentro de um Ponto Riscado (mimeog.). Dissertação de Mestrado, Programa de PósGraduação em Antropologia Social Museu Nacional.

1980 "Servo e Senhor: Notas sobre o trabalho de campo na área da religião", in O Desafio da Cidade. Gilberto Velho (org.). Rio, Campus. 
Marx, K. \& Engels, F.

1972 La ideología Alemana. Barcelona, Ed. Grijalbo.

Mauss, Marcel

1978 "Essai sur le don"; "Rapports Réels et Pratiques de la Psychologie et de la Sociologie" e "Une catégorie de I'Esprit Humain: la notion de Persoime, celle du moi", in Sociologie et Anthropologie. Paris, PUF.

Mauss, M. \& Hubert, Henri

1968 "Essai Sur Ia nature et Ia fonction du sacrifice", in M. Mauss, OEuvres, vol.1.Paris, Ed. de Minuit.

\section{Nina Rodrigues}

1900 L'Animisme, Fetichiste des Negres de Bahia. Salvador, Reis e Cia.

Pereira, Yvone*

1976 Recordações da Mediunidade. FEB.

Pressel, E.

1974 "Umbanda trance and possession in São Paulo", in Trance, Healing and Allucination: Three Field Studies in Religious Experience. Londres, John Wiley Sons.

\section{Radc1iffe-Drown}

1973 Estrutura e Função na Sociedade Primitiva. Petrópolis, Vozes.

\section{Renshaw, Parke}

1969 A Sociologicol Analysis of Spiritism in Brazil (mimeog.). Dissertation presented to the Graduate Council of The University of Florida, University of Florida.

1975 Rising with the Spirits: Spiritism and Umbanda as Related to Social Mobility in Industrialing Brazil. American Anthropological Association (mimeog.).

Simmel, G.

1977 "El Pobre", in Sociología 2. Estudios sobre las formas de socialización. Madri, Biblioteca de Ia Revista de Occidente.

\section{Skorupski, J.}

1976 Symbol and Theory: a Philosophicol Study of Theories of Religion in Social Anthropology. Cambridge, Cambridge University Press.

Smith, R.

1972 The Religion of the Semites. Nova York, Schocher Dooks.

Soares, L.E.

1979 "O autor e seu Duplo", in Religião e Sociedade, nº 4. Rio, Civilização Brasileira.

Sperber, Dan

1974 Le Symbolisme en géneral. Paris, Heman.

\section{Spiro, Melford}

1971 Buddhism and Society: a Great Tradition and its Burmese Vicissitudes. Londres, George AIlen \& Unwin.

Timponi, Miguel

[s/d] A Psicografia perante os Tribunais. FED.

Tylor, E.B.

1970 The Origins of Culture. Gloucester, Peter Smith.

\section{Turner, V.}

1967 The Forest of Symbols. Londres, Cornell University Press.

1973 "Symbols in African Ritual", in Science, 16/03, vol. 179.

Velho, G.

1975 Nobres e Anjos: Um Estudo de Tóxicos e Hierarquia (mimeog.). Tese de doutorado apresentada à USP.

1980 "O antropólogo pesquisando em sua cidade: sobre conhecimento e heresia", in $O$ Desafio da Cidade. Velho, G. (org.). Rio, Campus. 
1981 Individualismo e Cultura. Rio, Zahar.

Velho, Y. Maggie

1975 Guerra de Orixá: Um Estudo de Ritual e Conflito. Rio, Zahar.

Vernant, J,P.

1973 Mito e Pensamento entre os Gregos. S. Paulo, Difel.

1977 As Origens do Pensamento Grego. S. Paulo, Difel.

Vieira, Waldo \& Xavier, Francisco Cândido *

1978 Palavras de Vida Eterna. Pelo Espírito Emmanuel. CEC.

1969 Desobsessão. Pelo Espírito André Luiz. FEB.

Warren Jr, D.

1968a "Spiritism in brazil", in Journal of Inter-American Studies, vol. 10.

1968b "Portuguese roots of Drazilian Spiritism", in Luso-Brazilian Review, vol. V, no 2. Wisconsin, The University of Wisconsin Press.

Weber, Max

1967a Ancient Judaism. Nova York, The Free Press.

1967b A Ética Protestante e o Espírito do Capitalismo. S. Paulo, Pioneira.

1974 "Sociología de la Religión", in Economía y Sociedad. México, Fondo de Cultura Económica.

Xavier, Francisco Cândido*

1944 Os Mensageiros. Pelo Espírito André Luiz. FED.

1947 No Mundo Maior. Pelo Espírito André Luiz. FED.

1948 Caminho, Verdade e Vida. Pelo Espírito Emmanuel. FEB.

1949 Libertação. Pelo Espírito André Luiz. FED.

1956 Fonte Viva. Pelo Espírito Emmanuel. FED.

1960 A Conduta Espírita. Pelo Espírito André Luiz. FEB.

\section{Jornais e Publicações}

Anais do Instituto de Cultura Espírita do Brasil, vols. III e IV. Rio de Janeiro, 1979.

A Folha Espírita. Março de 1981.

Jornal do Brasil, de 18 de janeiro de 1980.

O Globo, de 28 de outubro de 1979 e de 30 de janeiro de 1980.

O Mundo Espírita, janeiro de 1980.

Orientação aos Centros Espíritas. FEERJ, 1980.

Apostilas sobre Mediunidade (dat.).

* Todos os nomes assinalados pelo asterisco são de médiuns psicógrafos. Os verdadeiros autores nesses casos seriam os Espíritos. 